\title{
Teaching leadership development at the secondary level: A national study
}

\author{
Nathan Taylor \\ West Virginia University
}

Follow this and additional works at: https://researchrepository.wvu.edu/etd

\section{Recommended Citation}

Taylor, Nathan, "Teaching leadership development at the secondary level: A national study" (2006). Graduate Theses, Dissertations, and Problem Reports. 2461.

https://researchrepository.wvu.edu/etd/2461

This Thesis is protected by copyright and/or related rights. It has been brought to you by the The Research Repository @ WVU with permission from the rights-holder(s). You are free to use this Thesis in any way that is permitted by the copyright and related rights legislation that applies to your use. For other uses you must obtain permission from the rights-holder(s) directly, unless additional rights are indicated by a Creative Commons license in the record and/ or on the work itself. This Thesis has been accepted for inclusion in WVU Graduate Theses, Dissertations, and Problem Reports collection by an authorized administrator of The Research Repository @ WVU. For more information, please contact researchrepository@mail.wvu.edu. 
Teaching Leadership Development at the Secondary Level: A National Study

Nathan Taylor

Thesis Submitted to the Davis College of Agriculture, Forestry, and Consumer Sciences at West Virginia University in partial fulfillment of the requirements for the degree of

Master of Science

in

Agricultural and Environmental Education

Deborah A. Boone, Ph.D., Chair

Harry N. Boone, Jr., Ph.D.

Stacy A. Gartin, Ph.D.

Division of Resource Management

Morgantown, West Virginia

2006

KEYWORDS: AGRICULTURAL EDUCATION, FFA, LEADERSHIP, TRAINING 


\author{
ABSTRACT \\ Teaching Leadership Development \\ at the Secondary Level: A National Study
}

Nathan Taylor

The purpose of this study was to determine the importance of different leadership skills taught to agriculture students and FFA members at the chapter level, where students and members receive leadership training, the frequency of training, and identify the instructors that provide leadership training. This study was a descriptive survey research conducted with agricultural science instructors who serve as FFA advisors of chapters recognized in the National Chapter Awards Program at the $78^{\text {th }}$ National FFA Convention. The 10 most important skills identified by agriculture science teachers were (in order of importance); teamwork, opportunities in FFA, being responsible, setting personal or team goals, commitment, being a role model in your chapter, cooperation, ethical leadership, solving problems, and effective listening. Running an effective meeting, motivating members, qualities of an influential leader, delivering a speech, and planning an activity were taught by all agricultural science teachers in the study. 


\section{ACKNOWLEDGEMENTS}

To the high school agriculture teachers and FFA advisors who were giving of their time and thoughts which allowed for the completion of this research project.

To the members of my graduate committee:

Dr. Deborah A. Boone for her attention to detail and having such a positive attitude to guide me through this research.

Dr. Harry N. Boone Jr. for his impeccable skill as a statistician and researcher.

Dr. Stacy A. Gartin for his ability as a motivator to help me through my graduate studies.

To my family for being there on the phone while I was away from home for so long.

To my friends for being a necessary escape from reality when needed. 


\section{TABLE OF CONTENTS}

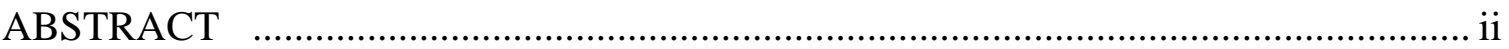

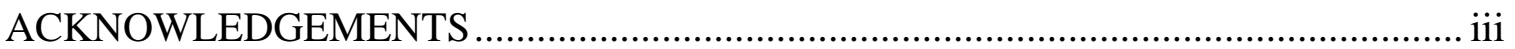

TABLE OF CONTENTS ......................................................................................... iv

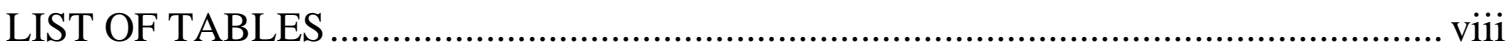

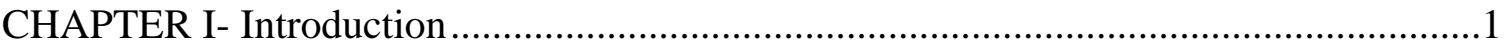

Statement of Problem..................................................................................

Purpose of Study …………………….............................................................

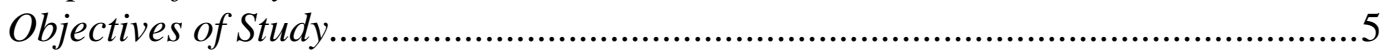

Limitations to the Study ...................................................................................

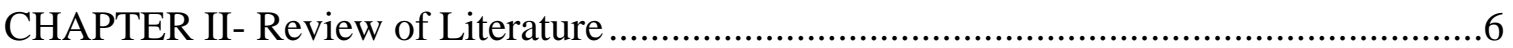

Historical Overview of Federal Vocational Education Legislation .........................6

Historical View of Components of High School Agricultural Science

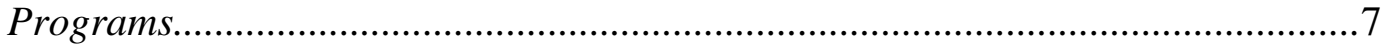

Leadership Defined .........................................................................................10

Leadership Abilities Increase From Involvement in FFA......................................11

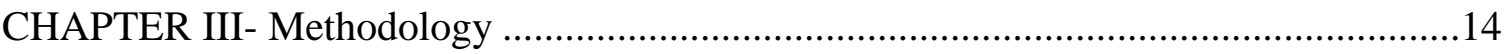

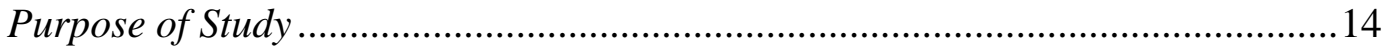

Objectives of the Study …………………………….........................................14

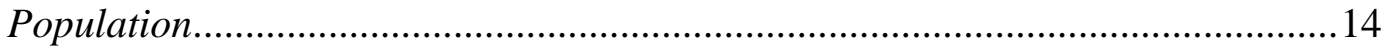

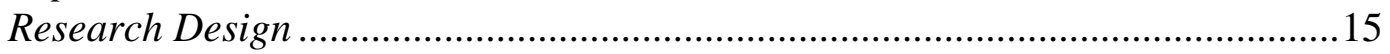

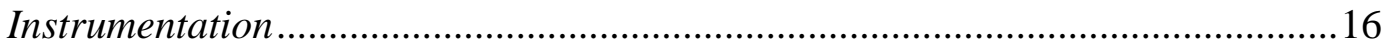

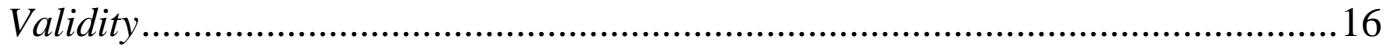

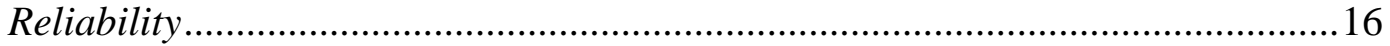

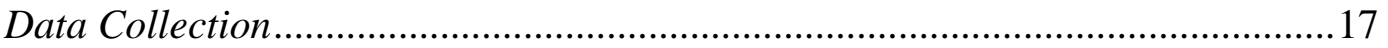

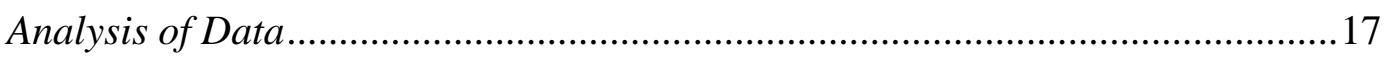

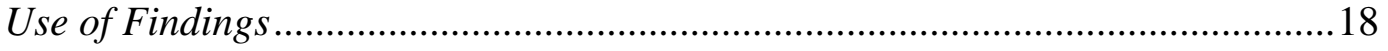

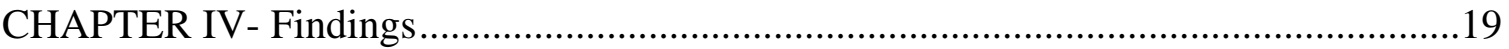

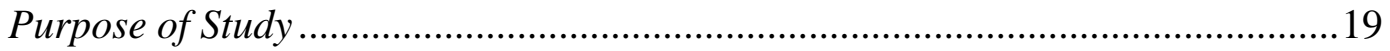

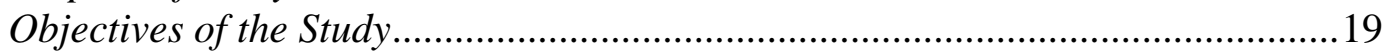

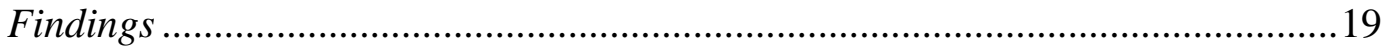

Demographic Characteristics of Respondents..................................................22

Years Teaching Experience..................................................................................21

Importance, Frequency, and Location of Instruction of Appearance Skills..........22

Professional dress ................................................................................22

Personal hygiene and attire ..................................................................24

Utilizing proper travel etiquette..............................................................25

Using proper dining etiquette ....................................................................25 


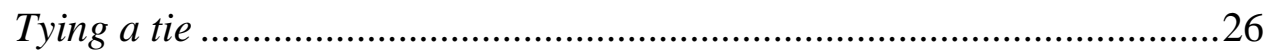

Importance, Frequency, and Location of Instruction of Creative Thinking

Skills

Creating executive meetings that your fellow officers will not want

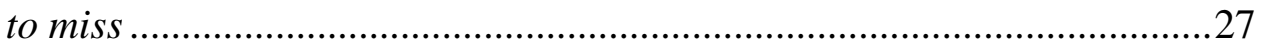

Banquet ideas that work..........................................................................31

Great meeting activities-mixers, icebreakers, energizers...........................31

Enhancing your creativity.......................................................................32

Generating great ideas for skits, meeting activities, and

presentations .............................................................................................33

Creating super slide shows .......................................................................33

Importance, Frequency, and Location of Instruction of Educational

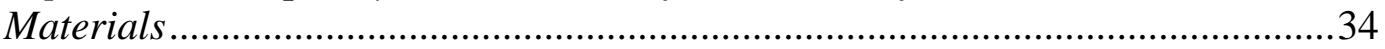

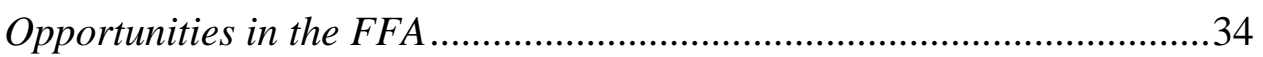

Agriculture Issues ......................................................................................

Organizational structure.....................................................................38

Agricultural education issues ...............................................................38

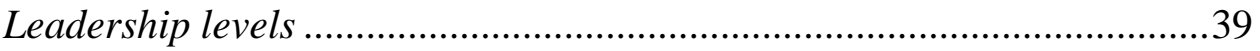

Leadership styles..................................................................................40

Learning styles ......................................................................................40

Importance, Frequency, and Location of Instruction of Leadership Ability

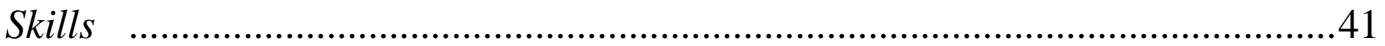

Being a role model in your chapter ..........................................................41

Motivating members....................................................................................4

Practicing proper parliamentary procedure ...............................................48

Creating partnerships with community and industry leaders.....................49

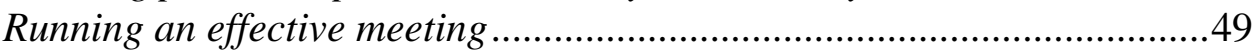

Encouraging others................................................................................50

Delegating so that the work gets done ......................................................50

Leading an activity .............................................................................51

Expressing your opinion so that others listen...........................................52

Facilitating a meeting or discussion.........................................................52

Characteristics of an effective team player ...............................................53

Utilizing situational leadership.................................................................53

Qualities of an influential leader ............................................................54

Dealing with difficult members at your meetings .......................................55

Types and uses of power ...........................................................................55

Importance, Frequency, and Location of Instruction of Oral

Communication Skills ......................................................................................56

Delivering a speech............................................................................56

Giving clear directions ..........................................................................62

Presenting powerful ceremonies...............................................................62

Developing and delivering powerful key messages ...................................63

Utilizing effective telephone etiquette........................................................63

Using audio-visual equipment in your presentations .................................64

Establishing and maintaining conversations ..............................................65 
Introducing a speaker .............................................................................65

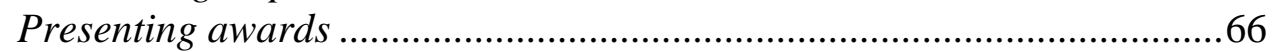

Creating welcoming remarks..............................................................66

Using a microphone effectively..................................................................67

Importance, Frequency, and Location of Instruction of Personal Skills................67

Being responsible..................................................................................67

Effective listening ................................................................................75

Improving self confidence .....................................................................76

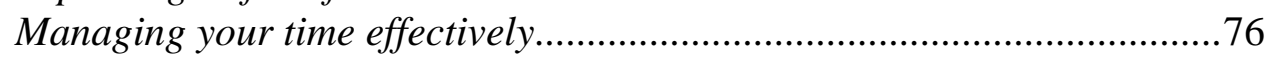

Creating a great first impression ................................................................77

Relationship building ............................................................................77

Managing your life............................................................................

Accepting constructive criticism ...............................................................78

Keys to personal success.........................................................................79

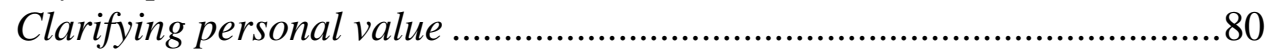

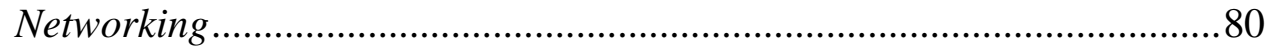

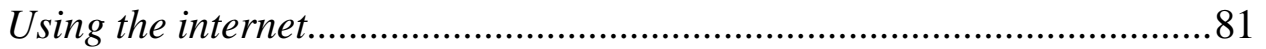

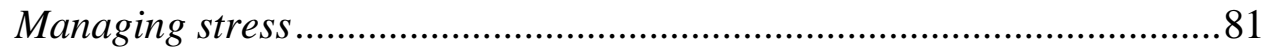

Shaking hands the proper way ...................................................................82

Communicating without words (non-verbal).............................................82

Remembering names ..............................................................................83

Importance, Frequency, and Location of Instruction of Planning \&

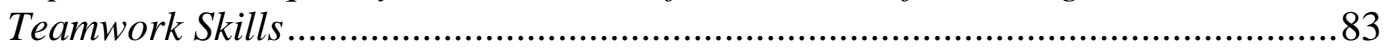

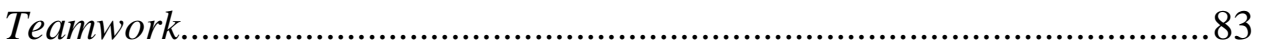

Setting personal or team goals ................................................................8

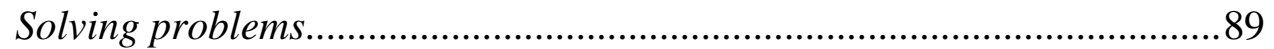

Setting priorities........................................................................................99

Resolving conflict on your team or in your chapter ...................................90

How to build a powerful team....................................................................91

Planning an activity .............................................................................91

Developing a program of work.............................................................92

Creating a budget .....................................................................................93

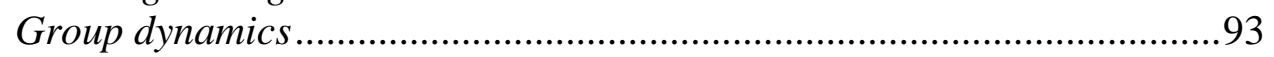

Writing team or individual mission statements..........................................94

Importance, Frequency, and Location of Instruction of Leadership

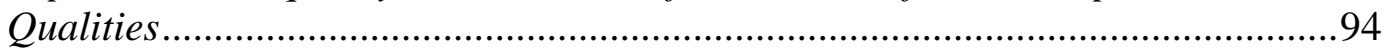

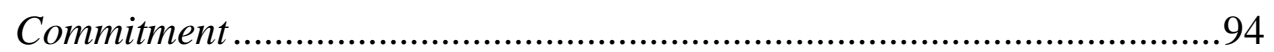

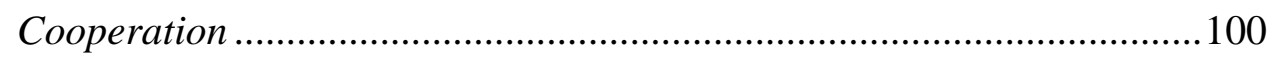

Ethical leadership ……………………................................................101

Maintaining a positive attitude ..............................................................102

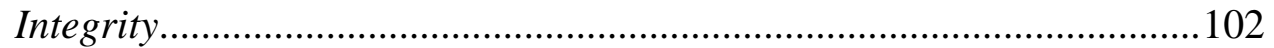

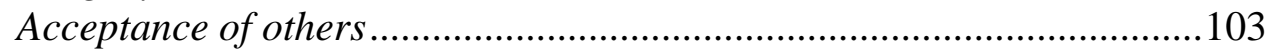

Lifelong learning ..................................................................................103

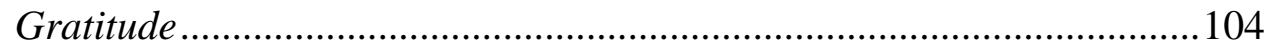

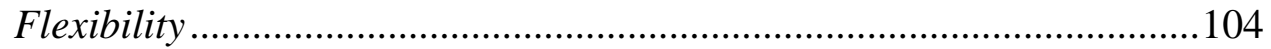

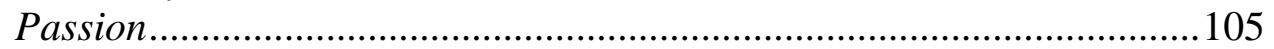




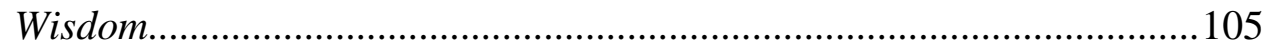

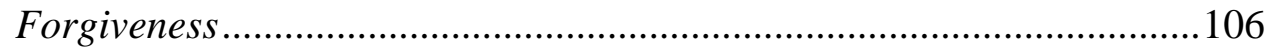

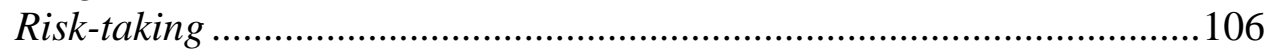

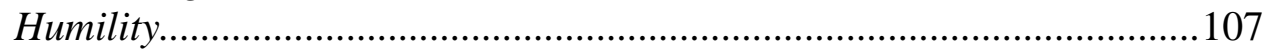

Importance, Frequency, and Location of Instruction of Written

Communication Skills .....................................................................................107

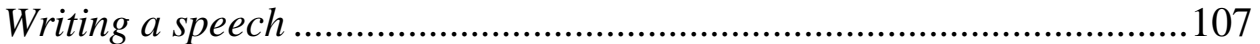

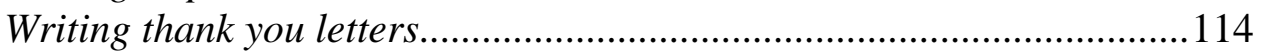

Getting local newspapers to publish your news releases ........................115

Writing news releases .............................................................................115

Writing business letters.........................................................................116

Creating PowerPoint presentations........................................................117

Writing meeting minutes .......................................................................117

Making handouts for your presentations .................................................118

Taking great photographs...................................................................118

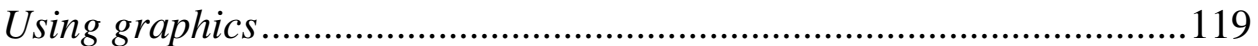

Writing committee reports .....................................................................119

Creating an awesome scrapbook ...........................................................120

Designing attractive web pages ...............................................................121

Writing a workshop ..............................................................................121

Sources of Leadership Training Assistance ..........................................................122

CHAPTER V- Summary, Conclusions, and Recommendations .......................................124

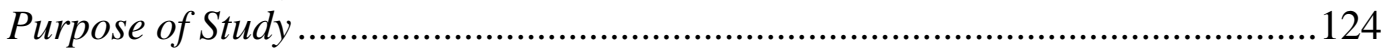

Objectives of the Study ................................................................................124

Summary of Findings ...................................................................................124

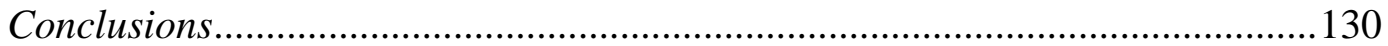

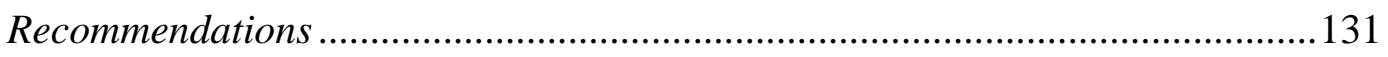

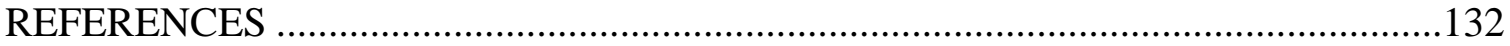

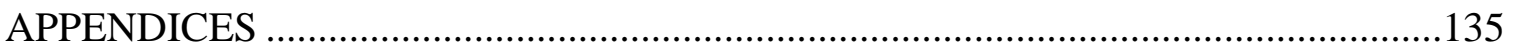

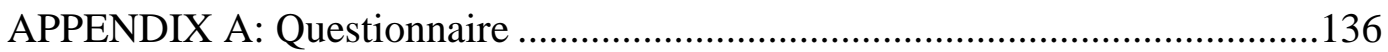

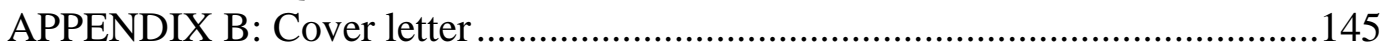

APPENDIX C: Follow-up cover letter ............................................................147

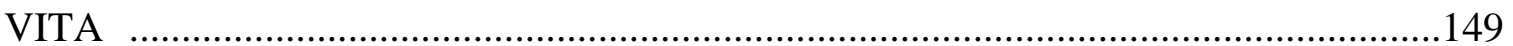




\section{LIST OF TABLES}

Table Title Page

$1 \quad$ Demographic Characteristics of Respondents...........................................21

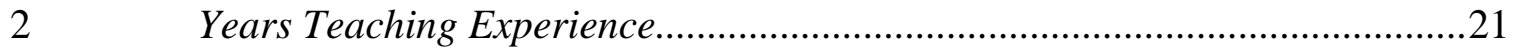

3 Importance \& Frequency of Appearance Qualities......................................22

$4 \quad$ Location Where Appearance Qualities Skills are Taught..............................23

$5 \quad$ Importance \& Frequency of Creative Thinking Skills ....................................28

$6 \quad$ Location Creative Thinking Skills are Taught ............................................29

$7 \quad$ Importance \& Frequency of Educational Materials Skills .............................35

$8 \quad$ Location Educational Materials Skills are Taught......................................36

$9 \quad$ Importance \& Frequency of Leadership Ability Skills .................................42

$10 \quad$ Location Leadership Abilities are Taught ................................................44

$11 \quad$ Importance \& Frequency of Oral Communication Skills ...............................57

$12 \quad$ Location Oral Communication Skills are Taught..........................................58

13 Importance \& Frequency of Personal Skills.............................................68

$14 \quad$ Location Personal Skills are Taught........................................................ 70

15 Importance \& Frequency of Planning \& Teamwork Skills ............................84

$16 \quad$ Location Planning \& Teamwork Skills are Taught ......................................85

17 Importance \& Frequency of Leadership Qualities Skills ..............................95

$18 \quad$ Location Leadership Qualities are Taught ..............................................96

19 Importance \& Frequency of Written Communication Skills.........................109

$20 \quad$ Location Written Communication Skills are Taught ...................................110

$21 \quad$ Sources of Leadership Training Assistance ..............................................123 


\section{CHAPTER I}

\section{Introduction}

Bernthal and Wellins (2003) in their Leadership Forecast 2003, concluded "It’s harder to be a leader today and the pressure is building” (p. 5). Their study included over 3100 business leaders, associates, and human relations representatives from 14 countries around the world. Their study found that the majority of the organizations represented do not have high levels of confidence in their leaders' abilities and have the least confidence in their first and mid level leaders. Seventy-eight percent of the organizations reported difficulty finding qualified leader candidates and $46 \%$ of the organizations do not have a systematic process for identifying and developing good leaders. Companies in the study indicated they would increase funding for leadership development within their organization, because leadership has an effect on the productivity of the company. "Employees with strong leaders are significantly more productive than associates with weak leaders. In an organization with 10,000 employees, this can equate to more than \$28 million in productivity dollars” (Benthal \& Wellins, 2003, p. 4). Benthal and Wellins (2003) indicated that companies will be engaging in a "war for talent" to hire and retain employees that have great leadership capabilities. A potential cure for this problem is to develop an individual's leadership ability at an earlier age.

Leadership development is an important aspect of adolescent development. Leadership skills are essential for young people to feel satisfaction and contribute to society (Scheer, 1997). The development of leadership skills not only helps an individual at a young age, but also serves as a foundation for his/her success and satisfaction in the future. Participation in organizations can lay a leadership foundation among youth that 
they carry with them through life. McKinley, Birkenholz, and Stewart (1993)

investigated participation in organizations and activities that was related to the perceived leadership abilities of students enrolled in the College of Agriculture at the University of Missouri-Columbia. They found "significant relationships between these four factors-interpersonal relations, administration, self management, and communication--and participation in athletics, National Honor Society, FFA, student council, language club, departmental clubs, social fraternity or sorority, intramurals, church groups, 4-H, and livestock association” (p. 81).

The National FFA Organization, a youth organization for students enrolled in agricultural education courses, was founded in 1928 and today has a membership of over 490,000 (National FFA Organization, n.d., A). FFA leadership activities make up onethird of the total high school agricultural education program. The total program consists of classroom instruction, supervised agricultural experience programs (SAEs), and FFA (National FFA, n.d., B). Instruction provided in both the classroom and laboratories covers a wide range of topics, from production agriculture to forestry and from horticulture to soil science. SAEs offer students a way to apply knowledge gained from classroom and laboratory instruction to an out of school experience, based on the student's interests and career aspirations. A students' SAE offers a chance to earn money and earn awards and honors through FFA. FFA is the leadership and recognition component of the total high school agriculture science program. Because of the integral relation between the three components leadership development can also be taught within the classroom. 
Gartin (1991), in his article “Time to Teach Leadership,” stated that students of agricultural education have traditionally gained leadership skills through participation in contests, conventions, hands-on training and through school and community service activities. According to Gartin (1991) the need for high quality leadership is more critical now than ever before and the focus on leadership development should change from traditional means mentioned above, to educating students about leadership qualities and styles. Once a student recognizes his/her leadership style and the strengths and weaknesses associated with it they can better understand the styles of the people they work with and can grow into better leaders.

Outside of the classroom many opportunities are available for FFA members to gain instruction on leadership. The National FFA Organization offers leadership development workshops to members at the National FFA Convention and at the Washington Leadership Conference. The National FFA Organization tailors leadership conferences for various age groups. For example, Experiencing Discovery, Growth \& Excellence Conference (EDGE) is designed for students in grades 7-8, Made for Excellence Conference (MFE) is aimed at grades 9-10, and Advanced Leadership Development (ALD) targets grades 11-12 (National FFA Organization, 2005).

At the state level leadership development activities are also prevalent. Numerous state FFA associations host leadership conferences throughout the year. West Virginia hosts a three day Winter Leadership Conference in January (West Virginia FFA Association, n.d.). Pennsylvania FFA offers leadership training to members through Agricultural Cooperation Establishes Success (ACES), State Legislative Leadership Conference (SLLC), and State Officer Candidacy School (SOCC) (Pennsylvania FFA 
Association, n.d.). Maryland FFA hosts a state leadership training conference in the fall (Maryland FFA Association, n.d.). Tennessee FFA holds a weeklong leadership conference each summer at Camp Clements (Tennessee FFA Association, n.d.). A state leadership conference for Texas FFA members is held in June (Texas FFA Association, n.d.). Florida FFA holds three leadership conferences throughout the year; State Leadership School (SLS), Chapter Presidents’ Conference (CPC), and Area Leadership School (ALS) (Florida FFA Association, n.d.). The Michigan FFA Association holds a state leadership conference for both chapter and regional FFA officers (Michigan FFA Association, n.d.).

Of the state and national leadership activities offered, the National FFA Convention draws the largest number of members, 51,338 , a mere $10 \%$ of the total membership (National FFA Organization, n.d., A). Washington leadership conference has the next largest attendance of 2,300 (0.4\%) members attending throughout the seven weeks the conference is offered (National FFA Organization, n.d., C). State associations reach even fewer members.

\section{Statement of the Problem}

In order for more FFA members and agricultural education students to receive instruction and training in leadership skills areas it must be done at the chapter level. More than 11,000 teachers are delivering instruction in agricultural science classrooms across the country (National FFA Organization, n.d., B). These classrooms and local FFA chapters are where leadership needs to be taught and applied. No research has been conducted on the type of leadership skills taught, the importance of such skills, and the frequency of instruction at the chapter level. 


\section{Purpose of the Study}

The purpose of this study was to determine the importance of different leadership skills taught to agriculture students and FFA members at the chapter level, where students and members receive leadership training, the frequency of training, and identify the instructors that provide leadership training.

Objectives of the Study

The objectives of this study were to determine types, frequencies, importance, and location of leadership training or education provided at the chapter FFA level. As a means of developing this study answers to the following questions were sought:

1. In what contexts do agricultural science instructors provide leadership training?

2. What leadership skills do agricultural science instructors consider most important for agriculture students to receive training or instruction?

3. How often agriculture students are provided training for specific skills?

4. Who assists agricultural science instructors in providing leadership training at the chapter level?

\section{Limitations to the Study}

The findings of this research study will be limited to agricultural science teachers who serve as FFA advisors of chapters that were recognized in the National Chapter Award Program at the $78^{\text {th }}$ National FFA Convention. These instructors and agricultural science programs are not representative of all teachers and programs. 


\section{CHAPTER II}

Review of Literature

\section{Historical Overview of Federal Vocational Education Legislation}

Federal funding for vocational education was initiated with the passing of the Smith-Hughes Act in 1917. This was

An act to provide for the promotion of vocational education; to provide for cooperation with the States in the promotion of such education in agriculture and the trades and industries; to provide for cooperation with the States in the preparation of teachers of vocational subjects; and to appropriate money and regulate its expenditures (National Vocational Education [Smith-Hughes] Act).

In 1963, the Vocational Education Act (P.L. 88-210) was signed into law. In addition to increasing federal support for vocational education in schools, the act also provided funding for vocational work-study programs and research, training, and demonstration programs related to vocational education (Skinner \& Apling, 2005).

Five years later, the Vocational Education Amendments of 1968 (P.L. 90576) modified the existing vocational education programs. The amendments also established a National Advisory Council on Vocational Education and provided funding for collecting and disseminating information about programs administered by the Commissioner of Education (Skinner \& Apling, 2005).

In 1984, The Vocational Education Act was renamed the Carl D. Perkins Vocational Education Act (Perkins I, P.L. 98-524). While continuing federal 
support for vocational education, it established programs emphasizing the acquisition of job skills through vocational and technical education. Historical View of Components of High School Agricultural Science Programs

After vocational education was initiated with the Smith-Hughes Act of 1917 many individuals authored handbooks for teaching vocational agriculture. Within their pages they discussed the components that should comprise a high school agriculture program. Cook (1947) identified five components; classroom instruction, supervised farming programs, farm mechanics, Future Farmers of America (FFA), and farmer classes. Cook identified classroom instruction to involve areas of production agriculture. "Supervised farming consists of all the farming activities of educational value conducted by students enrolled in vocational agriculture and for which systematic instruction and supervision is provided by the teacher" (Cook, p. 277). The author stressed the importance of supervised farming programs because they provided students opportunities to learn through experience in real-life activities. These programs gave students the opportunity to apply knowledge and skills obtained through systematic instruction from the classroom to their home farming situation. The farm mechanics component refers to shop activities taught in an agriculture program. Common areas of instruction were farm shop work, farm power and machinery, farm buildings and conveniences, soil and water management, and rural electrification. Cook wrote the Future Farmers of America is an integral part of the vocational agriculture program. "The foundation upon which the Future Farmers of America organization is built includes leadership and character development, sportsmanship, cooperation, service, thrift, scholarship, improved agriculture, organized recreation, citizenship, and patriotism” (p. 503). The final 
component Cook described was farmer classes for both young and adult farmers. These classes provided instruction on an agricultural need to members of the community. Hamlin provided another view on the components of high school agriculture programs in 1949. "High-school vocational agriculture has been compounded of three parts: classroom teaching, supervised practice, and the Future Farmers of America (FFA)" (p.224). Classroom instruction was the study of production agriculture and was no more than a classroom subject in schools. Supervised practice developed after the passage of the Smith-Hughes Act of 1917. The thought was to provide six months of instruction and six months for of supervised or directed practice on the home farm to provide a "learning by doing" situation. The FFA is an intra-curricular component of the high school agriculture program and provides opportunities to educate students on cooperation and leadership.

Phipps and Cook co-authored A Handbook on Teaching Vocational Agriculture in 1952. The two described high school agriculture programs contained five major phases:

1) Classroom activities,

2) Supervised farming programs,

3) Farm mechanics activities,

4) Training in food preservation in school-community canneries,

5) School sponsored organizations, such as Future Farmers of America (FFA). Classroom activities provide opportunities for students to study and discuss problems related to farming programs and farm living. Ares of instruction included animal husbandry, dairy, poultry, field crops, horticulture, soils, marketing, rural economics, farm management, accounting, and farm mechanics. Supervised farming programs 
provided students the opportunity to apply knowledge and skills learned at school to their own home farming situations. These programs enable a student to establish their own farming operation and are under the supervision and guidance of the vocational agriculture instructor. The component of farm mechanics activities covers a broad field training areas that include: farm shop work, farm power and machinery, farm buildings and conveniences, rural electrification, and soil and water management. Phipps and Cook stated food preservation in school-community canneries as an important phase of the program. This phase was recognized as a contributing factor to a more satisfactory home living and has developed great school-community relationships.

Phipps and Osborne describe the instructional components of vocational agriculture programs in the Handbook on Agricultural Education in Public Schools, $5^{\text {th }}$ edition, (1988) to include the following components:

1) Classroom instruction,

2) Supervised occupational experience programs,

3) Laboratory instruction,

4) Vocational student organization.

In the classroom students study and discuss problems pertaining to specific areas of agriculture. As a result, students gain the necessary knowledge and information that will allow them to arrive at potential solutions to agricultural problems. Supervised occupational experience (SOE) programs serve a vital role in a agriculture program. SOEs allow students to apply knowledge and skills learned in the classroom to real life situations. The types of SOE programs available for students include productive enterprises, farm or agri-business placement, directed laboratory experiences, exploratory 
experiences, improvement projects, and supplementary skills. Laboratory instruction provides an educational setting for students to develop psychomotor skills and apply principles gained from classroom instruction. Use of laboratory instruction is essential for students to develop skills from classroom instruction. Phipps and Osborne describe the FFA as the vocational student organization in agriculture. It is a national organization of, by, and for the students studying vocational agriculture in public secondary schools. The FFA is an intra-curricular part of an agriculture program designed to develop agricultural leadership, character, thrift, scholarship, cooperation, citizenship, and patriotism.

Today the National FFA Organization recognizes that the total program consists of Instruction, Supervised Agricultural Experience programs (SAEs), and FFA (National FFA, n.d.). Instruction provided in both the classroom and laboratories covers a wide range of topics, from production agriculture to forestry and from horticulture to soil science. SAEs offer students a way to apply knowledge gained from classroom and laboratory instruction to an out of school experience, based on students' interests and career aspirations. Their SAE offers a chance to earn money and earn awards and honors through FFA. FFA is the leadership and recognition component of the total high school agriculture science program. Because of the integral relation between the three components leadership development can also be taught within the classroom.

\section{Leadership Defined}

The word leadership carries with it many thoughts, ideas, definitions, and characteristics. Stodgill (1974) concluded that, "there are almost as many definitions of leadership development as there are persons who have attempted to define the concept" 
(p. 259). Webster (1996) provides a definition of leadership as having the "capacity to lead”. Maxwell (1999) noted that leadership stems from various personal characteristics; they include character, charisma, commitment, communication, competence, courage, discernment, focus, generosity, initiative, listening, passion, positive attitude, problem solving, relationships, responsibility, security, self-discipline, servanthood, teachability, and vision. Vandeever and Menefee (2006, p. 90) wrote, "Leadership is the ability to influence other people toward certain goals and objectives”.

\section{Leadership Abilities Increase From Involvement in FFA}

Townsend and Carter (1982) found that leadership traits of youth could be enhanced by participation in FFA activities. Their research suggests that members who were involved in more activities at the local level and with activities that had different levels of participation had higher perceptions about their leadership abilities. Townsend and Carter concluded that local FFA chapters should continue to stress individual participation at the local level in order to fulfill their aims and objectives.

Townsend and Carter (1983) studied the relationship of participation in FFA activities and leadership, citizenship, and cooperation. They found that youth organization activity participation had a positive correlation with the leadership of $12^{\text {th }}$ grade students in Iowa. The participants in their study based their response from involvement on 18 different FFA activities.

A 1984 study by Ricketts and Newcomb investigated the relationship between leadership and personal development of vocational, as compared to non-vocational, agricultural students. Their research found that leadership abilities of FFA members were directly related to the activity level of the individual within the chapter. Students 
who were more active tended to have higher levels of leadership and personal development ability. They also found that vocational agriculture students/FFA members possessed significantly higher leadership and personal development abilities than nonvocational students.

Dormody and Seevers (1994) cited FFA members as saying participation in judging contests, public speaking, chapter meetings, holding office, and parliamentary procedure were activities that made the greatest contribution to their leadership life skills development. This statement was a result of a tri-state study of FFA members from Arizona, Colorado, and New Mexico.

Wingenbach and Kahler (1997) found positive relationships between youth leadership and life skill development scale scores and participation in FFA leadership activities. The authors pointed out that "... students at the secondary level could increase their leadership skills in communications, decision making, getting along with others, learning management of self, understanding self, and working with groups by participating in a combination of youth leadership organizations in school and/or community activities" (p. 19). Their research was on self-perceived youth leadership and life skills of Iowa FFA members from the 1994-1995 Iowa FFA membership roster.

Rutherford, Townsend, Briers, Cummins, and Conrad (2002) studied the association between Washington Leadership Conference participants and their selfperception of their leadership skills. From their research findings they recommend that FFA members be encouraged to hold at least one chapter officer position because of the greater access to leadership training. They also recommend that quantity and quality of participation in FFA activities is more important than the length of membership because 
the opportunity to experience and practice skills through FFA activities is a vital factor in developing leadership skills.

Ricketts and Rudd (2004) found that the most influential construct for development of leadership abilities of former Florida state FFA officers to be the agricultural education program. The second most influential factor was FFA involvement. This construct included items that included FFA knowledge, participation in career development events, and simply being an active member. The most important FFA activity was leadership conferences the respondents attended as FFA members. 


\section{CHAPTER III}

\section{Methodology}

Purpose of the Study

The purpose of this study was to determine the importance of different leadership skills taught to agriculture students and FFA members at the chapter level, where students and members receive leadership training, the frequency of training, and the instructors that provide leadership training.

Objectives of the Study

The objective of this study was to determine types, frequencies, importance, and location of leadership training or education provided at the chapter FFA level. In order to reach this objective answers to the following research questions were sought:

1. In what contexts do agricultural science instructors provide leadership training?

2. What leadership skills do agricultural science instructors consider most important for agriculture students to receive training or instruction?

3. How often are agriculture students provided training for specific leadership skills?

4. Who assists agricultural science instructors in providing leadership training at the chapter level?

\section{Population}

The target population for this study was agricultural science teachers who serve as FFA advisors of chapters that were recognized in the National Chapter Award Program at the $78^{\text {th }}$ National FFA Convention $(N=585)$. 
Based on the Krejcie and Morgan (1970) table for determining sample size for research activities a sample population of 230 participants was randomly selected using the Statistical Package for the Social Sciences (SPSS). The random sample was reviewed to determine if all states involved in the National Chapter Award Program were represented. Three additional participants were selectively added to ensure that all states had one participant in the study. The total sample population for the study was $N=233$.

The list of National Chapter Award recipients was located at the National FFA website. After the sample population was randomly selected addresses for the chapters were obtained from the website, www.high-schools.com. The addresses were rechecked to avoid frame error. The completed list was scanned for duplicates to control selection error.

Non-response error was controlled by comparing early and late respondents because research has shown "nonrespondents are often similar to late respondents" (Ary, Jacobs, Razavieh, \& Sorensen, 2005, p. 439). Respondents were categorized between early and late groups to compare their responses for any significant relationships.

\section{Research Design}

Descriptive survey research methods were used to collect data from the accessible population. Descriptive research is "research that asks questions about the nature, incidence, or distribution of variables; it involves describing but not manipulating variables” (Ary, Jacobs, Razavieh, \& Sorensen 2005, p. 632). This study was conducted to identify the importance of various leadership skills and training procedures used by chapter FFA advisors. 


\section{Instrumentation}

The researcher developed the survey instrument (see Appendix A) based on the list of 100 topics for workshops during chapter FFA officer training listed in Mpower, a chapter officer training resource guide promoted the National FFA Organization. The instrument allowed participants to identify the location students receive training (classroom, FFA meetings, special training, one on one, or not at all), the importance of the topics (a rating scale with the range of 1 not important to 6 very important), and the frequency topics were covered (1 per year, 2-3 per year, 4-5 per year, 6+ per year). Demographic questions were included to determine the size of the high school, size of agricultural education program, FFA membership, number of agricultural science teachers, and years teaching experience. Other information requested in the survey was who assists the agriculture teacher/FFA advisor in providing leadership training.

\section{Validity}

The revised instrument was presented to members of the researcher's graduate committee to establish its content and face validity. The graduate committee consisted of teacher educators in Agricultural and Environmental Education at a land-grant university in the North Central Region of American Association of Agriculture Educators. The graduate committee concluded the instrument had content and face validity.

\section{Reliability}

Reliability was established using the entire dataset and the Statistical Package for the Social Sciences’ (SPSS) split-half analysis procedures. Split-half analysis was run on the three constructs: location of training, importance of leadership skills, and frequency of instruction. The equal-length Spearman-Brown values for location of training, 
importance of leadership skills, and frequency of instruction were found to be exemplary (Robinson, Shaver, \& Wrightsman, 1991) with values of .99, .55, and .80 respectively.

\section{Data Collection}

Following Dillman's protocol for data collection, the researcher made two attempts at gathering data from the sample population. The researcher mailed a selfadministered questionnaire (see Appendix A), a cover letter (see Appendix B), and selfaddressed return envelope to participants of the study on January 24, 2006. The deadline for the first mailing was February 8, 2006. On February 14, 2006 all non-respondents to the first mailing were sent a follow-up cover letter, (see Appendix C) an additional copy of the questionnaire and a self-addressed return envelope. The deadline for the second mailing was February 28, 2006. A total of 62 completed questionnaires were returned, for a $26 \%$ response rate.

Analysis of Data

Data were analyzed utilizing the Statistical Package for the Social Sciences (SPSS) 11.0 for Windows. Descriptive analyses appropriate for the respective scale of measurement were performed on the data including measures of central tendency (mean, median, or mode) and variability (frequencies or standard deviation). The results were represented as frequencies and percentages in both table and narrative form.

Prior to analyzing the data the list of 100 skills were divided into nine groups through qualitative research techniques. The groups were identified by a general category that skills would fit in. The nine groups are; appearance qualities, creative thinking skills, educational materials, leadership abilities, oral communication skills, 
personal skills, planning and teamwork skills, leadership qualities, and written communication skills.

Use of Findings

The results of this study will be utilized by agricultural science instructors to identify areas of leadership development that can be incorporated into their agricultural science program and FFA chapter. The results will also be used by teacher educators in preparing student teachers. 


\section{CHAPTER IV}

\section{Findings}

\section{Purpose of Study}

The purpose of this study was to determine the importance of different leadership skills taught to agriculture students and FFA members at the chapter level, where students and members receive leadership training, the frequency of training, and the instructors that provide leadership training.

\section{Objectives of the Study}

The objectives of this study were to determine types, frequencies, importance, and location of leadership training or education provided at the chapter FFA level. As a means of developing this study answers to the following questions were sought:

1. In what contexts do agricultural science instructors provide leadership training?

2. What leadership skills do agricultural science instructors consider most important for agriculture students to receive training or instruction?

3. How often agriculture students are provided training for specific skills?

4. Who assists agricultural science instructors in providing leadership training at the chapter level?

\section{Findings}

The sample population $(N=233)$ was agricultural science teachers who serve as FFA advisors of chapters recognized through the National Chapter Award Program at the $78^{\text {th }}$ National FFA Convention. A total of 62 completed surveys were returned, for a $26 \%$ response rate. 
Ary, Jacobs, Razavieh, \& Sorensen (2005) guiding principle to generalize the respondents to the entire population is to determine the degree to which respondents differ from non-respondents by comparing early and late respondents. Sixty-two surveys were returned completed, 28 were early respondents and 34 were late respondents. An independent $t$-test statistical procedure was used to determine if there were significant differences between early and late respondents. Research has shown "nonrespondents are often similar to late respondents” (Ary, Jacobs, Razavieh, \& Sorensen, 2005, p. 439). No significant difference was found between early and late respondents. The findings could be generalized to the entire population of agricultural science teachers who serve as FFA advisors of chapters recognized through the National Chapter Award Program at the $78^{\text {th }}$ National FFA Convention. Because of the low response rate, the researcher elected to limit generalizations to the agricultural science teachers who responded to the survey. Demographic Characteristics of Respondents

Demographic data indicates that high school enrollment ranged from a minimum of 54 students to a high of 3200 students with a mean of 820.59 students $(s d=740.43)$. The average number of students enrolled in the respondent's agricultural science program was 161 students ( $s d=96.35)$ with a minimum of 41 students and a maximum of 500 students. FFA membership of the responding programs ranged from a low of 35members to a high of 460 members, with a mean of 136.66 members $(s d=93.13)$. The agricultural science programs that responded to the questionnaire had a mean of 1.71 teachers ( $s d=$ 0.84). The minimum was one teacher and the largest department had four teachers (see Table 1). 
Table 1

Demographic Characteristics of Respondents

\begin{tabular}{lcccc}
\hline & $M$ & $S D$ & Minimum & Maximum \\
\hline HS Student Enrollment & 820.59 & 750.43 & 54.00 & 3200.00 \\
Ag Program enrollment & 161.00 & 96.35 & 41.00 & 500.00 \\
FFA Membership & 136.66 & 93.13 & 35.00 & 460.00 \\
Number of Teachers & 1.71 & 0.84 & 1.00 & 4.00 \\
\hline
\end{tabular}

\section{Years Teaching Experience}

The number of years teaching experience for all agricultural science teachers within their program were identified by the respondents. Agricultural science teachers from responding programs had taught an average of 13.16 years with a standard deviation of 10.51 years. The minimum years teaching experience was one year with a maximum of 48 years teaching experience (see Table 2).

Table 2

Years Teaching Experience

\begin{tabular}{ccccc}
\hline & $M$ & $S D$ & Minimum & Maximum \\
\hline Years Teaching & 13.16 & 10.51 & 1 & 48 \\
\hline
\end{tabular}

The importance scale used in the research identified mean scores ranging from 5.51-6 as very important, 4.51-5.50 as important, and 3.51-4.50 as somewhat important. All skills in the study received a mean score above 3.51 . 
Importance, Frequency, and Location of Instruction of Appearance Skills

Professional dress. Respondents were asked the frequency they taught professional dress and the importance they place on teaching the topic to their students. Using a scale of 1-6 with 1 being "not important" and 6 "very important" the average rating of the importance of teaching professional dress was $5.10(\mathrm{SD}=.96)$ (see Table 3). Three respondents (5.0\%) taught professional dress once a year. The topic was taught 23 times per year by 24 respondents (40.0\%), 4-5 times per year by 10 respondents (16.7\%), and 6 or more times per year by 23 respondents (38.3\%) (see Table 3).

Table 3

Importance \& Frequency of Appearance Qualities

\begin{tabular}{|c|c|c|c|c|c|c|c|c|c|c|}
\hline & \multirow{2}{*}{\multicolumn{2}{|c|}{ Importance }} & \multicolumn{8}{|c|}{ Frequency } \\
\hline & & & \multicolumn{2}{|c|}{$\begin{array}{l}1 \text { time per } \\
\text { year }\end{array}$} & \multicolumn{2}{|c|}{$\begin{array}{l}\text { 2-3 times } \\
\text { per year }\end{array}$} & \multicolumn{2}{|c|}{$\begin{array}{l}4-5 \text { times } \\
\text { per year }\end{array}$} & \multicolumn{2}{|c|}{$\begin{array}{c}6 \text { or more } \\
\text { times per } \\
\text { year }\end{array}$} \\
\hline & $M$ & $S D$ & $N$ & $\%$ & $N$ & $\%$ & $N$ & $\%$ & $N$ & $\%$ \\
\hline Professional dress & 5.10 & .96 & 3 & 5.0 & 24 & 40.0 & 10 & 16.7 & 23 & 38.3 \\
\hline Personal hygiene and attire & 4.96 & 1.16 & 10 & 18.9 & 20 & 37.7 & 8 & 15.1 & 15 & 28.3 \\
\hline $\begin{array}{l}\text { Utilizing proper travel } \\
\text { etiquette }\end{array}$ & 4.71 & 1.24 & 9 & 16.7 & 24 & 44.4 & 7 & 13.0 & 14 & 25.9 \\
\hline $\begin{array}{l}\text { Using proper dining } \\
\text { etiquette }\end{array}$ & 4.64 & 1.18 & 12 & 21.4 & 24 & 42.9 & 7 & 12.5 & 13 & 23.2 \\
\hline Tying a tie & 3.59 & 1.47 & 24 & 42.1 & 19 & 33.3 & 7 & 12.3 & 7 & 12.3 \\
\hline
\end{tabular}

Importance Scale: 1 - Not Important 6 - Very Important

Respondents were asked where they taught the topic of professional dress. Fortyfive respondents (75\%) taught professional dress in both the classroom and at FFA meetings. Of the remaining respondents 28 (46.7\%) taught the topic at special training, 
24 instructors (40.0\%) taught the topic one-on-one, and two respondents (3.3\%) did not teach the topic (see Table 4).

Table 4

Location Where Appearance Qualities Skills were Taught

\begin{tabular}{|c|c|c|c|c|}
\hline & \multicolumn{2}{|c|}{ Not Taught } & \multicolumn{2}{|c|}{ Taught } \\
\hline & $N$ & $\%$ & $N$ & $\%$ \\
\hline \multicolumn{5}{|l|}{ Tying a tie } \\
\hline Classroom & 37 & 60.7 & 24 & 39.3 \\
\hline FFA Meeting & 48 & 78.7 & 13 & 21.3 \\
\hline Special Training & 56 & 91.8 & 5 & 8.2 \\
\hline One-on-one & 28 & 45.9 & 33 & 54.1 \\
\hline Not at all & 54 & 88.5 & 7 & 11.5 \\
\hline \multicolumn{5}{|l|}{ Professional dress } \\
\hline Classroom & 15 & 25.0 & 45 & 75.0 \\
\hline FFA Meeting & 15 & 25.0 & 45 & 75.0 \\
\hline Special Training & 32 & 53.3 & 28 & 46.7 \\
\hline One-on-one & 36 & 60.0 & 24 & 40.0 \\
\hline Not at all & 58 & 96.7 & 2 & 3.3 \\
\hline \multicolumn{5}{|c|}{ Utilizing proper travel etiquette } \\
\hline Classroom & 40 & 67.8 & 19 & 32.2 \\
\hline FFA Meeting & 35 & 59.3 & 24 & 40.7 \\
\hline Special Training & 28 & 47.5 & 31 & 52.5 \\
\hline One-on-one & 28 & 47.5 & 31 & 52.5 \\
\hline Not at all & 54 & 91.5 & 5 & 8.5 \\
\hline
\end{tabular}


Table 4 (Continued)

Location Where Appearance Qualities Skills were Taught

\begin{tabular}{lcccc}
\hline & \multicolumn{2}{c}{ Not Taught } & \multicolumn{2}{c}{ Taught } \\
\cline { 2 - 4 } & $N$ & $\%$ & $N$ & $\%$ \\
\hline Using proper dining etiquette & & & & \\
Classroom & 43 & 70.5 & 18 & 29.5 \\
FFA Meeting & 37 & 60.7 & 24 & 39.3 \\
Special Training & 26 & 42.6 & 35 & 57.4 \\
One-on-one & 30 & 49.2 & 31 & 50.8 \\
Not at all & 56 & 91.8 & 5 & 8.2 \\
Personal hygiene and attire & & & & \\
Classroom & 17 & 28.8 & 42 & 71.2 \\
FFA Meeting & 36 & 61.0 & 23 & 39.0 \\
Special Training & 51 & 69.5 & 18 & 30.5 \\
One-on-one & 25 & 41.7 & 35 & 58.3 \\
Not at all & 52 & 88.1 & 7 & 11.9 \\
\hline
\end{tabular}

Personal hygiene and attire. Agricultural science teachers were asked the frequency they taught personal hygiene and attire and the importance they place on teaching the topics to their students. Using a scale of 1-6 with 1 being "not important" and 6 "very important" the average rating of the importance of teaching personal hygiene and attire was $4.96(\mathrm{SD}=1.16)$ (see Table 3). Ten respondents $(18.9 \%)$ taught personal hygiene and attire once a year. The topics were taught 2-3 times per year by 20 
respondents (37.7\%), 4-5 times per year by eight respondents (15.1\%), and 6 or more times per year by 15 respondents (28.3\%) (see Table 3).

Agricultural science teachers were asked where they taught personal hygiene and attire. Forty-two respondents (71.2\%) taught personal hygiene and attire in the classroom and 23 respondents (39\%) at FFA meetings. Of the remaining respondents 18 (30.5\%) taught the topics at special training, 35 instructors (58.3\%) taught the topics one-on-one, and seven respondents (11.9\%) did not teach the topics (see Table 4).

Proper travel etiquette. Respondents were asked the frequency they taught proper travel etiquette and the importance they place on teaching the skill to their students. Using a scale of 1-6 with 1 being "not important” and 6 "very important" the average rating of the importance of teaching proper travel etiquette was $4.71(\mathrm{SD}=1.24)$ (see Table 3). Nine respondents (16.7\%) taught proper travel etiquette once a year. The skill was taught 2-3 times per year by 24 respondents (44.4\%), 4-5 times per year by seven respondents (13.0\%), and 6 or more times per year by 14 respondents (25.9\%) (see Table 3).

Agricultural science teachers were asked where they taught the skill of proper travel etiquette. Nineteen respondents (32.2\%) taught proper travel etiquette in the classroom and 24 respondents (40.7\%) at FFA meetings. Of the remaining respondents 31 (52.5\%) taught the skill at both special training and one-on-one instruction, and five teachers (8.2\%) did not teach the skill (see Table 4).

Proper dining etiquette. Agricultural science teachers were asked the frequency they taught proper dining etiquette and the importance they place on teaching the skill to their students. Using a scale of 1-6 with 1 being "not important” and 6 "very important” 
the average rating of the importance of teaching proper dining etiquette was 4.64 (SD = 1.18) (see Table 3). Twelve respondents (21.4\%) taught proper dining etiquette once a year. The skill was taught 2-3 times per year by 24 respondents (42.9\%), 4-5 times per year by seven respondents (12.5\%), and 6 or more times per year by 13 respondents (23.2\%) (see Table 3).

Respondents were asked where they taught the skill of proper dining etiquette. Eighteen respondents (29.5\%) taught proper dining etiquette in the classroom and 24 teachers (39.3\%) identified they taught proper dining etiquette at FFA meetings. Of the remaining respondents 35 (57.4\%) taught the skill at special training, 31 instructors (50.8\%) taught the skill one-on-one, and five respondents (8.2\%) did not teach the skill (see Table 4).

Tying a tie. FFA advisors were asked the frequency they taught the skill tying a tie and the importance they place on teaching the skill to their students. Using a scale of 1-6 with 1 being "not important” and 6 "very important” the average rating of the importance of teaching tying a tie was $3.59(\mathrm{SD}=1.48)$ (see Table 3). Twenty-four respondents (42.1\%) taught tying a tie once a year. The skill was taught 2-3 times per year by 19 respondents (33.3\%), 4-5 times per year and 6 or more times per year by seven respondents (12.3\%) (see Table 3).

Respondents were asked where they taught the skill of tying a tie. Twenty-four teachers (39.3\%) taught tying a tie in the classroom and 13 teachers (21.3\%) identified they taught tying a tie at FFA meetings. Of the remaining teachers, five (8.2\%) taught the skill at special training, 33 instructors (54.1\%) taught the skill one-on-one, and seven respondents (11.5\%) did not teach the skill (see Table 4). 
Importance, Frequency, and Location of Instruction of Creative Thinking Skills

Creating executive meetings that your fellow officers will not want to miss.

Agricultural science teachers were asked the frequency they taught creating executive meetings that your fellow officers will not want to miss and the importance they place on teaching the skill to their students. Using a scale of 1-6 with 1 being "not important" and 6 "very important" the average rating of the importance of teaching creating executive meetings that your fellow officers will not want to miss was $4.59(\mathrm{SD}=1.18)$ (see Table 5). Nine respondents (17\%) taught creating executive meetings that your fellow officers will not want to miss once a year. The skills were taught 2-3 times per year by 20 respondents (37.7\%), 4-5 times per year by seven respondents (13.2\%), and 6 or more times per year by 17 respondents (32.1\%) (see Table 5).

Respondents were asked where they taught the skill of creating executive meetings that your fellow officers will not want to miss. Ten respondents (16.4\%) taught creating executive meetings that your fellow officers will not want to miss in the classroom and 38 teachers (62.3\%) identified they taught creating executive meetings that your fellow officers will not want to miss at FFA meetings. Of the remaining respondents 29 (47.5\%) taught the skill at special training, 18 instructors (29.5\%) taught the skill one-on-one, and eight respondents (13.1\%) did not teach the skill (see Table 6). 
Table 5

Importance \& Frequency of Creative Thinking Skills

\begin{tabular}{|c|c|c|c|c|c|c|c|c|c|c|}
\hline & \multirow{2}{*}{\multicolumn{2}{|c|}{ Importance }} & \multicolumn{8}{|c|}{ Frequency } \\
\hline & & & \multicolumn{2}{|c|}{$\begin{array}{l}1 \text { time per } \\
\text { year }\end{array}$} & \multicolumn{2}{|c|}{$\begin{array}{l}\text { 2-3 times } \\
\text { per year }\end{array}$} & \multicolumn{2}{|c|}{$\begin{array}{l}4-5 \text { times } \\
\text { per year }\end{array}$} & \multicolumn{2}{|c|}{$\begin{array}{l}6 \text { or more } \\
\text { times per } \\
\text { year }\end{array}$} \\
\hline & $M$ & $S D$ & $\mathrm{~N}$ & $\%$ & $N$ & $\%$ & $N$ & $\%$ & $N$ & $\%$ \\
\hline $\begin{array}{l}\text { Creating executive } \\
\text { meetings that your } \\
\text { fellow officers will } \\
\text { not want to miss }\end{array}$ & 4.59 & 1.18 & 9 & 17.0 & 20 & 37.7 & 7 & 13.2 & 17 & 32.1 \\
\hline Banquet ideas that work & 4.46 & 1.21 & 20 & 35.7 & 19 & 33.9 & 9 & 16.1 & 8 & 14.3 \\
\hline $\begin{array}{l}\text { Great meeting } \\
\text { activities-mixers, } \\
\text { icebreakers, } \\
\text { energizers }\end{array}$ & 4.43 & 1.22 & 8 & 15.7 & 20 & 39.2 & 12 & 23.5 & 11 & 21.6 \\
\hline $\begin{array}{c}\text { Enhancing your } \\
\text { creativity }\end{array}$ & 4.36 & 1.22 & 11 & 21.2 & 24 & 46.2 & 9 & 17.3 & 8 & 15.4 \\
\hline $\begin{array}{l}\text { Generating great ideas } \\
\text { for skits, meeting } \\
\text { activities, and } \\
\text { presentations }\end{array}$ & 4.25 & 1.28 & 5 & 8.8 & 17 & 29.8 & 18 & 31.6 & 17 & 29.8 \\
\hline $\begin{array}{l}\text { Creating super slide } \\
\text { shows }\end{array}$ & 3.76 & 1.56 & 17 & 38.6 & 14 & 31.8 & 4 & 9.1 & 9 & 20.5 \\
\hline
\end{tabular}

Importance Scale: 1 - Not Important 6 - Very Important 
Table 6

Location Creative Thinking Skills are Taught

\begin{tabular}{ccccc}
\hline Not Taught & \multicolumn{3}{c}{ Taught } \\
\cline { 2 - 5 } & $N$ & $\%$ & $N$ & $\%$ \\
\hline
\end{tabular}

Generating great ideas for skits,

meeting activities, and presentations

Classroom

FFA Meeting

Special Training

One-on-one

Not at all

Creating executive meetings that your fellow officers will not want to miss

Classroom

FFA Meeting

Special Training

One-on-one

Not at all

Creating super slide shows

Classroom

FFA Meeting

Special Training

One-on-one

Not at all shows
29

28

27

39

57

51

23

32

43

53

32

42

41

41

41
47.5

32

45.9

33

44.3

63.9

93.4
83.6

10

37.7

38

52.5

70.5

86.9

8

29

18

29.5

13.1

16.4

62.3

47.5

45.8

28.8

30.5

$69.5 \quad 18$

69.5

18

30.5

69.5

18

30.5 
Table 6 (Continued)

Location Creative Thinking Skills are Taught

\begin{tabular}{|c|c|c|c|c|}
\hline & \multicolumn{2}{|c|}{ Not Taught } & \multicolumn{2}{|c|}{ Taught } \\
\hline & $N$ & $\%$ & $N$ & $\%$ \\
\hline \multicolumn{5}{|c|}{$\begin{array}{l}\text { Great meeting activities-mixers, } \\
\text { icebreakers, energizers }\end{array}$} \\
\hline Classroom & 30 & 50.0 & 30 & 50.0 \\
\hline FFA Meeting & 23 & 38.3 & 37 & 61.7 \\
\hline Special Training & 24 & 40.0 & 36 & 60.0 \\
\hline One-on-one & 38 & 63.3 & 22 & 36.7 \\
\hline Not at all & 52 & 86.7 & 8 & 13.3 \\
\hline \multicolumn{5}{|c|}{ Enhancing your creativity } \\
\hline Classroom & 23 & 39.7 & 35 & 60.3 \\
\hline FFA Meeting & 39 & 67.2 & 19 & 32.8 \\
\hline Special Training & 37 & 63.8 & 21 & 36.2 \\
\hline One-on-one & 38 & 65.5 & 20 & 34.5 \\
\hline Not at all & 46 & 79.3 & 12 & 20.7 \\
\hline \multicolumn{5}{|c|}{ Banquet ideas that work } \\
\hline Classroom & 40 & 66.7 & 20 & 33.3 \\
\hline FFA Meeting & 21 & 35.0 & 39 & 65.0 \\
\hline Special Training & 29 & 48.3 & 31 & 51.7 \\
\hline One-on-one & 31 & 50.8 & 30 & 49.2 \\
\hline Not at all & 57 & 95.0 & 3 & 5.0 \\
\hline
\end{tabular}


Teaching banquet ideas that work. FFA advisors were asked the frequency they taught teaching banquet ideas that work and the importance they place on teaching the topic to their students. Using a scale of 1-6 with 1 being "not important” and 6 "very important" the average rating of the importance of teaching banquet ideas that work was $4.46(\mathrm{SD}=1.21)$ (see Table 5). Twenty respondents $(35.7 \%)$ taught banquet ideas that work once a year. The topic was taught 2-3 times per year by 19 respondents (33.9\%), 45 times per year by nine (16.1\%), and 6 or more times per year by eight advisors (14.3\%) (see Table 5).

Agricultural science teachers were asked where they taught the topic of banquet ideas that work. Twenty teachers (33.3\%) taught banquet ideas that work in the classroom and 39 teachers (65\%) identified they taught banquet ideas that work at FFA meetings. Of the remaining teachers 31 (51.7\%) taught the topic at special training and 30 respondents (49.2\%) taught the topic one-on-one, three of the respondents (5\%) did not teach the topic (see Table 6).

Great meeting activities-mixers, icebreakers, and energizers. Agricultural science teachers were asked the frequency they taught great meeting activities-mixers, icebreakers, and energizers and the importance they place on teaching the topics to their students. Using a scale of 1-6 with 1 being "not important" and 6 "very important" the average rating of the importance of teaching great meeting activities-mixers, icebreakers, and energizers was $4.43(\mathrm{SD}=1.22)$ (see Table 5). Eight respondents $(15.7 \%)$ taught great meeting activities-mixers, icebreakers, energizers once a year. The topics were taught 2-3 times per year by 20 respondents (39.2\%), 4-5 times per year by 12 
respondents (23.5\%), and 6 or more times per year by 11 respondents (21.6\%) (see Table 5).

Respondents were asked where they taught the topics of great meeting activitiesmixers, icebreakers, and energizers. Thirty respondents (50\%) taught great meeting activities-mixers, icebreakers, energizers in the classroom and 37 teachers (61.7\%) identified they taught great meeting activities-mixers, icebreakers, energizers at FFA meetings. Of the remaining respondents 36 (60\%) taught the topics at special training, 22 instructors (36.7\%) taught the topics one-on-one, and eight respondents (13.3\%) did not teach the topics (see Table 6).

Enhancing your creativity. FFA advisors were asked the frequency they taught enhancing your creativity and the importance they place on teaching the topic to their students. Using a scale of 1-6 with 1 being "not important” and 6 "very important” the average rating of the importance of teaching enhancing your creativity was 4.36 (SD = 1.22) (see Table 5). Eleven respondents (21.2\%) taught enhancing your creativity once a year. The topic was taught 2-3 times per year by 24 respondents (46.2\%), 4-5 times per year by nine (17.3\%), and 6 or more times per year by eight advisors (15.4\%) (see Table 5).

Respondents were asked where they taught the topic of enhancing your creativity. Thirty-five respondents (60.3\%) taught enhancing your creativity in the classroom and 19 teachers (32.8\%) identified they taught enhancing your creativity at FFA meetings. Of the remaining respondents, 21 (36.2\%) taught the topic at special training, 20 instructors (34.5\%) taught the topic one-on-one, and 12 respondents (20.7\%) did not teach the topic (see Table 6). 
Generating great ideas for skits, meeting activities, and presentations.

Agricultural science teachers were asked the frequency they taught generating great ideas for skits, meeting activities, and presentations and the importance they place on teaching the topics to their students. Using a scale of 1-6 with 1 being "not important" and 6 "very important” the average rating of the importance of teaching generating great ideas for skits, meeting activities, and presentations was $4.25(\mathrm{SD}=1.28)$ (see Table 5). Five respondents (8.8\%) taught generating great ideas for skits, meeting activities, and presentations once a year. The topics were taught 2-3 times per year by 17 respondents (29.8\%), 4-5 times per year by 18 respondents (31.6\%), and 6 or more times per year by 17 respondents (29.8\%) (see Table 5).

Respondents were asked where they taught the topics of generating great ideas for skits, meeting activities, and presentations. Thirty-two respondents (52.5\%) taught generating great ideas for skits, meeting activities, and presentations in the classroom and 33 teachers (54.1 \%) identified they taught generating great ideas for skits, meeting activities, and presentations at FFA meetings. Of the remaining respondents 34 (55.7\%) taught the topics at special training, 22 instructors (36.1\%) taught the topics one-on-one, and four respondents (6.6\%) did not teach the topics (see Table 6).

Creating super slide shows. FFA advisors were asked the frequency they taught creating super slide shows and the importance they place on teaching the skill to their students. Using a scale of 1-6 with 1 being "not important" and 6 "very important" the average rating of the importance of teaching creating super slide shows was 3.76 (SD = 1.56) (see Table 5). Seventeen respondents (38.6\%) taught creating super slide shows once a year. The skill was taught 2-3 times per year by 14 respondents (31.8\%), 4-5 
times per year by four (9.1\%), and 6 or more times per year by nine advisors (20.5\%) (see Table 5).

Agricultural science teachers were asked where they taught the skill of creating super slide shows. Twenty-seven teachers (45.8\%) taught creating super slide shows in the classroom and 17 teachers (28.8\%) identified they taught creating super slide shows at FFA meetings. Of the remaining teachers 18 (30.5\%) identified they taught the skill at special training, taught the skill one-on-one, or did not teach the skill (see Table 6). Importance, Frequency, and Location of Instruction of Educational Materials

Opportunities in the FFA. FFA advisors were asked the frequency they taught opportunities in the FFA and the importance they place on teaching the topic to their students. Using a scale of 1-6 with 1 being “not important” and 6 "very important” the average rating of the importance of teaching opportunities in the FFA was 5.59 (SD = .70) (see Table 7). Two respondents (3.2\%) taught opportunities in the FFA once a year. The topic was taught 2-3 times per year by nine respondents (14.5\%), 4-5 times per year by eight (12.9\%), and 6 or more times per year by 43 advisors (69.4\%) (see Table 7). 
Table 7

Importance \& Frequency of Educational Materials Skills

\begin{tabular}{|c|c|c|c|c|c|c|c|c|c|c|}
\hline & \multicolumn{4}{|c|}{ Importance } & \multicolumn{4}{|c|}{ Frequency } & & \\
\hline & & & \multicolumn{2}{|c|}{$\begin{array}{l}1 \text { time per } \\
\text { year }\end{array}$} & \multicolumn{2}{|c|}{$\begin{array}{l}2-3 \text { times } \\
\text { per year }\end{array}$} & \multicolumn{2}{|c|}{$\begin{array}{l}\text { 4-5 times } \\
\text { per year }\end{array}$} & \multicolumn{2}{|c|}{$\begin{array}{c}6 \text { or more } \\
\text { times per } \\
\text { year }\end{array}$} \\
\hline & $M$ & $S D$ & $N$ & $\%$ & $N$ & $\%$ & $N$ & $\%$ & $N$ & $\%$ \\
\hline $\begin{array}{l}\text { Opportunities in the } \\
\text { FFA }\end{array}$ & 5.59 & .70 & 2 & 3.2 & 9 & 14.5 & 8 & 12.9 & 43 & 69.4 \\
\hline Ag issues & 4.86 & 1.06 & 5 & 8.8 & 23 & 40.4 & 10 & 17.5 & 19 & 33.3 \\
\hline Organizational structure & 4.67 & 1.01 & 10 & 17.9 & 20 & 35.7 & 12 & 21.4 & 14 & 25.0 \\
\hline Ag Ed Issues & 4.54 & 1.09 & 5 & 9.6 & 24 & 46.2 & 12 & 23.1 & 11 & 21.2 \\
\hline Leadership levels & 4.46 & 1.24 & 11 & 21.6 & 19 & 37.3 & 10 & 19.6 & 11 & 21.6 \\
\hline Leadership styles & 4.46 & 1.13 & 8 & 16.0 & 23 & 46.0 & 11 & 22.0 & 8 & 16.0 \\
\hline Learning styles & 4.31 & 1.15 & 11 & 21.2 & 22 & 42.3 & 12 & 23.1 & 7 & 13.5 \\
\hline
\end{tabular}

Importance Scale: 1 - Not Important 6 - Very Important

Respondents were asked where they taught the topic of opportunities in the FFA. Fifty-eight respondents (93.5\%) taught opportunities in the FFA in the classroom and 54 teachers (87.1\%) identified they taught opportunities in the FFA at FFA meetings. Of the remaining respondents 40 (64.5\%) taught the topic at special training, 36 instructors (58.1\%) taught the topic one-on-one, and one respondent (1.6\%) did not teach the topic (see Table 8). 
Table 8

Location Educational Materials Skills are Taught

\begin{tabular}{|c|c|c|c|c|}
\hline & \multicolumn{2}{|c|}{ Not Taught } & \multicolumn{2}{|c|}{ Taught } \\
\hline & $N$ & $\%$ & $N$ & $\%$ \\
\hline \multicolumn{5}{|c|}{ Opportunities in the FFA } \\
\hline Classroom & 4 & 6.5 & 58 & 93.5 \\
\hline FFA Meeting & 8 & 12.9 & 54 & 87.1 \\
\hline Special Training & 22 & 35.5 & 40 & 64.5 \\
\hline One-on-one & 26 & 41.9 & 36 & 58.1 \\
\hline Not at all & 61 & 98.4 & 1 & 1.6 \\
\hline \multicolumn{5}{|c|}{ Organizational structure } \\
\hline Classroom & 10 & 16.1 & 52 & 83.9 \\
\hline FFA Meeting & 27 & 43.5 & 35 & 56.5 \\
\hline Special Training & 38 & 61.3 & 24 & 38.7 \\
\hline One-on-one & 37 & 59.7 & 25 & 40.3 \\
\hline Not at all & 56 & 90.3 & 6 & 9.7 \\
\hline \multicolumn{5}{|l|}{ Leadership levels } \\
\hline Classroom & 20 & 32.8 & 41 & 67.2 \\
\hline FFA Meeting & 29 & 47.5 & 32 & 52.5 \\
\hline Special Training & 36 & 59.0 & 25 & 41.0 \\
\hline One-on-one & 39 & 63.9 & 22 & 36.1 \\
\hline Not at all & 51 & 83.6 & 10 & 16.4 \\
\hline \multicolumn{5}{|l|}{ Leadership styles } \\
\hline Classroom & 8 & 15.1 & 45 & 84.9 \\
\hline FFA Meeting & 29 & 54.7 & 24 & 45.3 \\
\hline Special Training & 24 & 45.3 & 29 & 54.7 \\
\hline One-on-one & 35 & 66.0 & 18 & 34.0 \\
\hline Not at all & 51 & 96.2 & 2 & 3.8 \\
\hline
\end{tabular}


Table 8 (Continued)

Location Educational Materials Skills are Taught

\begin{tabular}{|c|c|c|c|c|}
\hline & \multicolumn{2}{|c|}{ Not Taught } & \multicolumn{2}{|c|}{ Taught } \\
\hline & $N$ & $\%$ & $N$ & $\%$ \\
\hline \multicolumn{5}{|l|}{ Learning styles } \\
\hline Classroom & 12 & 20.3 & 47 & 79.7 \\
\hline FFA Meeting & 45 & 76.3 & 14 & 23.7 \\
\hline Special Training & 39 & 66.1 & 20 & 33.9 \\
\hline One-on-one & 44 & 74.6 & 15 & 25.4 \\
\hline Not at all & 51 & 86.4 & 8 & 13.6 \\
\hline \multicolumn{5}{|l|}{ Ag issues } \\
\hline Classroom & 5 & 8.2 & 56 & 91.8 \\
\hline FFA Meeting & 35 & 57.4 & 26 & 42.6 \\
\hline Special Training & 36 & 59.0 & 25 & 41.0 \\
\hline One-on-one & 37 & 60.7 & 24 & 39.3 \\
\hline Not at all & 59 & 96.7 & 2 & 3.3 \\
\hline \multicolumn{5}{|l|}{ Ag Ed Issues } \\
\hline Classroom & 16 & 26.2 & 45 & 73.8 \\
\hline FFA Meeting & 40 & 65.6 & 21 & 34.4 \\
\hline Special Training & 46 & 75.4 & 15 & 24.6 \\
\hline One-on-one & 44 & 72.1 & 17 & 27.9 \\
\hline Not at all & 53 & 86.9 & 8 & 13.1 \\
\hline
\end{tabular}

Agriculture issues. FFA advisors were asked the frequency they taught agriculture issues and the importance they place on teaching the topic to their students. Using a scale of 1-6 with 1 being "not important" and 6 "very important” the average rating of the importance of teaching agriculture issues was $4.86(\mathrm{SD}=1.06)$ (see Table 7). Five respondents (8.8\%) taught agriculture issues once a year. The topic was taught 2-3 times 
per year by 23 respondents (40.4\%), 4-5 times per year by 10 (17.5\%), and 6 or more times per year by 19 advisors (33.3\%) (see Table 7).

Agricultural science teachers were asked where they taught the topic of agriculture issues. Fifty-six teachers (91.8\%) taught agriculture issues in the classroom and 26 teachers (42.6\%) identified they taught agriculture issues at FFA meetings. Of the remaining teachers 25 (41\%) taught the topic at special training and 24 respondents (39.3\%) taught the topic one-on-one, two of the respondents (3.3\%) did not teach the topic (see Table 8).

Organizational structure. Agricultural science teachers were asked the frequency they taught the topic and the importance they place on teaching the topic to their students. Using a scale of 1-6 with 1 being "not important" and 6 "very important” the average rating of the importance of teaching organizational structure was $4.67(S D=1.01)$ (see Table 7). Ten respondents (17.9\%) taught organizational structure once a year. The topic was taught 2-3 times per year by 20 respondents (35.7\%), 4-5 times per year by 12 (21.4\%), and 6 or more times per year by 14 advisors (25\%) (see Table 7).

Respondents were asked where they taught the topic of organizational structure. Fifty-two respondents (83.9\%) taught organizational structure in the classroom and 35 teachers (56.5\%) identified they taught organizational structure at FFA meetings. Of the remaining respondents 24 (38.7\%) taught the topic at special training, 25 instructors (40.3\%) taught the topic one-on-one, and six respondents (9.7\%) did not teach the topic (see Table 8).

Agricultural education issues. FFA advisors were asked the frequency they taught the topic and the importance they place on teaching the topic to their students. Using a 
scale of 1-6 with 1 being "not important" and 6 "very important" the average rating of the importance of teaching agricultural education issues was $4.54(S D=1.09)$ (see Table 7). Five respondents (9.6\%) taught agricultural education issues once a year. The topic was taught 2-3 times per year by 24 respondents (46.2\%), 4-5 times per year by 12 instructors (23.1\%), and 6 or more times per year by 11 advisors (21.2\%) (see Table 7 ).

Agricultural science teachers were asked where they taught the topic of agricultural education issues. Forty-five teachers (73.8\%) taught agricultural education issues in the classroom and 21 teachers (34.4\%) identified they taught agricultural education issues at FFA meetings. Of the remaining teachers 15 (24.6\%) taught the topic at special training and 17 respondents (27.9\%) taught the topic one-on-one, eight of the respondents (13.1\%) did not teach the topic (see Table 8).

Leadership levels. FFA advisors were asked the frequency they taught the topic skill and the importance they place on teaching the topic to their students. Using a scale of 1-6 with 1 being "not important" and 6 "very important” the average rating of the importance of teaching leadership levels was $4.46(S D=1.24)$ (see Table 7). Eleven respondents (21.6\%) taught leadership levels once a year. The topic was taught 2-3 times per year by 19 respondents (37.3\%), 4-5 times per year by 10 (19.6\%), and 6 or more times per year by 11 advisors (21.6\%) (see Table 7).

Agricultural science teachers were asked where they taught the topic of leadership levels. Forty-one teachers (67.2\%) taught leadership levels in the classroom and 32 teachers (52.5\%) identified they taught leadership levels at FFA meetings. Of the remaining teachers 25 (41\%) taught the topic at special training and 22 respondents 
(36.1\%) taught the topic one-on-one, 10 of the respondents (16.4\%) did not teach the topic (see Table 8).

Leadership styles. Agricultural science teachers were asked the frequency they taught the topic and the importance they place on teaching the topic to their students. Using a scale of 1-6 with 1 being "not important" and 6 "very important" the average rating of the importance of teaching leadership styles was $4.46(\mathrm{SD}=1.13)$ (see Table 7). Eight respondents (16\%) taught leadership styles once a year. The topic was taught 2-3 times per year by 23 respondents (46\%), $4-5$ times per year by 11 (22\%), and 6 or more times per year by eight advisors (16\%) (see Table 7).

Respondents were asked where they taught the topic of leadership styles. Fortyfive respondents (84.9\%) taught leadership styles in the classroom and 24 teachers (45.3\%) identified they taught leadership styles at FFA meetings. Of the remaining respondents 29 (54.7\%) taught the topic at special training, 18 instructors (34\%) taught the topic one-on-one, and two respondents (3.8\%) did not teach the topic (see Table 8).

Learning styles. FFA advisors were asked the frequency they taught the topic and the importance they place on teaching the topic to their students. Using a scale of 1-6 with 1 being "not important" and 6 "very important” the average rating of the importance of teaching learning styles was $4.31(\mathrm{SD}=1.15)$ (see Table 7). Eleven respondents (21.2\%) taught learning styles once a year. The topic was taught 2-3 times per year by 22 respondents (42.3\%), 4-5 times per year by 12 instructors (23.1\%), and 6 or more times per year by seven advisors (13.5\%) (see Table 7).

Agricultural science teachers were asked where they taught the topic of learning styles. Forty-seven teachers (79.7\%) taught learning styles in the classroom and 14 
teachers (23.7\%) identified they taught learning styles at FFA meetings. Of the remaining teachers 20 (33.9\%) taught the topic at special training and 15 respondents (25.4\%) taught the topic one-on-one, eight of the respondents (13.6\%) did not teach the topic (see Table 8).

Importance, Frequency, and Location of Instruction of Leadership Ability Skills

Being a role model in your chapter. FFA advisors were asked the frequency they taught the skill and the importance they place on teaching the skill to their students.

Using a scale of 1-6 with 1 being "not important” and 6 "very important" the average rating of the importance of teaching being a role model in your chapter was 5.41 (SD $=0.86$ ) (see Table 9). Four respondents (6.8\%) taught being a role model in your chapter once a year. The skill was taught 2-3 times per year by 13 respondents (22\%), 4-5 times per year by 10 (16.9\%), and 6 or more times per year by 32 advisors (54.2\%) (see Table 9). 
Table 9

Importance \& Frequency of Leadership Ability Skills

\begin{tabular}{|c|c|c|c|c|c|c|c|c|c|c|}
\hline & \multicolumn{2}{|c|}{ Importance } & \multicolumn{8}{|c|}{ Frequency } \\
\hline & \multirow[b]{2}{*}{$M$} & \multirow[b]{2}{*}{$S D$} & \multicolumn{2}{|c|}{$\begin{array}{l}1 \text { time per } \\
\text { year }\end{array}$} & \multicolumn{4}{|c|}{$\begin{array}{c}\text { 2-3 times per } \\
\text { year }\end{array}$} & \multicolumn{2}{|c|}{$\begin{array}{l}6 \text { or more } \\
\text { times per } \\
\text { year }\end{array}$} \\
\hline & & & $N$ & $\%$ & $N$ & $\%$ & $N$ & $\%$ & $N$ & $\%$ \\
\hline $\begin{array}{l}\text { Being a role model in } \\
\text { your chapter }\end{array}$ & 5.41 & .86 & 4 & 6.8 & 13 & 22.0 & 10 & 16.9 & 32 & 54.2 \\
\hline Motivating members & 5.29 & .89 & 5 & 8.9 & 13 & 23.2 & 6 & 10.7 & 32 & 57.1 \\
\hline $\begin{array}{l}\text { Practicing proper } \\
\text { parliamentary } \\
\text { procedure }\end{array}$ & 5.26 & .85 & 0 & 0 & 9 & 15.3 & 13 & 22.0 & 37 & 62.7 \\
\hline $\begin{array}{l}\text { Creating partnerships } \\
\text { with community and } \\
\text { industry leaders }\end{array}$ & 5.26 & .99 & 8 & 14.0 & 14 & 24.6 & 10 & 17.5 & 25 & 43 \\
\hline $\begin{array}{l}\text { Running an effective } \\
\text { meeting }\end{array}$ & 5.17 & .85 & 3 & 5.2 & 14 & 24.1 & 14 & 24.1 & 27 & 46.6 \\
\hline Encouraging others & 5.05 & 1.02 & 6 & 10.7 & 18 & 32.1 & 10 & 17.9 & 22 & 39.3 \\
\hline $\begin{array}{l}\text { Delegating so that the } \\
\text { work gets done }\end{array}$ & 5.02 & 1.10 & 7 & 12.3 & 15 & 26.3 & 9 & 15.8 & 26 & 45.6 \\
\hline Leading an activity & 4.98 & 1.01 & 5 & 8.5 & 15 & 25.4 & 15 & 25.4 & 24 & 40.7 \\
\hline $\begin{array}{l}\text { Expressing your } \\
\text { opinion so that others } \\
\text { listen }\end{array}$ & 4.80 & 1.09 & 8 & 15.1 & 17 & 32.1 & 11 & 20.8 & 17 & 32.1 \\
\hline $\begin{array}{l}\text { Facilitating a meeting } \\
\text { or discussion }\end{array}$ & 4.78 & 1.07 & 5 & 8.8 & 12 & 21.1 & 17 & 29.8 & 23 & 40.4 \\
\hline $\begin{array}{l}\text { Characteristics of an } \\
\text { effective team player }\end{array}$ & 4.78 & 1.06 & 9 & 15.5 & 20 & 34.5 & 12 & 20.7 & 17 & 29.3 \\
\hline
\end{tabular}


Table 9 (Continued)

Importance \& Frequency of Leadership Ability Skills

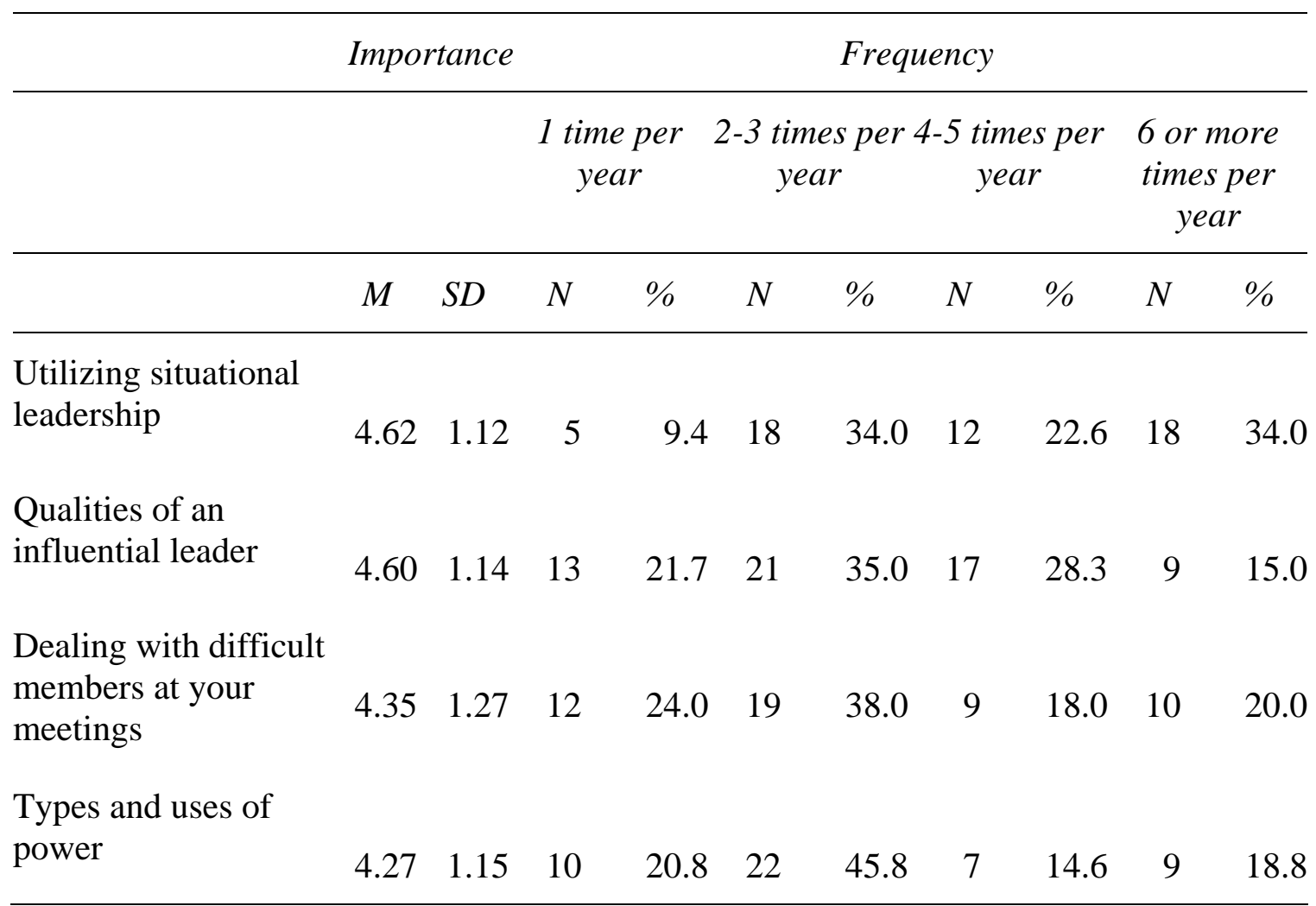

Importance Scale: 1 - Not Important 6 - Very Important

Agricultural science teachers were asked where they taught the skill of being a

role model in your chapter Forty-four teachers (71\%) taught being a role model in your chapter in both the classroom and at FFA meetings. Of the remaining teachers 41

(66.1\%) taught the skill at special training and 37 respondents (59.7\%) taught the skill one-on-one, two of the respondents (3.2\%) did not teach the skill (see Table 10). 
Table 10

Location Leadership Abilities are Taught

\begin{tabular}{|c|c|c|c|c|}
\hline & \multicolumn{2}{|c|}{ Not Taught } & \multicolumn{2}{|c|}{ Taught } \\
\hline & $N$ & $\%$ & $N$ & $\%$ \\
\hline \multicolumn{5}{|l|}{ Leading an activity } \\
\hline Classroom & 15 & 24.6 & 46 & 75.4 \\
\hline FFA Meeting & 20 & 32.8 & 41 & 67.2 \\
\hline Special Training & 27 & 44.3 & 34 & 55.7 \\
\hline One-on-one & 32 & 52.5 & 29 & 47.5 \\
\hline Not at all & 60 & 98.4 & 1 & 1.6 \\
\hline \multicolumn{5}{|c|}{ Facilitating a meeting or discussion } \\
\hline Classroom & 14 & 23.3 & 46 & 76.7 \\
\hline FFA Meeting & 16 & 26.7 & 44 & 73.3 \\
\hline Special Training & 23 & 38.3 & 37 & 61.7 \\
\hline One-on-one & 34 & 56.7 & 26 & 43.3 \\
\hline Not at all & 59 & 98.3 & 1 & 1.7 \\
\hline \multicolumn{5}{|c|}{ Utilizing situational leadership } \\
\hline Classroom & 18 & 30.5 & 41 & 69.5 \\
\hline FFA Meeting & 25 & 42.4 & 34 & 57.6 \\
\hline Special Training & 28 & 47.5 & 31 & 52.5 \\
\hline One-on-one & 36 & 61.0 & 23 & 39.0 \\
\hline Not at all & 55 & 93.2 & 4 & 6.8 \\
\hline \multicolumn{5}{|l|}{ Encouraging others } \\
\hline Classroom & 9 & 15.0 & 51 & 85.0 \\
\hline FFA Meeting & 23 & 38.3 & 37 & 61.7 \\
\hline Special Training & 29 & 48.3 & 31 & 51.7 \\
\hline One-on-one & 31 & 51.7 & 29 & 48.3 \\
\hline Not at all & 56 & 93.3 & 4 & 6.7 \\
\hline
\end{tabular}


Table 10 (Continued)

Location Leadership Abilities are Taught

\begin{tabular}{|c|c|c|c|c|}
\hline & \multicolumn{2}{|c|}{ Not Taught } & \multicolumn{2}{|c|}{ Taught } \\
\hline & $N$ & $\%$ & $N$ & $\%$ \\
\hline \multicolumn{5}{|c|}{ Practicing proper parliamentary procedure } \\
\hline Classroom & 10 & 16.4 & 51 & 83.6 \\
\hline FFA Meeting & 11 & 18.0 & 50 & 82.0 \\
\hline Special Training & 20 & 32.8 & 41 & 67.2 \\
\hline One-on-one & 34 & 55.7 & 27 & 44.3 \\
\hline Not at all & 60 & 98.4 & 1 & 1.6 \\
\hline \multicolumn{5}{|c|}{ Running an effective meeting } \\
\hline Classroom & 12 & 19.4 & 50 & 80.6 \\
\hline FFA Meeting & 8 & 12.9 & 54 & 87.1 \\
\hline Special Training & 23 & 37.1 & 39 & 62.9 \\
\hline One-on-one & 38 & 61.3 & 24 & 38.7 \\
\hline Not at all & 62 & 100.0 & & \\
\hline \multicolumn{5}{|c|}{ Delegating so that the work gets done } \\
\hline Classroom & 19 & 30.6 & 43 & 69.4 \\
\hline FFA Meeting & 21 & 33.9 & 41 & 66.1 \\
\hline Special Training & 26 & 41.9 & 36 & 58.1 \\
\hline One-on-one & 30 & 48.4 & 32 & 51.6 \\
\hline Not at all & 58 & 93.5 & 4 & 6.5 \\
\hline \multicolumn{5}{|c|}{$\begin{array}{l}\text { Creating partnerships with community } \\
\text { and industry leaders }\end{array}$} \\
\hline Classroom & 23 & 37.7 & 38 & 62.3 \\
\hline FFA Meeting & 19 & 31.1 & 42 & 68.9 \\
\hline Special Training & 25 & 41.0 & 36 & 59.0 \\
\hline One-on-one & 25 & 41.0 & 36 & 59.0 \\
\hline Not at all & 59 & 96.7 & 2 & 3.3 \\
\hline
\end{tabular}


Table 10 (Continued)

Location Leadership Abilities are Taught

\begin{tabular}{|c|c|c|c|c|}
\hline & \multicolumn{2}{|c|}{ Not Taught } & \multicolumn{2}{|c|}{ Taught } \\
\hline & $N$ & $\%$ & $N$ & $\%$ \\
\hline \multicolumn{5}{|l|}{ Motivating members } \\
\hline Classroom & 18 & 29.5 & 43 & 70.5 \\
\hline FFA Meeting & 13 & 21.3 & 48 & 78.7 \\
\hline Special Training & 21 & 34.4 & 40 & 65.6 \\
\hline One-on-one & 25 & 41.0 & 36 & 59.0 \\
\hline Not at all & 61 & 100.0 & & \\
\hline \multicolumn{5}{|c|}{$\begin{array}{l}\text { Dealing with difficult members at } \\
\text { your meetings }\end{array}$} \\
\hline Classroom & 46 & 76.7 & 14 & 23.3 \\
\hline FFA Meeting & 29 & 48.3 & 31 & 51.7 \\
\hline Special Training & 39 & 65.0 & 21 & 35.0 \\
\hline One-on-one & 30 & 50.0 & 30 & 50.0 \\
\hline Not at all & 50 & 83.3 & 10 & 16.7 \\
\hline \multicolumn{5}{|c|}{ Expressing your opinion so that others listen } \\
\hline Classroom & 15 & 24.6 & 46 & 75.4 \\
\hline FFA Meeting & 31 & 50.8 & 30 & 49.2 \\
\hline Special Training & 29 & 47.5 & 32 & 52.5 \\
\hline One-on-one & 30 & 49.2 & 31 & 50.8 \\
\hline Not at all & 53 & 86.9 & 8 & 13.1 \\
\hline \multicolumn{5}{|c|}{ Being a role model in your chapter } \\
\hline Classroom & 18 & 29.0 & 44 & 71.0 \\
\hline FFA Meeting & 18 & 29.0 & 44 & 71.0 \\
\hline Special Training & 21 & 33.9 & 41 & 66.1 \\
\hline One-on-one & 25 & 40.3 & 37 & 59.7 \\
\hline Not at all & 60 & 96.8 & 2 & 3.2 \\
\hline
\end{tabular}


Table 10 (Continued)

Location Leadership Abilities are Taught

\begin{tabular}{|c|c|c|c|c|}
\hline & \multicolumn{2}{|c|}{ Not Taught } & \multicolumn{2}{|c|}{ Taught } \\
\hline & $N$ & $\%$ & $N$ & $\%$ \\
\hline \multicolumn{5}{|c|}{$\begin{array}{l}\text { Characteristics of an effective team } \\
\text { player }\end{array}$} \\
\hline Classroom & 13 & 21.3 & 48 & 78.7 \\
\hline FFA Meeting & 25 & 41.0 & 36 & 59.0 \\
\hline Special Training & 23 & 37.7 & 38 & 62.3 \\
\hline One-on-one & 32 & 52.5 & 29 & 47.5 \\
\hline Not at all & 57 & 93.4 & 4 & 6.6 \\
\hline \multicolumn{5}{|c|}{ Types and uses of power } \\
\hline Classroom & 24 & 38.7 & 38 & 61.3 \\
\hline FFA Meeting & 42 & 67.7 & 20 & 32.3 \\
\hline Special Training & 42 & 67.7 & 20 & 32.3 \\
\hline One-on-one & 39 & 62.9 & 23 & 37.1 \\
\hline Not at all & 49 & 79.0 & 13 & 21.0 \\
\hline \multicolumn{5}{|c|}{ Qualities of an influential leader } \\
\hline Classroom & 6 & 10.0 & 54 & 90.0 \\
\hline FFA Meeting & 34 & 56.7 & 26 & 43.3 \\
\hline Special Training & 27 & 45.0 & 33 & 55.0 \\
\hline One-on-one & 41 & 68.3 & 19 & 31.7 \\
\hline Not at all & 60 & 100.0 & & \\
\hline
\end{tabular}

Motivating members. Agricultural science teachers were asked the frequency they taught the skill and the importance they place on teaching the skill to their students. Using a scale of 1-6 with 1 being "not important” and 6 "very important” the average rating of the importance of teaching motivating members was 5.29 (SD =.89) (see Table 
9). Five respondents (6.8\%) taught motivating members once a year. The skill was taught 2-3 times per year by 13 respondents (22\%), 4-5 times per year by 10 (16.9\%), and 6 or more times per year by 32 advisors (54.2\%) (see Table 9).

Respondents were asked where they taught the skill of motivating members. Forty-three respondents (70.5\%) taught motivating members in the classroom and 48 teachers (78.7\%) identified they taught motivating members at FFA meetings. Of the remaining respondents 40 (65.6\%) taught the skill at special training, 36 instructors (59\%) taught the skill one-on-one, and none of the respondents (0\%) did not teach the skill (see Table 10).

Practicing proper parliamentary procedure. Respondents were asked the frequency they taught the skill and the importance they place on teaching the skill to their students. Using a scale of 1-6 with 1 being "not important" and 6 "very important" the average rating of the importance of teaching practicing proper parliamentary procedure was $5.26(\mathrm{SD}=.85)$ (see Table 9). None of respondents ( $0 \%)$ taught practicing proper parliamentary procedure once a year. The skill was taught 2-3 times per year by nine respondents (15.3\%), 4-5 times per year by 13 (22\%), and 6 or more times per year by 37 advisors (62.7\%) (see Table 9).

FFA advisors were asked where they taught the skill of practicing proper parliamentary procedure. Fifty-one respondents (83.6\%) taught practicing proper parliamentary procedure in the classroom and 50 teachers (82\%) identified they taught practicing proper parliamentary procedure at FFA meetings. Of the remaining respondents 41 (67.2\%) taught the skill at special training, 27 instructors (44.3\%) taught the skill one-on-one, and one respondent (1.6\%) did not teach the skill (see Table 10). 
Creating partnerships with community and industry leaders. FFA advisors were asked the frequency they taught the skill and the importance they place on teaching the skill to their students. Using a scale of 1-6 with 1 being "not important" and 6 "very important” the average rating of the importance of teaching creating partnerships with community and industry leaders was 5.26 (SD =.99) (see Table 9). Eight respondents (14\%) taught creating partnerships with community and industry leaders once a year. The skill was taught 2-3 times per year by 14 respondents (24.6\%), $4-5$ times per year by 10 (17.5\%), and 6 or more times per year by 25 advisors (43\%) (see Table 9).

Agricultural science teachers were asked where they taught the skill of creating partnerships with community and industry leaders. Thirty-eight respondents (62.3\%) taught creating partnerships with community and industry leaders in the classroom and 42 teachers (68.9\%) identified they taught creating partnerships with community and industry leaders at FFA meetings. Of the remaining respondents 36 (59\%) taught the skill at both special training and one-on-one, and two respondents (3.3\%) did not teach the skill (see Table 10).

Running an effective meeting. Respondents were asked the frequency they taught the skill and the importance they place on teaching the skill to their students. Using a scale of 1-6 with 1 being "not important" and 6 "very important" the average rating of the importance of teaching running an effective meeting was $5.17(\mathrm{SD}=.85$ ) (see Table 9). Three respondents (5.2\%) taught running an effective meeting once a year. The skill was taught 2-3 times per year and 4-5 times per year by 14 respondents (24.1\%), and 6 or more times per year by 27 advisors (46.6\%) (see Table 9). 
FFA advisors were asked where they taught the skill of running an effective meeting. Fifty respondents (80.6\%) taught running an effective meeting in the classroom and 54 teachers (87.1\%) identified they taught running an effective meeting at FFA meetings. Of the remaining respondents 39 (62.9\%) taught the skill at special training, 24 instructors (38.7\%) taught the skill one-on-one, and none of the respondents (0\%) did not teach the skill (see Table 10).

Encouraging others. Respondents were asked the frequency they taught the skill and the importance they place on teaching the skill to their students. Using a scale of 1-6 with 1 being "not important" and 6 "very important" the average rating of the importance of teaching encouraging others was 5.05 (SD =1.02) (see Table 9). Six respondents (10.7\%) taught encouraging others once a year. The skill was taught 2-3 times per year by 18 respondents (32.1\%), 4-5 times per year by 10 (17.9\%), and 6 or more times per year by 22 advisors (39.3\%) (see Table 9).

Agricultural science teachers were asked where they taught the skill of encouraging others. Fifty-one respondents (85\%) taught encouraging others in the classroom and 37 teachers (61.7\%) identified they taught encouraging others at FFA meetings. Of the remaining respondents 31 (51.7\%) taught the skill in special training, 29 teachers (48.3\%) taught the skill one-on-one, and four respondents (6.7\%) did not teach the skill (see Table 10).

Delegating so that the work gets done. Agricultural science teachers were asked the frequency they taught the skill and the importance they place on teaching the skill to their students. Using a scale of 1-6 with 1 being "not important" and 6 "very important" the average rating of the importance of teaching delegating so that the work gets done 
was 5.02 (SD =1.10) (see Table 9). Seven respondents (12.3\%) taught delegating so that the work gets done once a year. The skill was taught 2-3 times per year by 15 respondents (26.3\%), 4-5 times per year by nine (15.8\%), and 6 or more times per year by 26 advisors (45.6\%) (see Table 9).

FFA advisors were asked where they taught the skill of delegating so that the work gets done. Forty-three respondents (69.4\%) taught delegating so that the work gets done in the classroom and 41 teachers (66.1\%) identified they taught delegating so that the work gets done at FFA meetings. Of the remaining respondents 36 (58.1\%) taught the skill in special training, 32 teachers (51.6\%) taught the skill one-on-one, and four respondents (6.5\%) did not teach the skill (see Table 10).

Leading an activity. Agricultural science teachers were asked the frequency they taught the skill and the importance they place on teaching the skill to their students. Using a scale of 1-6 with 1 being "not important” and 6 "very important" the average rating of the importance of teaching leading an activity was $4.98(\mathrm{SD}=1.01$ ) (see Table 9). Five respondents (8.5\%) taught leading an activity once a year. The skill was taught 2-3 times per year by 15 respondents (25.4\%), 4-5 times per year by 15 (25.4\%), and 6 or more times per year by 24 advisors (40.7\%) (see Table 9).

Respondents were asked where they taught the skill of leading an activity. Fortysix respondents (75.4\%) taught leading an activity in the classroom and 41 teachers (67.2\%) identified they taught leading an activity at FFA meetings. Of the remaining respondents 34 (55.7\%) taught the skill in special training, 39 teachers (47.5\%) taught the skill one-on-one, and one respondent (1.6\%) did not teach the skill (see Table 10). 
Expressing your opinion so that others listen. Respondents were asked the frequency they taught the skill and the importance they place on teaching the skill to their students. Using a scale of 1-6 with 1 being "not important" and 6 "very important" the average rating of the importance of teaching expressing your opinion so that others listen was 4.80 (SD =1.09) (see Table 9). Eight respondents (15.1\%) taught expressing your opinion so that others listen once a year. The skill was taught 2-3 times per year by 17 respondents (32.1\%), 4-5 times per year by 11 (20.8\%), and 6 or more times per year by 17 advisors (32.1\%) (see Table 9).

FFA advisors were asked where they taught the skill of expressing your opinion so that others listen. Forty-six respondents (75.4\%) taught expressing your opinion so that others listen in the classroom and 30 teachers (49.2\%) identified they taught expressing your opinion so that others listen at FFA meetings. Of the remaining respondents 32 (52.5\%) taught the skill in special training, 31 teachers (50.8\%) taught the skill one-onone, and eight respondents (13.1\%) did not teach the skill (see Table 10).

Facilitating a meeting or discussion. FFA advisors were asked the frequency they taught the skill and the importance they place on teaching the skill to their students. Using a scale of 1-6 with 1 being "not important" and 6 "very important" the average rating of the importance of teaching facilitating a meeting or discussion was 4.78 (SD $=1.07$ ) (see Table 9). Five respondents (8.8\%) taught facilitating a meeting or discussion once a year. The skill was taught 2-3 times per year by 12 respondents (21.1\%), 4-5 times per year by 17 (29.8\%), and 6 or more times per year by 23 advisors (40.4\%) (see Table 9). 
Agricultural science instructors were asked where they taught the skill of facilitating a meeting or discussion. Forty-six respondents (76.7\%) taught facilitating a meeting or discussion in the classroom and 44 teachers (73.3\%) identified they taught facilitating a meeting or discussion at FFA meetings. Of the remaining respondents 37 (61.7\%) taught the skill in special training, 26 teachers (43.3\%) taught the skill one-onone, and one respondent (1.7\%) did not teach the skill (see Table 10).

Characteristics of an effective team player. Respondents were asked the frequency they taught the topic and the importance they place on teaching the topic to their students. Using a scale of 1-6 with 1 being "not important" and 6 "very important" the average rating of the importance of teaching characteristics of an effective team player was 4.78 (SD =1.06) (see Table 9). Nine respondents (15.5\%) taught characteristics of an effective team player once a year. The topic was taught 2-3 times per year by 20 respondents (34.5\%), 4-5 times per year by 12 (20.7\%), and 6 or more times per year by 17 advisors (29.3\%) (see Table 9).

FFA advisors were asked where they taught the topic of characteristics of an effective team player. Forty-eight respondents (78.7\%) taught characteristics of an effective team player in the classroom and 36 teachers (59\%) identified they taught characteristics of an effective team player at FFA meetings. Of the remaining respondents 38 (62.3\%) taught the topic in special training, 29 teachers (47.5\%) taught the topic one-on-one, and four respondents (6.6\%) did not teach the topic (see Table 10).

Utilizing situational leadership. FFA advisors were asked the frequency they taught the skill and the importance they place on teaching the skill to their students. Using a scale of 1-6 with 1 being "not important" and 6 "very important” the average 
rating of the importance of teaching utilizing situational leadership was 4.62 (SD =1.12) (see Table 9). Five respondents (9.4\%) taught utilizing situational leadership once a year. The skill was taught 2-3 times per year by 18 respondents (34\%), $4-5$ times per year by 12 (22.6\%), and 6 or more times per year by 18 advisors (34\%) (see Table 9).

Respondents were asked where they taught the skill of utilizing situational leadership. Forty-one respondents (69.5\%) taught utilizing situational leadership in the classroom and 34 teachers (57.6\%) identified they taught utilizing situational leadership at FFA meetings. Of the remaining respondents 31 (52.5\%) taught the skill in special training, 23 teachers (39\%) taught the skill one-on-one, and four respondents (6.8\%) did not teach the skill (see Table 10).

Qualities of an influential leader. Agricultural science teachers were asked the frequency they taught the topic and the importance they place on teaching the topic to their students. Using a scale of 1-6 with 1 being "not important" and 6 "very important" the average rating of the importance of teaching qualities of an influential leader was 4.60 ( $\mathrm{SD}=1.14)$ (see Table 9). Thirteen respondents (21.7\%) taught qualities of an influential leader once a year. The topic was taught 2-3 times per year by 21 respondents (35\%), 4-5 times per year by 17 (28.3\%), and 6 or more times per year by 9 advisors (15\%) (see Table 9).

FFA advisors were asked where they taught the topic of qualities of an influential leader. Fifty-four respondents (90\%) taught qualities of an influential leader in the classroom and 26 teachers (43.3\%) identified they taught qualities of an influential leader at FFA meetings. Of the remaining respondents 33 (55\%) taught the topic in special 
training, 19 teachers (31.7\%) taught the topic one-on-one, and none of the respondents (0\%) did not teach the topic (see Table 10).

Dealing with difficult members at your meetings. Respondents were asked the frequency they taught the skill and the importance they place on teaching the skill to their students. Using a scale of 1-6 with 1 being "not important” and 6 "very important” the average rating of the importance of teaching dealing with difficult members at your meetings was 4.35 (SD =1.27) (see Table 9). Twelve respondents (24\%) taught dealing with difficult members at your meetings once a year. The skill was taught 2-3 times per year by 19 respondents (38\%), 4-5 times per year by nine (18\%), and 6 or more times per year by 10 advisors (20\%) (see Table 9).

Agricultural science teachers were asked where they taught the skill of dealing with difficult members at your meetings. Fourteen respondents (23.3\%) taught dealing with difficult members at your meetings in the classroom and 31 teachers (51.7\%) identified they taught dealing with difficult members at your meetings at FFA meetings. Of the remaining respondents 21 (35\%) taught the skill in special training, 30 teachers (50\%) taught the skill one-on-one, and 10 respondents (16.7\%) did not teach the skill (see Table 10).

Types and uses of power. FFA advisors were asked the frequency they taught the topic and the importance they place on teaching the topic to their students. Using a scale of 1-6 with 1 being “not important” and 6 "very important” the average rating of the importance of teaching types and uses of power was 4.27 ( $\mathrm{SD}=1.15)$ (see Table 9). Ten respondents (20.8\%) taught types and uses of power once a year. The topic was taught 2- 
3 times per year by 22 respondents (45.8\%), 4-5 times per year by seven (14.6\%), and 6 or more times per year by nine advisors (18.8\%) (see Table 9).

Agricultural science teachers were asked where they taught the topic of types and uses of power. Thirty-eight respondents (61.3\%) taught types and uses of power in the classroom and 20 teachers (32.3\%) identified they taught types and uses of power at both FFA meetings and in special training, 23 teachers (37.1\%) taught the topic one-on-one, and 13 respondents (21\%) did not teach the topic (see Table 10). Importance, Frequency, and Location of Instruction of Oral Communication Skills Delivering a speech. Agricultural science teachers were asked the frequency they taught the skill and the importance they place on teaching the skill to their students. Using a scale of 1-6 with 1 being "not important” and 6 "very important” the average rating of the importance of teaching delivering a speech was 5.32 (SD =.97) (see Table 11). Four respondents (6.6\%) taught delivering a speech once a year. The skill was taught 2-3 times per year by 14 respondents (23\%), 4-5 times per year by 17 (27.9\%), and 6 or more times per year by 26 advisors (42.6\%) (see Table 11$)$. 
Table 11

Importance \& Frequency of Oral Communication Skills

\begin{tabular}{|c|c|c|c|c|c|c|c|c|c|c|}
\hline & \multicolumn{2}{|c|}{ Importance } & \multicolumn{8}{|c|}{ Frequency } \\
\hline & \multirow[b]{2}{*}{$M$} & \multirow[b]{2}{*}{$S D$} & \multicolumn{2}{|c|}{$\begin{array}{l}1 \text { time per } \\
\text { year }\end{array}$} & \multicolumn{4}{|c|}{$\begin{array}{c}\text { 2-3 times per 4-5 times per } \\
\text { year } \quad \text { year }\end{array}$} & \multicolumn{2}{|c|}{$\begin{array}{c}6 \text { or more } \\
\text { times per } \\
\text { year }\end{array}$} \\
\hline & & & $N$ & $\%$ & $N$ & $\%$ & $N$ & $\%$ & $N$ & $\%$ \\
\hline Delivering a speech & 5.32 & .97 & 4 & 6.6 & 14 & 23.0 & 17 & 27.9 & 26 & 42.6 \\
\hline $\begin{array}{l}\text { Giving clear } \\
\text { directions }\end{array}$ & 5.08 & 1.18 & 8 & 13.6 & 14 & 23.7 & 11 & 18.6 & 26 & 44.1 \\
\hline $\begin{array}{l}\text { Presenting powerful } \\
\text { ceremonies }\end{array}$ & 4.77 & 1.04 & 11 & 19.6 & 18 & 32.1 & 11 & 19.6 & 16 & 28.6 \\
\hline $\begin{array}{l}\text { Developing and } \\
\text { delivering powerful } \\
\text { key messages }\end{array}$ & 4.67 & 1.14 & 10 & 19.6 & 17 & 33.3 & 12 & 23.5 & 12 & 23.5 \\
\hline $\begin{array}{l}\text { Utilizing effective } \\
\text { telephone etiquette }\end{array}$ & 4.60 & 1.16 & 14 & 25.9 & 21 & 38.9 & 7 & 13.0 & 12 & 22.2 \\
\hline $\begin{array}{l}\text { Using audio-visual } \\
\text { equipment in your } \\
\text { presentations }\end{array}$ & 4.55 & 1.23 & 4 & 8.2 & 16 & 32.7 & 8 & 16.3 & 21 & 42.9 \\
\hline $\begin{array}{l}\text { Establishing and } \\
\text { maintaining } \\
\text { conversations }\end{array}$ & 4.51 & 1.29 & 6 & 13.3 & 19 & 42.2 & 7 & 15.6 & 13 & 28.9 \\
\hline Introducing a speaker & 4.43 & 1.27 & 16 & 28.6 & 19 & 33.9 & 9 & 16.1 & 12 & 21.4 \\
\hline Presenting awards & 4.43 & 1.27 & 16 & 27.1 & 25 & 42.4 & 7 & 11.9 & 11 & 18.6 \\
\hline $\begin{array}{l}\text { Creating welcoming } \\
\text { remarks }\end{array}$ & 4.34 & 1.26 & 16 & 30.2 & 21 & 39.6 & 9 & 17.0 & 7 & 13.2 \\
\hline $\begin{array}{l}\text { Using a microphone } \\
\text { effectively }\end{array}$ & 3.82 & 1.43 & 18 & 36.0 & 24 & 48.0 & 2 & 4.0 & 6 & 12.0 \\
\hline
\end{tabular}

Importance Scale: 1 - Not Important 6 - Very Important 
FFA advisors were asked where they taught the skill of delivering a speech. Fiftytwo respondents (85.2\%) taught delivering a speech in the classroom and 40 teachers (65.6\%) identified they taught delivering a speech at FFA meetings, 34 advisors (55.7\%) taught the skill in special training, 38 teachers (62.3\%) taught the skill one-on-one, and none of the respondents ( $0 \%$ ) did not teach the skill (see Table 12 ).

Table 12

Location Oral Communication Skills are Taught

\begin{tabular}{lcccc}
\hline & \multicolumn{2}{c}{ Not Taught } & \multicolumn{2}{c}{ Taught } \\
\cline { 2 - 5 } & $N$ & $\%$ & $N$ & $\%$ \\
\hline Introducing a speaker & & & 31 & 52.5 \\
Classroom & 31 & 52.5 & 28 & 47.5 \\
FFA Meeting & 36 & 61.0 & 23 & 39.0 \\
Special Training & 35 & 59.3 & 24 & 40.7 \\
One-on-one & 55 & 93.2 & 4 & 6.8 \\
Not at all & & & & \\
Giving clear directions & 12 & 19.7 & 49 & 80.3 \\
Classroom & 30 & 49.2 & 31 & 50.8 \\
FFA Meeting & 33 & 54.1 & 28 & 45.9 \\
Special Training & 56 & 65.6 & 21 & 34.4 \\
One-on-one & & 91.8 & 5 & \\
Not at all & & & & \\
\hline
\end{tabular}


Table 12 (Continued)

Location Oral Communication Skills are Taught

\begin{tabular}{|c|c|c|c|c|}
\hline & \multicolumn{2}{|c|}{ Not Taught } & \multicolumn{2}{|c|}{ Taught } \\
\hline & $N$ & $\%$ & $N$ & $\%$ \\
\hline \multicolumn{5}{|l|}{ Presenting awards } \\
\hline Classroom & 37 & 60.7 & 24 & 39.3 \\
\hline FFA Meeting & 26 & 42.6 & 35 & 57.4 \\
\hline Special Training & 28 & 45.9 & 33 & 54.1 \\
\hline One-on-one & 35 & 57.4 & 26 & 42.6 \\
\hline Not at all & 58 & 95.1 & 3 & 4.9 \\
\hline \multicolumn{5}{|c|}{$\begin{array}{l}\text { Establishing and maintaining } \\
\text { conversations }\end{array}$} \\
\hline Classroom & 25 & 42.4 & 34 & 57.6 \\
\hline FFA Meeting & 36 & 61.0 & 23 & 39.0 \\
\hline Special Training & 36 & 61.0 & 23 & 39.0 \\
\hline One-on-one & 38 & 64.4 & 21 & 35.6 \\
\hline Not at all & 45 & 76.3 & 14 & 23.7 \\
\hline \multicolumn{5}{|c|}{ Using a microphone effectively } \\
\hline Classroom & 48 & 78.7 & 13 & 21.3 \\
\hline FFA Meeting & 38 & 62.3 & 23 & 37.7 \\
\hline Special Training & 35 & 57.4 & 26 & 42.6 \\
\hline One-on-one & 37 & 60.7 & 24 & 39.3 \\
\hline Not at all & 46 & 75.4 & 15 & 24.6 \\
\hline
\end{tabular}


Table 12 (Continued)

Location Oral Communication Skills are Taught

\begin{tabular}{|c|c|c|c|c|}
\hline & \multicolumn{2}{|c|}{ Not Taught } & \multicolumn{2}{|c|}{ Taught } \\
\hline & $N$ & $\%$ & $N$ & $\%$ \\
\hline \multicolumn{5}{|l|}{ Delivering a speech } \\
\hline Classroom & 9 & 14.8 & 52 & 85.2 \\
\hline FFA Meeting & 21 & 34.4 & 40 & 65.6 \\
\hline Special Training & 27 & 44.3 & 34 & 55.7 \\
\hline One-on-one & 23 & 37.7 & 38 & 62.3 \\
\hline Not at all & 61 & 100.0 & & \\
\hline \multicolumn{5}{|c|}{ Creating welcoming remarks } \\
\hline Classroom & 38 & 63.3 & 22 & 36.7 \\
\hline FFA Meeting & 36 & 60.0 & 24 & 40.0 \\
\hline Special Training & 41 & 68.3 & 19 & 31.7 \\
\hline One-on-one & 29 & 48.3 & 31 & 51.7 \\
\hline Not at all & 53 & 88.3 & 7 & 11.7 \\
\hline \multicolumn{5}{|c|}{$\begin{array}{l}\text { Utilizing effective telephone } \\
\text { etiquette }\end{array}$} \\
\hline Classroom & 20 & 32.8 & 41 & 67.2 \\
\hline FFA Meeting & 47 & 77.0 & 14 & 23.0 \\
\hline Special Training & 32 & 52.5 & 29 & 47.5 \\
\hline One-on-one & 32 & 52.5 & 29 & 47.5 \\
\hline Not at all & 53 & 86.9 & 8 & 13.1 \\
\hline
\end{tabular}


Table 12 (Continued)

Location Oral Communication Skills are Taught

\begin{tabular}{|c|c|c|c|c|}
\hline & \multicolumn{2}{|c|}{ Not Taught } & \multicolumn{2}{|c|}{ Taught } \\
\hline & $N$ & $\%$ & $N$ & $\%$ \\
\hline \multicolumn{5}{|c|}{$\begin{array}{l}\text { Using audio-visual equipment in } \\
\text { your presentations }\end{array}$} \\
\hline Classroom & 21 & 34.4 & 40 & 65.6 \\
\hline FFA Meeting & 39 & 63.9 & 22 & 36.1 \\
\hline Special Training & 41 & 67.2 & 20 & 32.8 \\
\hline One-on-one & 36 & 59.0 & 25 & 41.0 \\
\hline Not at all & 51 & 83.6 & 10 & 16.4 \\
\hline \multicolumn{5}{|c|}{$\begin{array}{l}\text { Developing and delivering } \\
\text { powerful key messages }\end{array}$} \\
\hline Classroom & 39 & 65.0 & 21 & 35.0 \\
\hline FFA Meeting & 32 & 53.3 & 28 & 46.7 \\
\hline Special Training & 34 & 56.7 & 26 & 43.3 \\
\hline One-on-one & 27 & 45.0 & 33 & 55.0 \\
\hline Not at all & 51 & 85.0 & 9 & 15.0 \\
\hline \multicolumn{5}{|c|}{ Presenting powerful ceremonies } \\
\hline Classroom & 33 & 54.1 & 28 & 45.9 \\
\hline FFA Meeting & 23 & 37.7 & 38 & 62.3 \\
\hline Special Training & 24 & 39.3 & 37 & 60.7 \\
\hline One-on-one & 35 & 57.4 & 26 & 42.6 \\
\hline Not at all & 58 & 95.1 & 3 & 4.9 \\
\hline
\end{tabular}


Giving clear directions. Respondents were asked the frequency they taught the skill and the importance they place on teaching the skill to their students. Using a scale of 1-6 with 1 being "not important” and 6 "very important” the average rating of the importance of teaching giving clear directions was $5.08(\mathrm{SD}=1.18)$ (see Table 11). Eight respondents (13.6\%) taught giving clear directions once a year. The skill was taught 2-3 times per year by 14 respondents (23.7\%), $4-5$ times per year by 11 (18.6\%), and 6 or more times per year by 26 advisors (44.1\%) (see Table 11).

Agriculture science instructors were asked where they taught the skill of giving clear directions. Forty-nine respondents (80.3\%) taught giving clear directions in the classroom and 31 teachers (50.8\%) identified they taught giving clear directions at FFA meetings, 28 advisors (45.9\%) taught the skill in special training, 21 teachers (34.4\%) taught the skill one-on-one, and 5 respondents (8.2\%) did not teach the skill (see Table 12).

Presenting powerful ceremonies. FFA advisors were asked the frequency they taught the skill and the importance they place on teaching the skill to their students. Using a scale of 1-6 with 1 being "not important" and 6 "very important" the average rating of the importance of teaching presenting powerful ceremonies was $4.77(\mathrm{SD}=1.04)$ (see Table 11). Eleven respondents (19.6\%) taught presenting powerful ceremonies once a year. The skill was taught 2-3 times per year by 18 respondents (32.1\%), 4-5 times per year by 11 (19.6\%), and 6 or more times per year by 16 advisors (28.6\%) (see Table 11).

Respondents were asked where they taught the skill of presenting powerful ceremonies. Twenty-eight respondents (45.9\%) taught presenting powerful ceremonies in the classroom and 38 teachers (62.3\%) identified they taught presenting powerful 
ceremonies at FFA meetings, 37 advisors (60.7\%) taught the skill in special training, 26 teachers (42.6\%) taught the skill one-on-one, and three respondents (4.9\%) did not teach the skill (see Table 12).

Developing and delivering powerful key messages. Respondents were asked the frequency they taught the skill and the importance they place on teaching the skill to their students. Using a scale of 1-6 with 1 being "not important” and 6 "very important” the average rating of the importance of teaching developing and delivering powerful key messages was $4.67(\mathrm{SD}=1.16)$ (see Table 11$)$. Ten respondents $(19.6 \%)$ taught developing and delivering powerful key messages once a year. The skill was taught 2-3 times per year by 17 respondents (33.3\%), 4-5 times per year and 6 or more times per year by 12 (23.5\%) (see Table 11).

Agricultural science teachers were asked where they taught the skill of developing and delivering powerful key messages. Twenty-one respondents (35\%) taught developing and delivering powerful key messages in the classroom and 28 teachers (46.7\%) identified they taught developing and delivering powerful key messages at FFA meetings, 26 advisors (43.3\%) taught the skill in special training, 33 teachers (55\%) taught the skill one-on-one, and nine respondents (15\%) did not teach the skill (see Table 12).

Utilizing effective telephone etiquette. FFA advisors were asked the frequency they taught the skill and the importance they place on teaching the skill to their students. Using a scale of 1-6 with 1 being "not important” and 6 "very important” the average rating of the importance of teaching utilizing effective telephone etiquette was 4.60 (SD =1.16) (see Table 11). Fourteen respondents (25.9\%) taught utilizing effective telephone etiquette once a year. The skill was taught 2-3 times per year by 21 respondents (38.9\%), 
4-5 times per year by seven (13\%), and 6 or more times per year by 12 advisors (22.2\%) (see Table 11).

Respondents were asked where they taught the skill of utilizing effective telephone etiquette. Forty-one respondents (67.2\%) taught utilizing effective telephone etiquette in the classroom and 14 teachers (23\%) identified they utilizing effective telephone etiquette taught at FFA meetings, 29 advisors (47.5\%) taught the skill in both special training and one-on-one, and eight respondents (13.1\%) did not teach the skill (see Table 12).

Using audio-visual equipment in your presentations. Respondents were asked the frequency they taught the skill and the importance they place on teaching the skill to their students. Using a scale of 1-6 with 1 being "not important” and 6 "very important” the average rating of the importance of teaching using audio-visual equipment in your presentations was 4.55 (SD =1.23) (see Table 11). Four respondents (8.2\%) taught using audio-visual equipment in your presentations once a year. The skill was taught 2-3 times per year by 16 respondents (32.7\%), 4-5 times per year by eight (16.3\%), and 6 or more times per year by 21 advisors (42.9\%) (see Table 11).

Agricultural science instructors were asked where they taught the skill of using audio-visual equipment in your presentations. Forty respondents (65.6\%) taught using audio-visual equipment in your presentations in the classroom and 22 teachers (36.1\%) identified they taught using audio-visual equipment in your presentations at FFA meetings, 20 advisors (32.8\%) taught the skill in special training, 25 teachers (41\%) taught the skill one-on-one, and 10 respondents (16.4\%) did not teach the skill (see Table 12). 
Establishing and maintaining conversations. Agricultural science instructors were asked the frequency they taught the skill and the importance they place on teaching the skill to their students. Using a scale of 1-6 with 1 being "not important" and 6 "very important” the average rating of the importance of teaching establishing and maintaining conversations was 4.51 (SD =1.29) (see Table 11). Six respondents (13.3\%) taught establishing and maintaining conversations once a year. The skill was taught 2-3 times per year by 19 respondents (42.2\%), 4-5 times per year by seven (15.6\%), and 6 or more times per year by 13 advisors (28.9\%) (see Table 11$)$.

FFA advisors were asked where they taught the skill of establishing and maintaining conversations. Thirty-four respondents (57.6\%) taught establishing and maintaining conversations in the classroom and 23 teachers (39\%) identified they taught establishing and maintaining conversations at both FFA meetings and in special training, 21 teachers (35.6\%) taught the skill one-on-one, and 14 respondents (23.7\%) did not teach the skill (see Table 12).

Introducing a speaker. Respondents were asked the frequency they taught the skill and the importance they place on teaching the skill to their students. Using a scale of 1-6 with 1 being "not important" and 6 "very important" the average rating of the importance of teaching introducing a speaker was 4.43 (SD =1.27) (see Table 11). Sixteen respondents (28.6\%) taught introducing a speaker once a year. The skill was taught 2-3 times per year by 19 respondents (33.9\%), 4-5 times per year by nine (16.1\%), and 6 or more times per year by 12 advisors (21.4\%) (see Table 11).

FFA advisors were asked where they taught the skill of introducing a speaker. Thirty-one respondents (52.5\%) taught introducing a speaker in the classroom and 28 
teachers (47.5\%) identified they taught introducing a speaker at FFA meetings, 23 advisors (39\%) taught the skill in special training, 24 teachers (40.7\%) taught the skill one-on-one, and four respondents (6.8\%) did not teach the skill (see Table 12).

Presenting awards. Agricultural science teachers were asked the frequency they taught the skill and the importance they place on teaching the skill to their students. Using a scale of 1-6 with 1 being "not important" and 6 "very important" the average rating of the importance of teaching presenting awards was 4.43 (SD =1.27) (see Table 11). Sixteen respondents (27.1\%) taught presenting awards once a year. The skill was taught 2-3 times per year by 25 respondents (42.4\%), 4-5 times per year by seven (11.9\%), and 6 or more times per year by 11 advisors (18.6\%) (see Table 11).

FFA advisors were asked where they taught the skill of presenting awards. Twenty-four respondents (39.3\%) taught presenting awards in the classroom and 35 teachers (57.4\%) identified they taught presenting awards at FFA meetings, 33 advisors (54.1\%) taught the skill in special training, 26 teachers (42.6\%) taught the skill one-onone, and three respondents (4.9\%) did not teach the skill (see Table 12).

Creating welcoming remarks. Respondents were asked the frequency they taught the skill and the importance they place on teaching the skill to their students. Using a scale of 1-6 with 1 being "not important" and 6 "very important" the average rating of the importance of teaching creating welcoming remarks was 4.34 ( $\mathrm{SD}=1.26)$ (see Table 11). Sixteen respondents (30.2\%) taught creating welcoming remarks once a year. The skill was taught 2-3 times per year by 21 respondents (39.6\%), $4-5$ times per year by nine (17\%), and 6 or more times per year by seven advisors (13.2\%) (see Table 11). 
Agricultural science teachers were asked where they taught the skill of creating welcoming remarks. Twenty-two respondents (36.7\%) taught creating welcoming remarks in the classroom and 24 teachers (40\%) identified they taught creating welcoming remarks at FFA meetings, 19 advisors (31.7\%) taught the skill in special training, 31 teachers (51.7\%) taught the skill one-on-one, and seven respondents $(11.7 \%)$ did not teach the skill (see Table 12).

Using a microphone effectively. FFA advisors were asked the frequency they taught the skill and the importance they place on teaching the skill to their students. Using a scale of 1-6 with 1 being "not important” and 6 "very important” the average rating of the importance of teaching using a microphone effectively was 3.82 (SD =1.43) (see Table 11). Eighteen respondents (36\%) taught using a microphone effectively once a year. The skill was taught 2-3 times per year by 24 respondents (48\%), 4-5 times per year by two (4\%), and 6 or more times per year by six advisors (12\%) (see Table 11). Agricultural science teachers were asked where they taught the skill of using a microphone effectively. Thirteen respondents (21.3\%) taught using a microphone effectively in the classroom and 23 teachers (37.3\%) identified they taught using a microphone effectively at FFA meetings, 26 advisors (42.6\%) taught the skill in special training, 24 teachers (39.3\%) taught the skill one-on-one, and 15 respondents (24.6\%) did not teach the skill (see Table 12). Importance, Frequency, and Location of Instruction of Personal Skills

Being responsible. Agricultural science teachers were asked the frequency they taught the topic and the importance they place on teaching the topic to their students. Using a scale of 1-6 with 1 being "not important” and 6 "very important” the average 
rating of the importance of teaching being responsible was $5.49(\mathrm{SD}=.87)$ (see Table 13). Six respondents (10.2\%) taught being responsible once a year. The topic was taught 2-3 times per year by eight respondents (48\%), 4-5 times per year by three (4\%), and 6 or more times per year by 42 advisors (71.2\%) (see Table 13).

Table 13

Importance \& Frequency of Personal Skills

\begin{tabular}{|c|c|c|c|c|c|c|c|c|c|c|}
\hline & \multicolumn{4}{|c|}{ Importance } & \multicolumn{4}{|c|}{ Frequency } & & \\
\hline & & & $1 \mathrm{ti}$ & $\begin{array}{l}\text { e per } \\
\text { ar }\end{array}$ & $\begin{array}{r}2-3 t \\
y\end{array}$ & $\begin{array}{l}\text { les per } \\
\text { ar }\end{array}$ & $\begin{array}{r}4-5 \text { ti } \\
y\end{array}$ & $\begin{array}{l}\text { es per } \\
\text { ar }\end{array}$ & $\begin{array}{r}6 \text { or } \\
\text { tim } \\
y\end{array}$ & $\begin{array}{l}\text { nore } \\
\text { per } \\
\text { ar }\end{array}$ \\
\hline & $M$ & $S D \Lambda$ & $N$ & $\%$ & $N$ & $\%$ & $N$ & $\%$ & $N$ & $\%$ \\
\hline Being responsible & 5.49 & .87 & 6 & 10.2 & 8 & 13.6 & 3 & 5.1 & 42 & 71.2 \\
\hline Effective listening & 5.34 & .88 & 4 & 6.9 & 13 & 22.4 & 10 & 17.2 & 31 & 53.4 \\
\hline $\begin{array}{l}\text { Improving self } \\
\text { confidence }\end{array}$ & 5.09 & .94 & 7 & 12.3 & 20 & 35.1 & 6 & 10.5 & 24 & 42.1 \\
\hline $\begin{array}{l}\text { Managing your time } \\
\text { effectively }\end{array}$ & 5.08 & .96 & 10 & 17.2 & 17 & 29.3 & 9 & 15.5 & 22 & 37.9 \\
\hline $\begin{array}{l}\text { Creating a great first } \\
\text { impression }\end{array}$ & 5.04 & .96 & 9 & 17.0 & 13 & 24.5 & 15 & 28.3 & 16 & 30.2 \\
\hline $\begin{array}{l}\text { Relationship } \\
\text { building }\end{array}$ & 5.03 & 1.03 & 4 & 7.3 & 24 & 43.6 & 8 & 14.5 & 19 & 34.5 \\
\hline Managing your life & 4.94 & 1.16 & 8 & 15.1 & 14 & 26.4 & 10 & 18.9 & 21 & 39.6 \\
\hline $\begin{array}{l}\text { Accepting } \\
\text { constructive } \\
\text { criticism }\end{array}$ & 4.90 & 1.09 & 9 & 16.4 & 19 & 34.5 & 14 & 25.5 & 13 & 23.6 \\
\hline $\begin{array}{l}\text { Keys to personal } \\
\text { success }\end{array}$ & 4.88 & 1.14 & 8 & 14.0 & 22 & 38.6 & 10 & 17.5 & 17 & 29.8 \\
\hline
\end{tabular}


Table 13 (Continued)

Importance \& Frequency of Personal Skills

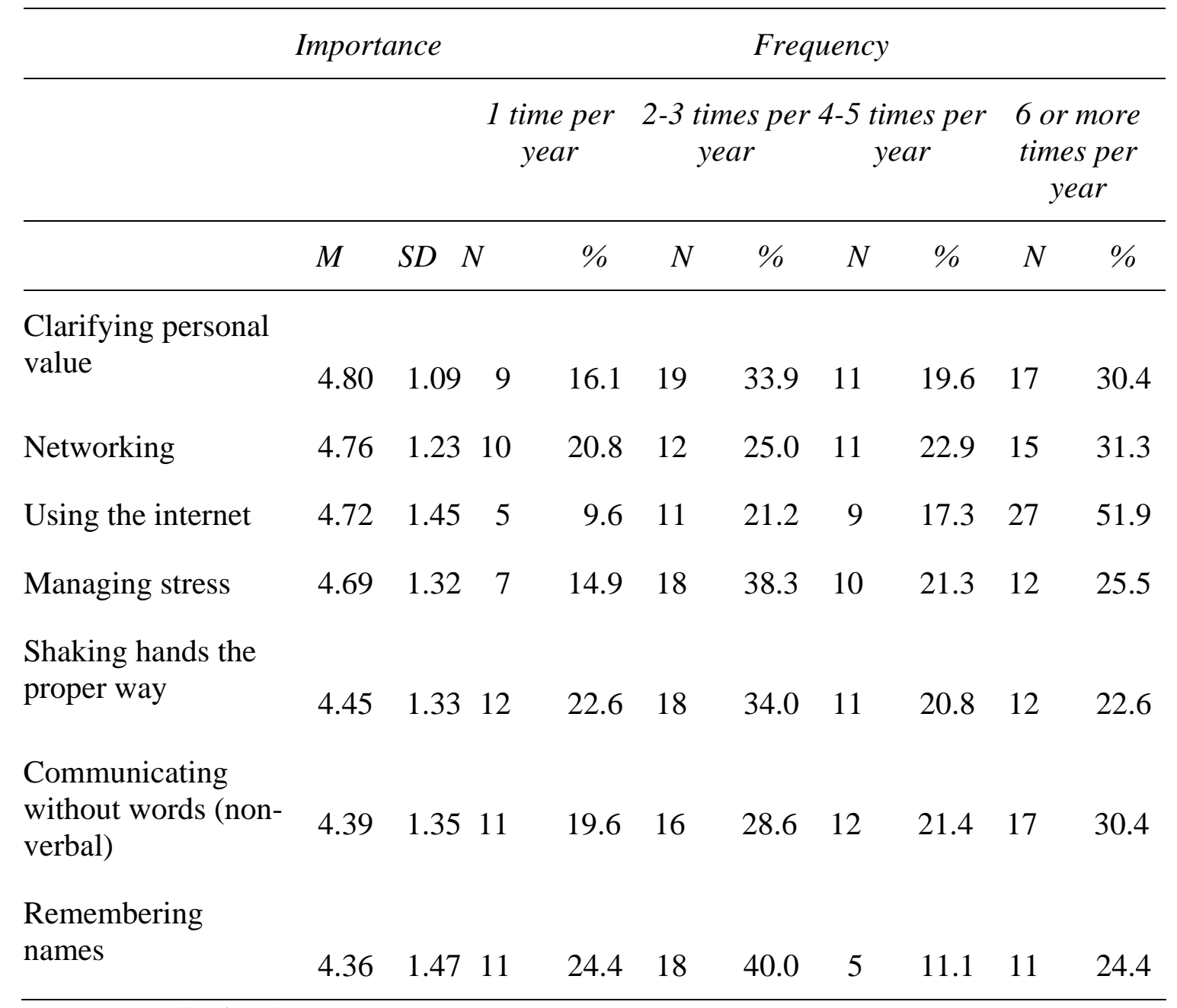

Importance Scale: 1 - Not Important 6 - Very Important

Respondents were asked where they taught the topic of being responsible. Fiftyseven respondents (91.9\%) taught being responsible in the classroom and 47 teachers (75.8\%) identified they taught being responsible at FFA meetings, 43 advisors (69.4\%) taught the topic in special training, 37 teachers (59.7\%) taught the topic one-on-one, and one respondent (1.6\%) did not teach the topic (see Table 14). 
Table 14

Location Personal Skills are Taught

\begin{tabular}{|c|c|c|c|c|}
\hline & \multicolumn{2}{|c|}{ Not Taught } & \multicolumn{2}{|c|}{ Taught } \\
\hline & $N$ & $\%$ & $N$ & $\%$ \\
\hline \multicolumn{5}{|l|}{ Effective listening } \\
\hline Classroom & 8 & 13.3 & 52 & 86.7 \\
\hline FFA Meeting & 32 & 53.3 & 28 & 46.7 \\
\hline Special Training & 37 & 61.7 & 23 & 38.3 \\
\hline One-on-one & 37 & 61.7 & 23 & 38.3 \\
\hline Not at all & 56 & 93.3 & 4 & 6.7 \\
\hline \multicolumn{5}{|c|}{$\begin{array}{l}\text { Communicating without words } \\
\text { (non-verbal) }\end{array}$} \\
\hline Classroom & 14 & 23.7 & 45 & 76.3 \\
\hline FFA Meeting & 39 & 66.1 & 20 & 33.9 \\
\hline Special Training & 37 & 62.7 & 22 & 37.3 \\
\hline One-on-one & 40 & 67.8 & 19 & 32.2 \\
\hline Not at all & 52 & 88.1 & 7 & 11.9 \\
\hline \multicolumn{5}{|c|}{ Clarifying personal value } \\
\hline Classroom & 10 & 16.9 & 49 & 83.1 \\
\hline FFA Meeting & 30 & 50.8 & 29 & 49.2 \\
\hline Special Training & 37 & 62.7 & 22 & 37.3 \\
\hline One-on-one & 35 & 59.3 & 24 & 40.7 \\
\hline Not at all & 56 & 94.9 & 3 & 5.1 \\
\hline
\end{tabular}


Table 14 (Continued)

Location Personal Skills are Taught

\begin{tabular}{|c|c|c|c|c|}
\hline & \multicolumn{2}{|c|}{ Not Taught } & \multicolumn{2}{|c|}{ Taught } \\
\hline & $N$ & $\%$ & $N$ & $\%$ \\
\hline \multicolumn{5}{|l|}{ Relationship building } \\
\hline Classroom & 16 & 26.2 & 45 & 73.8 \\
\hline FFA Meeting & 30 & 49.2 & 31 & 50.8 \\
\hline Special Training & 25 & 41.0 & 36 & 59.0 \\
\hline One-on-one & 32 & 52.5 & 29 & 47.5 \\
\hline Not at all & 56 & 91.8 & 5 & 8.2 \\
\hline \multicolumn{5}{|c|}{ Shaking hands the proper way } \\
\hline Classroom & 18 & 29.5 & 43 & 70.5 \\
\hline FFA Meeting & 38 & 62.3 & 23 & 37.7 \\
\hline Special Training & 37 & 60.7 & 24 & 39.3 \\
\hline One-on-one & 39 & 63.9 & 22 & 36.1 \\
\hline Not at all & 55 & 90.2 & 6 & 9.8 \\
\hline \multicolumn{5}{|l|}{ Remembering names } \\
\hline Classroom & 31 & 50.8 & 30 & 49.2 \\
\hline FFA Meeting & 45 & 73.8 & 16 & 26.2 \\
\hline Special Training & 41 & 67.2 & 20 & 32.8 \\
\hline One-on-one & 45 & 73.8 & 16 & 26.2 \\
\hline Not at all & 44 & 72.1 & 17 & 27.9 \\
\hline
\end{tabular}


Table 14 (Continued)

Location Personal Skills are Taught

\begin{tabular}{|c|c|c|c|c|}
\hline & \multicolumn{2}{|c|}{ Not Taught } & \multicolumn{2}{|c|}{ Taught } \\
\hline & $N$ & $\%$ & $N$ & $\%$ \\
\hline \multicolumn{5}{|l|}{ Managing stress } \\
\hline Classroom & 29 & 48.3 & 31 & 51.7 \\
\hline FFA Meeting & 46 & 76.7 & 14 & 23.3 \\
\hline Special Training & 40 & 66.7 & 20 & 33.3 \\
\hline One-on-one & 37 & 61.7 & 23 & 38.3 \\
\hline Not at all & 43 & 71.7 & 17 & 28.3 \\
\hline \multicolumn{5}{|c|}{ Accepting constructive criticism } \\
\hline Classroom & 19 & 31.1 & 42 & 68.9 \\
\hline FFA Meeting & 36 & 59.0 & 25 & 41.0 \\
\hline Special Training & 36 & 59.0 & 25 & 41.0 \\
\hline One-on-one & 27 & 44.3 & 34 & 55.7 \\
\hline Not at all & 56 & 91.8 & 5 & 8.2 \\
\hline \multicolumn{5}{|l|}{ Managing your life } \\
\hline Classroom & 16 & 27.1 & 43 & 72.9 \\
\hline FFA Meeting & 42 & 71.2 & 17 & 28.8 \\
\hline Special Training & 36 & 61.0 & 23 & 39.0 \\
\hline One-on-one & 32 & 54.2 & 27 & 45.8 \\
\hline Not at all & 50 & 84.7 & 9 & 15.3 \\
\hline
\end{tabular}


Table 14 (Continued)

Location Personal Skills are Taught

\begin{tabular}{|c|c|c|c|c|}
\hline & \multicolumn{2}{|c|}{ Not Taught } & \multicolumn{2}{|c|}{ Taught } \\
\hline & $N$ & $\%$ & $N$ & $\%$ \\
\hline \multicolumn{5}{|l|}{ Using the internet } \\
\hline Classroom & 7 & 11.7 & 53 & 88.3 \\
\hline FFA Meeting & 40 & 66.7 & 20 & 33.3 \\
\hline Special Training & 40 & 66.7 & 20 & 33.3 \\
\hline One-on-one & 32 & 53.3 & 28 & 46.7 \\
\hline Not at all & 54 & 90.0 & 6 & 10.0 \\
\hline \multicolumn{5}{|l|}{ Networking } \\
\hline Classroom & 22 & 37.9 & 36 & 62.1 \\
\hline FFA Meeting & 30 & 51.7 & 28 & 48.3 \\
\hline Special Training & 34 & 58.6 & 24 & 41.4 \\
\hline One-on-one & 32 & 55.2 & 26 & 44.8 \\
\hline Not at all & 47 & 81.0 & 11 & 19.0 \\
\hline \multicolumn{5}{|c|}{ Managing your time effectively } \\
\hline Classroom & 10 & 16.4 & 51 & 83.6 \\
\hline FFA Meeting & 31 & 50.8 & 30 & 49.2 \\
\hline Special Training & 27 & 44.3 & 34 & 55.7 \\
\hline One-on-one & 28 & 45.9 & 33 & 54.1 \\
\hline Not at all & 59 & 96.7 & 2 & 3.3 \\
\hline
\end{tabular}


Table 14 (Continued)

Location Personal Skills are Taught

\begin{tabular}{|c|c|c|c|c|}
\hline & \multicolumn{2}{|c|}{ Not Taught } & \multicolumn{2}{|c|}{ Taught } \\
\hline & $N$ & $\%$ & $N$ & $\%$ \\
\hline \multicolumn{5}{|l|}{ Being responsible } \\
\hline Classroom & 5 & 8.1 & 57 & 91.9 \\
\hline FFA Meeting & 15 & 24.2 & 47 & 75.8 \\
\hline Special Training & 19 & 30.6 & 43 & 69.4 \\
\hline One-on-one & 25 & 40.3 & 37 & 59.7 \\
\hline Not at all & 61 & 98.4 & 1 & 1.6 \\
\hline \multicolumn{5}{|c|}{ Improving self confidence } \\
\hline Classroom & 9 & 15.0 & 51 & 85.0 \\
\hline FFA Meeting & 25 & 41.7 & 35 & 58.3 \\
\hline Special Training & 30 & 50.0 & 30 & 50.0 \\
\hline One-on-one & 19 & 31.7 & 41 & 68.3 \\
\hline Not at all & 60 & 100.0 & & \\
\hline \multicolumn{5}{|c|}{ Creating a great first impression } \\
\hline Classroom & 11 & 18.6 & 48 & 81.4 \\
\hline FFA Meeting & 29 & 49.2 & 30 & 50.8 \\
\hline Special Training & 28 & 47.5 & 31 & 52.5 \\
\hline One-on-one & 28 & 47.5 & 31 & 52.5 \\
\hline Not at all & 57 & 96.6 & 2 & 3.4 \\
\hline
\end{tabular}


Table 14 (Continued)

Location Personal Skills are Taught

\begin{tabular}{lcccc}
\hline & \multicolumn{2}{c}{ Not Taught } & \multicolumn{2}{c}{ Taught } \\
\hline & $N$ & $\%$ & $N$ & $\%$ \\
\hline Keys to personal success & 8 & 13.8 & 50 & 86.2 \\
Classroom & 29 & 50.0 & 29 & 50.0 \\
FFA Meeting & 27 & 46.6 & 31 & 53.4 \\
Special Training & 29 & 50.0 & 29 & 50.0 \\
One-on-one & 55 & 94.8 & 3 & 5.2 \\
Not at all & & & & \\
\hline
\end{tabular}

Effective listening. Respondents were asked the frequency they taught the skill and the importance they place on teaching the skill to their students. Using a scale of 1-6 with 1 being “not important” and 6 "very important” the average rating of the importance of teaching effective listening was $5.34(\mathrm{SD}=.88$ ) (see Table 13). Four respondents (6.9\%) taught effective listening once a year. The skill was taught 2-3 times per year by 13 respondents (22.4\%), 4-5 times per year by 10 (17.2\%), and 6 or more times per year by 31 advisors (53.4\%) (see Table 13$)$.

FFA advisors were asked where they taught the skill of effective listening. Fiftytwo respondents (86.7\%) taught effective listening in the classroom and 28 teachers (46.7\%) identified they taught effective listening at FFA meetings, 23 advisors (38.3\%) taught the skill both in special training and one-on-one, and four respondents (6.7\%) did not teach the skill (see Table 14). 
Improving self confidence. Agricultural science teachers were asked the frequency they taught the skill and the importance they place on teaching the skill to their students. Using a scale of 1-6 with 1 being "not important" and 6 "very important" the average rating of the importance of teaching improving self confidence was 5.09 (SD =.94) (see Table 13). Seven respondents (12.3\%) taught improving self confidence once a year. The skill was taught 2-3 times per year by 20 respondents (35.1\%), $4-5$ times per year by six (10.5\%), and 6 or more times per year by 24 advisors (42.1\%) (see Table 13).

FFA advisors were asked where they taught the skill of improving self confidence. Fifty-one respondents (85\%) taught improving self confidence in the classroom and 35 teachers (58.3\%) identified they taught improving self confidence at FFA meetings, 30 advisors (50\%) taught the skill in special training, 41 respondents (68.3\%) taught the skill one-on-one, and none of the respondents (0\%) did not teach the skill (see Table 14).

Managing your time effectively. Respondents were asked the frequency they taught the skill and the importance they place on teaching the skill to their students. Using a scale of 1-6 with 1 being "not important" and 6 "very important" the average rating of the importance of teaching managing your time effectively was 5.08 ( $\mathrm{SD}=.96$ ) (see Table 13). Ten respondents (17.2\%) taught managing your time effectively once a year. The skill was taught 2-3 times per year by 17 respondents (29.3\%), 4-5 times per year by nine (15.5\%), and 6 or more times per year by 22 advisors (37.9\%) (see Table 13).

Agricultural science teachers were asked where they taught the skill of managing your time effectively. Fifty-one respondents (83.6\%) taught managing your time 
effectively in the classroom and 30 teachers (49.2\%) identified they taught managing your time effectively at FFA meetings, 34 advisors (55.7\%) taught the skill in special training, 33 respondents (54.1\%) taught the skill one-on-one, and two respondents (3.3\%) did not teach the skill (see Table 14).

Creating a great first impression. FFA advisors were asked the frequency they taught the skill and the importance they place on teaching the skill to their students. Using a scale of 1-6 with 1 being "not important" and 6 "very important" the average rating of the importance of teaching creating a great first impression was $5.04(\mathrm{SD}=.96)$ (see Table 13). Nine respondents (17\%) taught creating a great first impression once a year. The skill was taught 2-3 times per year by 13 respondents (24.5\%), 4-5 times per year by 15 (28.3\%), and 6 or more times per year by 16 advisors (30.2\%) (see Table 13).

Agricultural science teachers were asked where they taught the skill of creating a great first impression. Forty-eight respondents (81.4\%) taught creating a great first impression in the classroom and 30 teachers (50.8\%) identified they taught creating a great first impression at FFA meetings, 31 advisors (52.5\%) taught the skill in both special training and one-on-one, and two respondents (3.4\%) did not teach the skill (see Table 14).

Relationship building. Respondents were asked the frequency they taught the skill and the importance they place on teaching the skill to their students. Using a scale of 1-6 with 1 being "not important" and 6 "very important" the average rating of the importance of teaching relationship building was $5.03(\mathrm{SD}=1.03)$ (see Table 13). Four respondents (7.3\%) taught relationship building once a year. The skill was taught 2-3 times per year 
by 24 respondents (43.6\%), 4-5 times per year by eight (14.5\%), and 6 or more times per year by 29 advisors (34.5\%) (see Table 13).

FFA advisors were asked where they taught the skill of relationship building. Forty-five respondents (73.8\%) taught relationship building in the classroom and 31 teachers (50.8\%) identified they taught relationship building at FFA meetings, 36 advisors (59\%) taught the skill in special training, 39 respondents (47.5\%) taught the skill one-on-one, and five respondents (8.2\%) did not teach the skill (see Table 14).

Managing your life. FFA advisors were asked the frequency they taught the skill and the importance they place on teaching the skill to their students. Using a scale of 1-6 with 1 being "not important” and 6 "very important” the average rating of the importance of teaching managing your life was $4.94(\mathrm{SD}=1.16)$ (see Table 13). Eight respondents (15.1\%) taught managing your life once a year. The skill was taught 2-3 times per year by 14 respondents (26.4\%), 4-5 times per year by 10 (18.9\%), and 6 or more times per year by 21 advisors (39.6\%) (see Table 13).

Agricultural education instructors were asked where they taught the skill of managing your life. Forty-three respondents (72.9\%) taught managing your life in the classroom and 17 teachers (28.8\%) identified they taught managing your life at FFA meetings, 23 advisors (39\%) taught the skill in special training, 27 respondents (45.8\%) taught the skill one-on-one, and nine respondents (15.3\%) did not teach the skill (see Table 14).

Accepting constructive criticism. Respondents were asked the frequency they taught the skill and the importance they place on teaching the skill to their students. Using a scale of 1-6 with 1 being "not important” and 6 "very important” the average 
rating of the importance of teaching accepting constructive criticism was 4.90 (SD =1.09) (see Table 13). Nine respondents (16.4\%) taught accepting constructive criticism once a year. The skill was taught 2-3 times per year by 19 respondents (34.5\%), 4-5 times per year by 14 (25.5\%), and 6 or more times per year by 13 advisors (23.6\%) (see Table 13).

Agricultural education instructors were asked where they taught the skill of accepting constructive criticism. Forty-two respondents (68.9\%) taught accepting constructive criticism in the classroom and 25 teachers (41\%) identified they taught accepting constructive criticism at both FFA meetings and in special training, 34 respondents (55.7\%) taught the skill one-on-one, and five respondents (8.2\%) did not teach the skill (see Table 14).

Keys to personal success. FFA advisors were asked the frequency they taught the topic and the importance they place on teaching the topic to their students. Using a scale of 1-6 with 1 being “not important” and 6 "very important” the average rating of the importance of teaching keys to personal success was 4.88 (SD =1.14) (see Table 13). Eight respondents (14\%) taught keys to personal success once a year. The topic was taught 2-3 times per year by 22 respondents (38.6\%), 4-5 times per year by 10 (17.5\%), and 6 or more times per year by 17 advisors (29.8\%) (see Table 13).

Respondents were asked where they taught the topic of keys to personal success. Fifty respondents (86.2\%) taught keys to personal success in the classroom and 29 teachers (50\%) identified they taught keys to personal success at FFA meetings, 31 advisors (53.4\%) taught the topic in special training, 29 respondents (50\%) taught the topic one-on-one, and three respondents (5.2\%) did not teach the topic (see Table 14). 
Clarifying personal value. Agricultural science instructors were asked the frequency they taught the skill and the importance they place on teaching the skill to their students. Using a scale of 1-6 with 1 being "not important" and 6 "very important" the average rating of the importance of teaching clarifying personal value was 4.80 (SD $=1.09$ ) (see Table 13). Nine respondents (16.1\%) taught clarifying personal value once a year. The skill was taught 2-3 times per year by 19 respondents (33.9\%), 4-5 times per year by 11 (19.6\%), and 6 or more times per year by 17 advisors (30.4\%) (see Table 13). FFA advisors were asked where they taught the skill of clarifying personal value. Forty-nine respondents (83.1\%) taught clarifying personal value in the classroom and 29 teachers (49.2\%) identified they taught clarifying personal value at FFA meetings, 22 advisors (37.3\%) taught the skill in special training, 24 respondents (40.7\%) taught the skill one-on-one, and three respondents (5.1\%) did not teach the skill (see Table 14).

Networking. Respondents were asked the frequency they taught the skill and the importance they place on teaching the skill to their students. Using a scale of 1-6 with 1 being "not important" and 6 "very important" the average rating of the importance of teaching networking was $4.76(\mathrm{SD}=1.23)$ (see Table 13). Ten respondents $(20.8 \%)$ taught networking once a year. The skill was taught 2-3 times per year by 12 respondents (25\%), $4-5$ times per year by 11 (22.9\%), and 6 or more times per year by 15 advisors (31.3\%) (see Table 13).

Agricultural science instructors were asked where they taught the skill of networking. Thirty-six respondents (62.1\%) taught networking in the classroom and 28 teachers (48.3\%) identified they taught networking at FFA meetings, 24 advisors (41.4\%) 
taught the skill in special training, 26 respondents (44.8\%) taught the skill one-on-one, and 11 respondents (19\%) did not teach the skill (see Table 14).

Using the internet. FFA advisors were asked the frequency they taught the skill and the importance they place on teaching the skill to their students. Using a scale of 1-6 with 1 being "not important" and 6 "very important” the average rating of the importance of teaching using the internet was $4.72(\mathrm{SD}=1.45)$ (see Table 13). Five respondents (9.6\%) taught using the internet once a year. The skill was taught 2-3 times per year by 11 respondents (21.2\%), $4-5$ times per year by nine (17.3\%), and 6 or more times per year by 27 advisors (51.9\%) (see Table 13).

Agricultural science instructors were asked where they taught the skill of using the internet. Fifty-three respondents (88.3\%) taught using the internet in the classroom and 20 teachers (33.3\%) identified they taught using the internet at both FFA meetings and in special training, 28 respondents (46.7\%) taught the skill one-on-one, and six respondents (10\%) did not teach the skill (see Table 14).

Managing stress. Respondents were asked the frequency they taught the skill and the importance they place on teaching the skill to their students. Using a scale of 1-6 with 1 being "not important" and 6 "very important" the average rating of the importance of teaching managing stress was 4.69 ( $\mathrm{SD}=1.32)$ (see Table 13). Seven respondents (14.9\%) taught managing stress once a year. The skill was taught 2-3 times per year by 18 respondents (38.3\%), $4-5$ times per year by 10 (21.3\%), and 6 or more times per year by 12 advisors (25.5\%) (see Table 13).

FFA advisors were asked where they taught the skill of managing stress. Thirtyone respondents (51.7\%) taught managing stress in the classroom and 14 teachers 
(23.3\%) identified they taught managing stress at FFA meetings, 20 advisors (33.3\%) taught the skill in special training, 23 respondents (38.3\%) taught the skill one-on-one, and 17 respondents (28.3\%) did not teach the skill (see Table 14 ).

Shaking hands the proper way. FFA advisors were asked the frequency they taught the skill and the importance they place on teaching the skill to their students. Using a scale of 1-6 with 1 being "not important" and 6 "very important" the average rating of the importance of teaching shaking hands the proper way was $4.45(\mathrm{SD}=1.33$ ) (see Table 13). Twelve respondents (22.6\%) taught shaking hands the proper way once a year. The skill was taught 2-3 times per year by 18 respondents (34\%), 4-5 times per year by 11 (20.8\%), and 6 or more times per year by 12 advisors (22.6\%) (see Table 13). Agricultural science teachers were asked where they taught the skill of shaking hands the proper way. Forty-three respondents (70.5\%) taught shaking hands the proper way in the classroom and 23 teachers (37.3\%) identified they taught shaking hands the proper way at FFA meetings, 24 advisors (39.3\%) taught the skill in special training, 22 respondents (36.1\%) taught the skill one-on-one, and six respondents (9.8\%) did not teach the skill (see Table 14).

Communicating without words (non verbal). Respondents were asked the frequency they taught the skill and the importance they place on teaching the skill to their students. Using a scale of 1-6 with 1 being "not important" and 6 "very important" the average rating of the importance of teaching communicating without words (non verbal) was 4.39 (SD =1.35) (see Table 13). Eleven respondents (19.6\%) taught communicating without words (non verbal) once a year. The skill was taught 2-3 times per year by 16 
respondents (28.6\%), 4-5 times per year by 12 (21.4\%), and 6 or more times per year by 17 advisors (30.4\%) (see Table 13).

Agricultural science instructors were asked where they taught the skill of communicating without words (non verbal). Forty-five respondents (76.3\%) taught communicating without words (non verbal) in the classroom and 20 teachers (33.9\%) identified they taught communicating without words (non verbal) at FFA meetings, 22 advisors (37.3\%) taught the skill in special training, 19 respondents (32.2\%) taught the skill one-on-one, and seven respondents (11.9\%) did not teach the skill (see Table 14).

Remembering names. FFA advisors were asked the frequency they taught the skill and the importance they place on teaching the skill to their students. Using a scale of 1-6 with 1 being “not important” and 6 "very important” the average rating of the importance of teaching remembering names was $4.36(\mathrm{SD}=1.47)$ (see Table 13). Eleven respondents (24.4\%) taught remembering names once a year. The skill was taught 2-3 times per year by 18 respondents (40\%), 4-5 times per year by five (11.1\%), and 6 or more times per year by 11 advisors (24.4\%) (see Table 13$)$.

Respondents were asked where they taught the skill of remembering names. Thirty respondents (49.2\%) taught remembering names in the classroom and 16 teachers (26.2\%) identified they taught remembering names at FFA meetings, 20 advisors (32.8\%) taught the skill in special training, 16 respondents (26.2\%) taught the skill one-on-one, and 17 respondents (27.9\%) did not teach the skill (see Table 14). Importance, Frequency, and Location of Instruction of Planning \& Teamwork Skills

Teamwork. Respondents were asked the frequency they taught the topic and the importance they place on teaching the topic to their students. Using a scale of 1-6 with 1 
being “not important” and 6 "very important” the average rating of the importance of teaching teamwork was $5.68(\mathrm{SD}=.54)$ (see Table 15$)$. One respondent $(1.7 \%)$ taught teamwork once a year. The topic was taught 2-3 times per year by 12 respondents (20.7\%), 4-5 times per year by nine (15.5\%), and 6 or more times per year by 36 advisors (62.1\%) (see Table 15).

Table 15

Importance \& Frequency of Planning \& Teamwork Skills

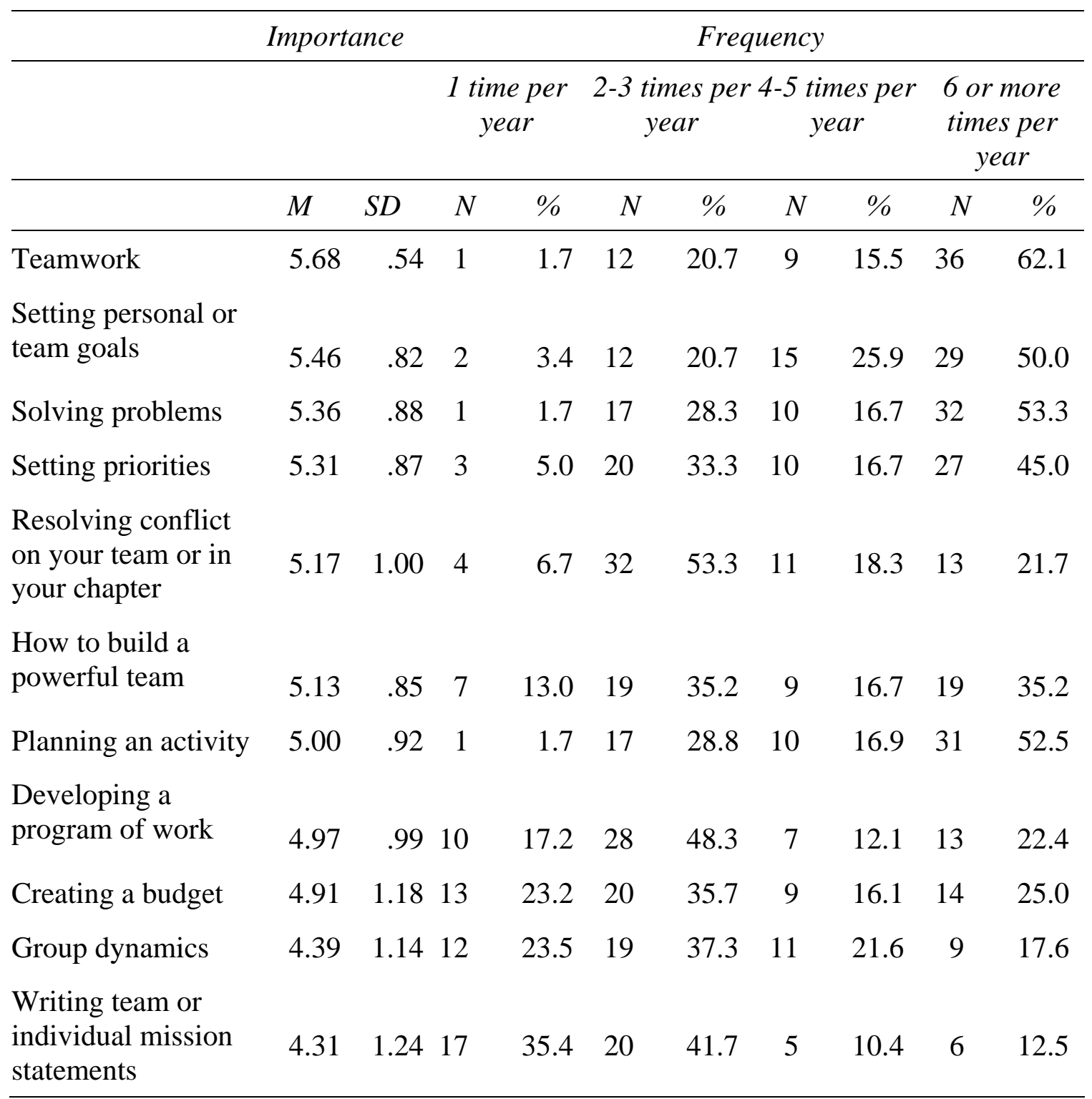

Importance Scale: 1 - Not Important 6 - Very Important 
Agricultural science teachers were asked where they taught the topic of teamwork. Fifty-six respondents (93.3\%) taught teamwork in the classroom and 52 teachers (85.2\%) identified they taught teamwork at FFA meetings, 44 advisors (73.3\%) taught the topic in special training, 42 respondents (68.9\%) taught the topic one-on-one, and one respondent (1.7\%) did not teach the topic (see Table 16).

Table 16

Location Planning \& Teamwork Skills are Taught

\begin{tabular}{lcccc}
\hline & \multicolumn{2}{c}{ Not Taught } & \multicolumn{2}{c}{ Taught } \\
\cline { 2 - 5 } & $N$ & $\%$ & $N$ & $\%$ \\
\hline $\begin{array}{l}\text { Resolving conflict on your team or } \\
\text { in your chapter }\end{array}$ & 32 & 52.5 & 29 & 47.5 \\
Classroom & 38 & 62.3 & 23 & 37.7 \\
FFA Meeting & 27 & 44.3 & 34 & 55.7 \\
Special Training & 27 & 44.3 & 34 & 55.7 \\
One-on-one & 59 & 96.7 & 2 & 3.3 \\
Not at all & & & & \\
Planning an activity & & & & \\
Classroom & 13 & 21.3 & 48 & 78.7 \\
FFA Meeting & 17 & 27.9 & 44 & 52.5 \\
Special Training & 29 & 47.5 & 32 & \\
One-on-one & & 47.5 & 32 & \\
Not at all & & & & \\
\hline
\end{tabular}


Table 16 (Continued)

Location Planning \& Teamwork Skills are Taught

\begin{tabular}{|c|c|c|c|c|}
\hline & \multicolumn{2}{|c|}{ Not Taught } & \multicolumn{2}{|c|}{ Taught } \\
\hline & $N$ & $\%$ & $N$ & $\%$ \\
\hline \multicolumn{5}{|l|}{ Setting priorities } \\
\hline Classroom & 8 & 13.1 & 53 & 86.9 \\
\hline FFA Meeting & 33 & 54.1 & 28 & 45.9 \\
\hline Special Training & 34 & 55.7 & 27 & 44.3 \\
\hline One-on-one & 33 & 54.1 & 28 & 45.9 \\
\hline Not at all & 60 & 98.4 & 1 & 1.6 \\
\hline \multicolumn{5}{|l|}{ Solving problems } \\
\hline Classroom & 8 & 13.1 & 53 & 86.9 \\
\hline FFA Meeting & 22 & 36.1 & 39 & 63.9 \\
\hline Special Training & 30 & 49.2 & 31 & 50.8 \\
\hline One-on-one & 26 & 42.6 & 35 & 57.4 \\
\hline Not at all & 60 & 98.4 & 1 & 1.6 \\
\hline \multicolumn{5}{|c|}{ Setting personal or team goals } \\
\hline Classroom & 11 & 18.3 & 49 & 81.7 \\
\hline FFA Meeting & 15 & 25.0 & 45 & 75.0 \\
\hline Special Training & 20 & 33.3 & 40 & 66.7 \\
\hline One-on-one & 25 & 41.7 & 35 & 58.3 \\
\hline Not at all & 59 & 98.3 & 1 & 1.7 \\
\hline
\end{tabular}


Table 16 (Continued)

Location Planning \& Teamwork Skills are Taught

\begin{tabular}{|c|c|c|c|c|}
\hline & \multicolumn{2}{|c|}{ Not Taught } & \multicolumn{2}{|c|}{ Taught } \\
\hline & $N$ & $\%$ & $N$ & $\%$ \\
\hline \multicolumn{5}{|c|}{ Developing a program of work } \\
\hline Classroom & 32 & 53.3 & 28 & 46.7 \\
\hline FFA Meeting & 22 & 36.7 & 38 & 63.3 \\
\hline Special Training & 21 & 35.0 & 39 & 65.0 \\
\hline One-on-one & 40 & 66.7 & 20 & 33.3 \\
\hline Not at all & 58 & 96.7 & 2 & 3.3 \\
\hline \multicolumn{5}{|l|}{ Creating a budget } \\
\hline Classroom & 21 & 34.4 & 40 & 65.6 \\
\hline FFA Meeting & 29 & 47.5 & 32 & 52.5 \\
\hline Special Training & 32 & 52.5 & 29 & 47.5 \\
\hline One-on-one & 34 & 55.7 & 27 & 44.3 \\
\hline Not at all & 57 & 93.4 & 4 & 6.6 \\
\hline \multicolumn{5}{|c|}{ How to build a powerful team } \\
\hline Classroom & 31 & 50.8 & 30 & 49.2 \\
\hline FFA Meeting & 24 & 39.3 & 37 & 60.7 \\
\hline Special Training & 24 & 39.3 & 37 & 60.7 \\
\hline One-on-one & 38 & 62.3 & 23 & 37.7 \\
\hline Not at all & 55 & 90.2 & 6 & 9.8 \\
\hline
\end{tabular}


Table 16 (Continued)

Location Planning \& Teamwork Skills are Taught

\begin{tabular}{|c|c|c|c|c|}
\hline & \multicolumn{2}{|c|}{ Not Taught } & \multicolumn{2}{|c|}{ Taught } \\
\hline & $N$ & $\%$ & $N$ & $\%$ \\
\hline \multicolumn{5}{|c|}{$\begin{array}{l}\text { Writing team or individual } \\
\text { mission statements }\end{array}$} \\
\hline Classroom & 39 & 65.0 & 21 & 35.0 \\
\hline FFA Meeting & 35 & 58.3 & 25 & 41.7 \\
\hline Special Training & 34 & 56.7 & 26 & 43.3 \\
\hline One-on-one & 44 & 73.3 & 16 & 26.7 \\
\hline Not at all & 49 & 81.7 & 11 & 18.3 \\
\hline \multicolumn{5}{|l|}{ Group dynamics } \\
\hline Classroom & 21 & 36.2 & 37 & 63.8 \\
\hline FFA Meeting & 30 & 51.7 & 28 & 48.3 \\
\hline Special Training & 29 & 50.0 & 29 & 50.0 \\
\hline One-on-one & 42 & 72.4 & 16 & 27.6 \\
\hline Not at all & 50 & 86.2 & 8 & 13.8 \\
\hline \multicolumn{5}{|l|}{ Teamwork } \\
\hline Classroom & 4 & 6.7 & 56 & 93.3 \\
\hline FFA Meeting & 9 & 14.8 & 52 & 85.2 \\
\hline Special Training & 16 & 26.7 & 44 & 73.3 \\
\hline One-on-one & 19 & 31.1 & 42 & 68.9 \\
\hline Not at all & 59 & 98.3 & 1 & 1.7 \\
\hline
\end{tabular}


Setting personal or team goals. FFA advisors were asked the frequency they taught the skill and the importance they place on teaching the skill to their students. Using a scale of 1-6 with 1 being "not important" and 6 "very important" the average rating of the importance of teaching setting personal or team goals was $5.46(\mathrm{SD}=.82)$ (see Table 15). Two respondents (3.4\%) taught setting personal or team goals once a year. The skill was taught 2-3 times per year by 12 respondents (20.7\%), 4-5 times per year by 15 (25.9\%), and 6 or more times per year by 29 advisors (50\%) (see Table 15).

Respondents were asked where they taught the skill of setting personal or team goals. Forty-nine respondents (81.7\%) taught setting personal or team goals in the classroom and 45 teachers (75\%) identified they taught setting personal or team goals at FFA meetings, 40 advisors (66.7\%) taught the skill in special training, 35 respondents (58.3\%) taught the skill one-on-one, and one respondent (1.7\%) did not teach the skill (see Table 16).

Solving problems. Agricultural science instructors were asked the frequency they taught the skill and the importance they place on teaching the skill to their students. Using a scale of 1-6 with 1 being "not important" and 6 "very important" the average rating of the importance of teaching solving problems was $5.36(\mathrm{SD}=.88$ ) (see Table 15). One respondent (1.7\%) taught solving problems once a year. The skill was taught 2-3 times per year by 17 respondents (28.3\%), 4-5 times per year by 10 (16.7\%), and 6 or more times per year by 32 advisors (53.3\%) (see Table 15).

FFA advisors were asked where they taught the skill of solving problems. Fiftythree respondents (86.9\%) taught solving problems in the classroom and 39 teachers (63.9\%) identified they taught solving problems at FFA meetings, 31 advisors (50.8\%) 
taught the skill in special training, 35 respondents (57.4\%) taught the skill one-on-one, and one respondent (1.6\%) did not teach the skill (see Table 16).

Setting priorities. Agricultural science instructors were asked the frequency they taught the skill and the importance they place on teaching the skill to their students. Using a scale of 1-6 with 1 being "not important" and 6 "very important" the average rating of the importance of teaching setting priorities was 5.31 (SD =.87) (see Table 15). Three respondents (5\%) taught setting priorities once a year. The skill was taught 2-3 times per year by 20 respondents (33.3\%), 4-5 times per year by 10 (16.7\%), and 6 or more times per year by 27 advisors (45\%) (see Table 15).

Respondents were asked where they taught the skill of setting priorities. Fiftythree respondents (86.9\%) taught setting priorities in the classroom and 28 teachers (45.9\%) identified they taught setting priorities at FFA meetings, 27 advisors (44.3\%) taught the skill in special training, 28 respondents (45.9\%) taught the skill one-on-one, and one respondent (1.6\%) did not teach the skill (see Table 16).

Resolving conflict on your team or in your chapter. FFA advisors were asked the frequency they taught the skill and the importance they place on teaching the skill to their students. Using a scale of 1-6 with 1 being "not important" and 6 "very important" the average rating of the importance of teaching resolving conflict on your team or in your chapter was $5.17(\mathrm{SD}=1.00)$ (see Table 15). Four respondents (6.7\%) taught resolving conflict on your team or in your chapter once a year. The skill was taught 2-3 times per year by 32 respondents (53.3\%), 4-5 times per year by 11 (18.3\%), and 6 or more times per year by 13 advisors (21.7\%) (see Table 15$)$. 
Agricultural science teachers were asked where they taught the skill of resolving conflict on your team or in your chapter. Twenty-nine respondents (47.5\%) taught resolving conflict on your team or in your chapter in the classroom and 23 teachers (37.7\%) identified they taught resolving conflict on your team or in your chapter at FFA meetings, 34 advisors (55.7\%) taught the skill in both special training and one-on-one, and two respondents (3.3\%) did not teach the skill (see Table 16).

How to build a powerful team. FFA advisors were asked the frequency they taught the topic and the importance they place on teaching the topic to their students. Using a scale of 1-6 with 1 being "not important" and 6 "very important" the average rating of the importance of teaching how to build a powerful team was 5.13 (SD =.85) (see Table 15). Seven respondents (13\%) taught how to build a powerful team once a year. The topic was taught 2-3 times per year by 19 respondents (35.2\%), 4-5 times per year by nine (16.7\%), and 6 or more times per year by 19 advisors (35.2\%) (see Table 15).

Respondents were asked where they taught the topic of how to build a powerful team. Thirty respondents (49.2\%) taught how to build a powerful team in the classroom and 37 teachers (60.7\%) identified they taught how to build a powerful team at both FFA meetings and in special training, 23 respondents (37.7\%) taught the topic one-on-one, and six respondents (9.8\%) did not teach the topic (see Table 16).

Planning an activity. FFA advisors were asked the frequency they taught the skill and the importance they place on teaching the skill to their students. Using a scale of 1-6 with 1 being "not important" and 6 "very important" the average rating of the importance of teaching planning an activity was $5.00(\mathrm{SD}=.92)$ (see Table 5). One respondent 
(1.7\%) taught planning an activity once a year. The skill was taught 2-3 times per year by 17 respondents (28.8\%), 4-5 times per year by 10 (16.9\%), and 6 or more times per year by 31 respondents (52.5\%) (see Table 5).

Respondents were asked where they taught the skill of planning an activity. Forty-eight teachers (78.7\%) taught planning an activity in the classroom and 44 teachers (72.1\%) identified they taught planning an activity at FFA meetings. Of the remaining teachers 32 (52.5\%) taught the skill at both special training and one-on-one, none of the respondents did not teach the skill (see Table 6).

Developing a program of work. Agricultural science instructors were asked the frequency they taught the skill and the importance they place on teaching the skill to their students. Using a scale of 1-6 with 1 being "not important" and 6 "very important" the average rating of the importance of teaching developing a program of work was 4.97 (SD =.99) (see Table 15). Ten respondents (17.2\%) taught developing a program of work once a year. The skill was taught 2-3 times per year by 28 respondents (48.3\%), 4-5 times per year by seven (12.1\%), and 6 or more times per year by 13 advisors (22.4\%) (see Table 15).

Respondents were asked where they taught the skill of developing a program of work. Twenty-eight respondents (46.7\%) taught developing a program of work in the classroom and 38 teachers (63.3\%) identified they taught developing a program of work at FFA meetings, 39 advisors (65\%) taught the skill in special training, 20 respondents (33.3\%) taught the skill one-on-one, and two respondents (3.3\%) did not teach the skill (see Table 16). 
Creating a budget. Agricultural science instructors were asked the frequency they taught the skill and the importance they place on teaching the skill to their students. Using a scale of 1-6 with 1 being "not important" and 6 "very important" the average rating of the importance of teaching developing a program of work was $4.91(\mathrm{SD}=1.18)$ (see Table 15). Thirteen respondents (23.2\%) taught developing a program of work once a year. The skill was taught 2-3 times per year by 20 respondents (35.7\%), $4-5$ times per year by nine (16.1\%), and 6 or more times per year by 14 advisors (25.0\%) (see Table 15).

Respondents were asked where they taught the skill of creating a budget. Forty respondents (65.6\%) taught creating a budget in the classroom and 32 teachers (52.5\%) identified they taught creating a budget at FFA meetings, 29 advisors (47.5\%) taught the skill in special training, 27 respondents (44.3\%) taught the skill one-on-one, and four respondents (6.6\%) did not teach the skill (see Table 16).

Group dynamics. FFA advisors were asked the frequency they taught the topic and the importance they place on teaching the topic to their students. Using a scale of 1-6 with 1 being "not important" and 6 "very important" the average rating of the importance of teaching group dynamics was 4.39 ( $\mathrm{SD}=1.14$ ) (see Table 15). Twelve respondents (23.5\%) taught group dynamics once a year. The topic was taught 2-3 times per year by 19 respondents (37.3\%), $4-5$ times per year by 11 (21.6\%), and 6 or more times per year by nine advisors (17.6\%) (see Table 15).

Agricultural science teachers were asked where they taught the topic of group dynamics. Thirty-seven respondents (63.8\%) taught group dynamics in the classroom and 28 teachers (48.3\%) identified they taught group dynamics at FFA meetings, 29 advisors 
(50\%) taught the topic in special training, 16 respondents (27.6\%) taught the topic oneon-one, and eight respondents (13.8\%) did not teach the topic (see Table 16).

Writing team or individual mission statements. FFA advisors were asked the frequency they taught the skill and the importance they place on teaching the skill to their students. Using a scale of 1-6 with 1 being "not important" and 6 "very important" the average rating of the importance of teaching writing team or individual mission statements was 4.31 ( $\mathrm{SD}=1.24)$ (see Table 15). Seventeen respondents (35.4\%) taught writing team or individual mission statements once a year. The skill was taught 2-3 times per year by 20 respondents (41.7\%), 4-5 times per year by five (10.4\%), and 6 or more times per year by six advisors (12.5\%) (see Table 15).

Respondents were asked where they taught the skill of writing team or individual mission statements. Twenty-one respondents (35\%) taught writing team or individual mission statements in the classroom and 25 teachers (41.7\%) identified they taught writing team or individual mission statements at FFA meetings, 26 advisors (43.3\%) taught the skill in special training, 16 respondents (26.7\%) taught the skill one-on-one, and 11 respondents (18.3\%) did not teach the skill (see Table 16). Importance, Frequency, and Location of Instruction of Leadership Qualities

Commitment. FFA advisors were asked the frequency they taught the skill and the importance they place on teaching the skill to their students. Using a scale of 1-6 with 1 being "not important" and 6 "very important" the average rating of the importance of teaching commitment was $5.45(\mathrm{SD}=.82)$ (see Table 17). Three respondents $(5.3 \%)$ taught commitment once a year. The skill was taught 2-3 times per year by 12 
respondents (21.1\%), 4-5 times per year by 15 (26.3\%), and 6 or more times per year by 27 advisors (47.4\%) (see Table 17).

Table 17

Importance \& Frequency of Leadership Qualities Skills

\begin{tabular}{|c|c|c|c|c|c|c|c|c|c|c|}
\hline & \multicolumn{4}{|c|}{ Importance } & \multicolumn{4}{|c|}{ Frequency } & & \\
\hline & \multirow[b]{2}{*}{$M$} & \multirow[b]{2}{*}{$S D$} & \multicolumn{2}{|c|}{$\begin{array}{c}1 \text { time per } \\
\text { year }\end{array}$} & \multicolumn{2}{|c|}{$\begin{array}{c}\text { 2-3 times per } \\
\text { year }\end{array}$} & \multicolumn{2}{|c|}{$\begin{array}{c}\text { 4-5 times per } \\
\text { year }\end{array}$} & \multicolumn{2}{|c|}{$\begin{array}{c}6 \text { or more } \\
\text { times per year }\end{array}$} \\
\hline & & & $N$ & $\%$ & $N$ & $\%$ & $N$ & $\%$ & $N$ & $\%$ \\
\hline Commitment & 5.45 & .82 & 3 & 5.3 & 12 & 21.1 & 15 & 26.3 & 27 & 47.4 \\
\hline Cooperation & 5.41 & .87 & 4 & 7.1 & 13 & 23.2 & 14 & 25.0 & 25 & 44.6 \\
\hline Ethical leadership & 5.37 & .92 & 6 & 10.7 & 16 & 28.6 & 7 & 12.5 & 27 & 48.2 \\
\hline $\begin{array}{l}\text { Maintaining a } \\
\text { positive attitude }\end{array}$ & 5.34 & .86 & 2 & 3.4 & 14 & 23.7 & 17 & 28.8 & 26 & $44.1 \%$ \\
\hline Integrity & 5.31 & .99 & 6 & 10.5 & 16 & 28.1 & 7 & 12.3 & 28 & 49.1 \\
\hline $\begin{array}{l}\text { Acceptance of } \\
\text { others }\end{array}$ & 5.28 & .91 & 4 & 7.0 & 17 & 29.8 & 12 & 21.1 & 24 & 42.1 \\
\hline Lifelong learning & 5.12 & 1.11 & 6 & 10.9 & 16 & 29.1 & 9 & 16.4 & 24 & 43.6 \\
\hline Gratitude & 5.11 & 1.16 & 5 & 9.4 & 16 & 30.2 & 10 & 18.9 & 22 & 41.5 \\
\hline Flexibility & 5.09 & .95 & 6 & 10.9 & 16 & 29.1 & 14 & 25.5 & 19 & 34.5 \\
\hline Passion & 5.04 & 1.18 & 5 & 10.0 & 17 & 34.0 & 9 & 18.0 & 19 & 38.0 \\
\hline Wisdom & 5.02 & 1.11 & 4 & 7.7 & 19 & 36.5 & 11 & 21.2 & 18 & 34.6 \\
\hline Forgiveness & 4.95 & .99 & 8 & 15.4 & 18 & 34.6 & 10 & 19.2 & 16 & 30.8 \\
\hline Risk-taking & 4.80 & 1.17 & 7 & 13.2 & 21 & 39.6 & 8 & 15.1 & 17 & 32.1 \\
\hline Humility & 4.79 & 1.19 & 6 & 11.8 & 17 & 33.3 & 14 & 27.5 & 14 & 27.5 \\
\hline
\end{tabular}

Importance Scale: 1 - Not Important 6 - Very Important 
Respondents were asked where they taught the skill of commitment. Forty-nine respondents (81.7\%) taught commitment in the classroom and 41 teachers $(67.2 \%)$ identified they taught commitment at FFA meetings, 40 advisors (66.7\%) taught the skill in both special training and one-on-one, and one respondent (1.7\%) did not teach the skill (see Table 18)

Table 18

Location Leadership Qualities are Taught

\begin{tabular}{lcccc}
\hline & \multicolumn{2}{c}{ Not Taught } & \multicolumn{2}{c}{ Taught } \\
\cline { 2 - 5 } & $N$ & $\%$ & $N$ & $\%$ \\
\hline Maintaining a positive attitude & & & & \\
Classroom & 4 & 6.7 & 56 & 93.3 \\
FFA Meeting & 20 & 32.8 & 41 & 67.2 \\
Special Training & 21 & 35.0 & 39 & 65.0 \\
One-on-one & 19 & 31.7 & 41 & 68.3 \\
Not at all & 59 & 98.3 & 1 & 1.7 \\
Humility & & & & \\
Classroom & 17 & 28.3 & 43 & 71.7 \\
FFA Meeting & 36 & 59.0 & 25 & 41.0 \\
Special Training & 36 & 60.0 & 24 & 40.0 \\
One-on-one & 26 & 43.3 & 34 & 56.7 \\
Not at all & 51 & 85.0 & 9 & 15.0 \\
\hline
\end{tabular}


Table 18 (Continued)

Location Leadership Qualities are Taught

\begin{tabular}{|c|c|c|c|c|}
\hline & \multicolumn{2}{|c|}{ Not Taught } & \multicolumn{2}{|c|}{ Taught } \\
\hline & $N$ & $\%$ & $N$ & $\%$ \\
\hline \multicolumn{5}{|l|}{ Cooperation } \\
\hline Classroom & 4 & 6.7 & 56 & 93.3 \\
\hline FFA Meeting & 17 & 27.9 & 44 & 72.1 \\
\hline Special Training & 21 & 35.0 & 39 & 65.0 \\
\hline One-on-one & 22 & 36.7 & 38 & 63.3 \\
\hline Not at all & 58 & 96.7 & 2 & 3.3 \\
\hline \multicolumn{5}{|l|}{ Flexibility } \\
\hline Classroom & 12 & 20.3 & 47 & 79.7 \\
\hline FFA Meeting & 24 & 40.0 & 36 & 60.0 \\
\hline Special Training & 28 & 47.5 & 31 & 52.5 \\
\hline One-on-one & 23 & 39.0 & 36 & 61.0 \\
\hline Not at all & 56 & 94.9 & 3 & 5.1 \\
\hline \multicolumn{5}{|l|}{ Commitment } \\
\hline Classroom & 11 & 18.3 & 49 & 81.7 \\
\hline FFA Meeting & 20 & 32.8 & 41 & 67.2 \\
\hline Special Training & 20 & 33.3 & 40 & 66.7 \\
\hline One-on-one & 20 & 33.3 & 40 & 66.7 \\
\hline Not at all & 59 & 98.3 & 1 & 1.7 \\
\hline
\end{tabular}


Table 18 (Continued)

Location Leadership Qualities are Taught

\begin{tabular}{|c|c|c|c|c|}
\hline & \multicolumn{2}{|c|}{ Not Taught } & \multicolumn{2}{|c|}{ Taught } \\
\hline & $N$ & $\%$ & $N$ & $\%$ \\
\hline \multicolumn{5}{|l|}{ Integrity } \\
\hline Classroom & 7 & 11.7 & 53 & 88.3 \\
\hline FFA Meeting & 25 & 41.7 & 35 & 58.3 \\
\hline Special Training & 27 & 45.0 & 33 & 55.0 \\
\hline One-on-one & 24 & 40.0 & 36 & 60.0 \\
\hline Not at all & 57 & 93.4 & 4 & 6.6 \\
\hline \multicolumn{5}{|l|}{ Risk-taking } \\
\hline Classroom & 11 & 18.3 & 49 & 81.7 \\
\hline FFA Meeting & 33 & 55.0 & 27 & 45.0 \\
\hline Special Training & 33 & 55.0 & 27 & 45.0 \\
\hline One-on-one & 32 & 53.3 & 28 & 46.7 \\
\hline Not at all & 52 & 85.2 & 9 & 14.8 \\
\hline \multicolumn{5}{|l|}{ Passion } \\
\hline Classroom & 22 & 36.7 & 38 & 63.3 \\
\hline FFA Meeting & 30 & 50.0 & 30 & 50.0 \\
\hline Special Training & 32 & 53.3 & 28 & 46.7 \\
\hline One-on-one & 24 & 40.0 & 36 & 60.0 \\
\hline Not at all & 50 & 82.0 & 11 & 18.0 \\
\hline
\end{tabular}


Table 18 (Continued)

Location Leadership Qualities are Taught

\begin{tabular}{|c|c|c|c|c|}
\hline & \multicolumn{2}{|c|}{ Not Taught } & \multicolumn{2}{|c|}{ Taught } \\
\hline & $N$ & $\%$ & $N$ & $\%$ \\
\hline \multicolumn{5}{|l|}{ Lifelong learning } \\
\hline Classroom & 9 & 15.3 & 50 & 84.7 \\
\hline FFA Meeting & 27 & 45.8 & 32 & 54.2 \\
\hline Special Training & 32 & 54.2 & 27 & 45.8 \\
\hline One-on-one & 26 & 44.1 & 33 & 55.9 \\
\hline Not at all & 54 & 90.0 & 6 & 10.0 \\
\hline \multicolumn{5}{|l|}{ Wisdom } \\
\hline Classroom & 14 & 23.7 & 45 & 76.3 \\
\hline FFA Meeting & 29 & 49.2 & 30 & 50.8 \\
\hline Special Training & 34 & 57.6 & 25 & 42.4 \\
\hline One-on-one & 25 & 42.4 & 34 & 57.6 \\
\hline Not at all & 52 & 86.7 & 8 & 13.3 \\
\hline \multicolumn{5}{|l|}{ Ethical leadership } \\
\hline Classroom & 13 & 21.7 & 47 & 78.3 \\
\hline FFA Meeting & 22 & 36.7 & 38 & 63.3 \\
\hline Special Training & 26 & 43.3 & 34 & 56.7 \\
\hline One-on-one & 22 & 36.7 & 38 & 63.3 \\
\hline Not at all & 56 & 91.8 & 5 & 8.2 \\
\hline
\end{tabular}


Table 18 (Continued)

Location Leadership Qualities are Taught

\begin{tabular}{|c|c|c|c|c|}
\hline & \multicolumn{2}{|c|}{ Not Taught } & \multicolumn{2}{|c|}{ Taught } \\
\hline & $N$ & $\%$ & $N$ & $\%$ \\
\hline \multicolumn{5}{|l|}{ Forgiveness } \\
\hline Classroom & 20 & 33.3 & 40 & 66.7 \\
\hline FFA Meeting & 32 & 53.3 & 28 & 46.7 \\
\hline Special Training & 36 & 60.0 & 24 & 40.0 \\
\hline One-on-one & 23 & 38.3 & 37 & 61.7 \\
\hline Not at all & 53 & 86.9 & 8 & 13.1 \\
\hline \multicolumn{5}{|l|}{ Gratitude } \\
\hline Classroom & 17 & 28.3 & 43 & 71.7 \\
\hline FFA Meeting & 25 & 41.7 & 35 & 58.3 \\
\hline Special Training & 27 & 45.0 & 33 & 55.0 \\
\hline One-on-one & 22 & 36.7 & 38 & 63.3 \\
\hline Not at all & 52 & 85.2 & 9 & 14.8 \\
\hline \multicolumn{5}{|l|}{ Acceptance of others } \\
\hline Classroom & 9 & 15.0 & 51 & 85.0 \\
\hline FFA Meeting & 23 & 38.3 & 37 & 61.7 \\
\hline Special Training & 27 & 45.0 & 33 & 55.0 \\
\hline One-on-one & 25 & 41.7 & 35 & 58.3 \\
\hline Not at all & 58 & 96.7 & 2 & 3.3 \\
\hline
\end{tabular}

Teaching cooperation. Agricultural science teachers were asked the frequency they taught the skill and the importance they place on teaching the skill to their students. 
Using a scale of 1-6 with 1 being "not important" and 6 "very important" the average rating of the importance of teaching cooperation was 5.41 ( $\mathrm{SD}=.87$ ) (see Table 17). Four respondents (7.1\%) taught cooperation once a year. The skill was taught 2-3 times per year by 13 respondents (23.2\%), 4-5 times per year by 14 (25\%), and 6 or more times per year by 25 advisors (44.6\%) (see Table 17).

Respondents were asked where they taught the skill of cooperation. Fifty-six respondents (93.3\%) taught cooperation in the classroom and 44 teachers (72.1\%) identified they taught cooperation at FFA meetings, 39 advisors (65\%) taught the skill in special training, 38 respondents (63.3\%) taught the skill one-on-one, and two respondents (3.3\%) did not teach the skill (see Table 18).

Ethical leadership. FFA advisors were asked the frequency they taught the topic and the importance they place on teaching the topic to their students. Using a scale of 1-6 with 1 being "not important" and 6 "very important" the average rating of the importance of teaching ethical leadership was $5.37(\mathrm{SD}=.92)$ (see Table 17). Six respondents (10.7\%) taught ethical leadership once a year. The topic was taught 2-3 times per year by 16 respondents (28.6\%), 4-5 times per year by seven (12.5\%), and 6 or more times per year by 27 advisors (48.2\%) (see Table 17).

Agricultural science instructors were asked where they taught the topic of ethical leadership. Forty-seven respondents (78.3\%) taught ethical leadership in the classroom and 38 teachers (63.3\%) identified they taught ethical leadership at FFA meetings, 34 advisors (56.7\%) taught the topic in special training, 38 respondents (63.3\%) taught the topic one-on-one, and five respondents (8.2\%) did not teach the topic (see Table 18). 
Maintaining a positive attitude. Respondents were asked the frequency they taught the skill and the importance they place on teaching the skill to their students. Using a scale of 1-6 with 1 being "not important" and 6 "very important" the average rating of the importance of teaching maintaining a positive attitude was $5.34(\mathrm{SD}=.86)$ (see Table 17). Two respondents (3.4\%) taught maintaining a positive attitude once a year. The skill was taught 2-3 times per year by 14 respondents (23.7\%), 4-5 times per year by 17 (28.8\%), and 6 or more times per year by 26 advisors (44.1\%) (see Table 17). FFA advisors were asked where they taught the skill of maintaining a positive attitude. Fifty-six respondents (93.3\%) taught maintaining a positive attitude in the classroom and 41 teachers (67.2\%) identified they taught maintaining a positive attitude at FFA meetings, 39 advisors (65\%) taught the skill in special training, 41 respondents (68.3\%) taught the skill one-on-one, and one respondent (1.7\%) did not teach the skill (see Table 18).

Integrity. Respondents were asked the frequency they taught the topic and the importance they place on teaching the topic to their students. Using a scale of 1-6 with 1 being "not important" and 6 "very important" the average rating of the importance of teaching integrity was 5.31 (SD =.99) (see Table 17). Six respondents (10.5\%) taught integrity once a year. The topic was taught 2-3 times per year by 16 respondents (28.1\%), 4-5 times per year by seven (12.3\%), and 6 or more times per year by 28 advisors (49.1\%) (see Table 17).

Agricultural science teachers were asked where they taught the topic of integrity. Fifty-three respondents (88.3\%) taught integrity in the classroom and 35 teachers (58.3\%) identified they taught integrity at FFA meetings, 33 advisors (55\%) taught the topic in 
special training, 36 respondents (60\%) taught the topic one-on-one, and four respondents (6.6\%) did not teach the topic (see Table 18).

Acceptance of others. Agricultural science teachers were asked the frequency they taught the topic and the importance they place on teaching the topic to their students. Using a scale of 1-6 with 1 being "not important" and 6 "very important" the average rating of the importance of teaching acceptance of others was 5.28 (SD =.91) (see Table 17). Four respondents (7\%) taught acceptance of others once a year. The topic was taught 2-3 times per year by 17 respondents (29.8\%), 4-5 times per year by 12 (21.1\%), and 6 or more times per year by 24 advisors (42.1\%) (see Table 17).

FFA advisors were asked where they taught the topic of acceptance of others. Fifty-one respondents (85\%) taught acceptance of others in the classroom and 37 teachers (61.7\%) identified they taught acceptance of others at FFA meetings, 33 advisors (55\%) taught the topic in special training, 35 respondents (68.3\%) taught the topic one-on-one, and two respondents (3.3\%) did not teach the topic (see Table 18).

Lifelong learning. Agricultural science teachers were asked the frequency they taught the topic and the importance they place on teaching the topic to their students. Using a scale of 1-6 with 1 being "not important" and 6 "very important" the average rating of the importance of teaching lifelong learning was $5.12(\mathrm{SD}=1.11)$ (see Table 17). Six respondents (10.9\%) taught lifelong learning once a year. The topic was taught 2-3 times per year by 16 respondents (29.1\%), $4-5$ times per year by nine (16.4\%), and 6 or more times per year by 24 advisors (43.6\%) (see Table 17 ).

Respondents were asked where they taught the topic of lifelong learning. Fifty respondents (84.7\%) taught lifelong learning in the classroom and 32 teachers (54.2\%) 
identified they taught lifelong learning at FFA meetings, 27 advisors (45.8\%) taught the topic in special training, 33 respondents (55.9\%) taught the topic one-on-one, and six respondents (10\%) did not teach the topic (see Table 18).

Gratitude. FFA advisors were asked the frequency they taught the topic and the importance they place on teaching the topic to their students. Using a scale of 1-6 with 1 being "not important" and 6 "very important" the average rating of the importance of teaching gratitude was 5.11 ( $\mathrm{SD}=1.16)$ (see Table 17). Five respondents (9.4\%) taught gratitude once a year. The topic was taught 2-3 times per year by 16 respondents (30.2\%), $4-5$ times per year by 10 (18.9\%), and 6 or more times per year by 22 advisors (41.5\%) (see Table 17).

Agricultural science teachers were asked where they taught the topic of gratitude. Forty-three respondents (71.7\%) taught gratitude in the classroom and 35 teachers (58.3\%) identified they taught gratitude at FFA meetings, 33 advisors (55\%) taught the topic in special training, 38 respondents (63.3\%) taught the topic one-on-one, and nine respondents (14.8\%) did not teach the topic (see Table 18).

Flexibility. FFA advisors were asked the frequency they taught the topic and the importance they place on teaching the topic to their students. Using a scale of 1-6 with 1 being "not important" and 6 "very important" the average rating of the importance of teaching flexibility was 5.09 (SD =.95) (see Table 17). Six respondents (10.9\%) taught flexibility once a year. The topic was taught 2-3 times per year by 16 respondents (29.1\%), 4-5 times per year by 14 (25.5\%), and 6 or more times per year by 19 advisors (34.5\%) (see Table 17). 
Respondents were asked where they taught the topic of flexibility. Forty-seven respondents (79.7\%) taught flexibility in the classroom and 36 teachers (60\%) identified they taught flexibility at FFA meetings, 31 advisors (52.5\%) taught the topic in special training, 36 respondents (61\%) taught the topic one-on-one, and three respondents (5.1\%) did not teach the topic (see Table 18).

Passion. Agricultural science teachers were asked the frequency they taught the topic and the importance they place on teaching the topic to their students. Using a scale of 1-6 with 1 being "not important" and 6 "very important" the average rating of the importance of teaching passion was $5.04(\mathrm{SD}=1.18)$ (see Table 17). Five respondents (10\%) taught passion once a year. The topic was taught 2-3 times per year by 17 respondents (34\%), $4-5$ times per year by nine (18\%), and 6 or more times per year by 19 advisors (38\%) (see Table 17).

Respondents were asked where they taught the topic of passion. Thirty-eight respondents (63.3\%) taught passion in the classroom and 30 teachers (50\%) identified they taught passion at FFA meetings, 28 advisors (46.7\%) taught the topic in special training, 36 respondents (60\%) taught the topic one-on-one, and 11 respondents (18\%) did not teach the topic (see Table 18).

Wisdom. Respondents were asked the frequency they taught the topic and the importance they place on teaching the topic to their students. Using a scale of 1-6 with 1 being "not important" and 6 "very important" the average rating of the importance of teaching wisdom was 5.02 ( $\mathrm{SD}=1.11$ ) (see Table 17). Four respondents (7.7\%) taught wisdom once a year. The topic was taught 2-3 times per year by 19 respondents (36.5\%), 
4-5 times per year by 11 (21.2\%), and 6 or more times per year by 18 advisors (34.6\%) (see Table 17).

FFA advisors were asked where they taught the topic of wisdom. Forty-five respondents (76.3\%) taught wisdom in the classroom and 30 teachers (50.8\%) identified they taught wisdom at FFA meetings, 25 advisors (42.4\%) taught the topic in special training, 34 respondents (57.6\%) taught the topic one-on-one, and eight respondents (13.3\%) did not teach the topic (see Table 18).

Forgiveness. Agricultural science teachers were asked the frequency they taught the topic and the importance they place on teaching the topic to their students. Using a scale of 1-6 with 1 being "not important” and 6 "very important” the average rating of the importance of teaching forgiveness was $4.95(\mathrm{SD}=.99)$ (see Table 17). Eight respondents (15.4\%) taught forgiveness once a year. The topic was taught 2-3 times per year by 18 respondents (34.6\%), 4-5 times per year by 10 (19.2\%), and 6 or more times per year by 16 advisors (30.8\%) (see Table 17).

FFA advisors were asked where they taught the topic of forgiveness. Forty respondents (66.7\%) taught forgiveness in the classroom and 28 teachers (46.7\%) identified they taught forgiveness at FFA meetings, 24 advisors (40\%) taught the topic in special training, 37 respondents (61.7\%) taught the topic one-on-one, and eight respondents (13.1\%) did not teach the topic (see Table 18).

Risk-taking. Agricultural science teachers were asked the frequency they taught the topic and the importance they place on teaching the topic to their students. Using a scale of 1-6 with 1 being "not important” and 6 "very important” the average rating of the importance of teaching risk-taking was $4.80(\mathrm{SD}=1.17)$ (see Table 17). Seven 
respondents (13.2\%) taught risk-taking once a year. The topic was taught 2-3 times per year by 21 respondents (39.6\%), 4-5 times per year by eight (15.1\%), and 6 or more times per year by 17 advisors (32.1\%) (see Table 17).

Respondents were asked where they taught the topic of risk-taking. Forty-nine respondents (81.7\%) taught risk-taking in the classroom and 27 teachers (45\%) identified they taught risk-taking at both FFA meetings and in special training, 28 respondents (46.7\%) taught the topic one-on-one, and nine respondents (14.8\%) did not teach the topic (see Table 18).

Humility. Respondents were asked the frequency they taught the topic and the importance they place on teaching the topic to their students. Using a scale of 1-6 with 1 being "not important" and 6 "very important" the average rating of the importance of teaching humility was 4.79 (SD =1.19) (see Table 17$)$. Six respondents (11.8\%) taught humility once a year. The topic was taught 2-3 times per year by 17 respondents (33.3\%), $4-5$ times per year by 14 (27.5\%), and 6 or more times per year by 14 advisors (27.5\%) (see Table 17).

FFA advisors were asked where they taught the topic of humility. Forty-three respondents (71.7\%) taught humility in the classroom and 25 teachers (41\%) identified they taught humility at FFA meetings, 24 advisors (40\%) taught the topic in special training, 34 respondents (56.7\%) taught the topic one-on-one, and nine respondents (15\%) did not teach the topic (see Table 18).

Importance, Frequency, and Location of Instruction of Written Communication Skills

Writing a speech. Respondents were asked the frequency they taught the skill and the importance they place on teaching the skill to their students. Using a scale of 1-6 
with 1 being "not important" and 6 "very important" the average rating of the importance of teaching writing a speech was 5.15 (SD =.89) (see Table 19). Nine respondents (15\%) taught writing a speech once a year. The skill was taught 2-3 times per year by 12 respondents (20\%), 4-5 times per year by 18 (30\%), and 6 or more times per year by 21 advisors (35\%) (see Table 19).

FFA advisors were asked where they taught the skill of writing a speech. Fifty respondents (82\%) taught writing a speech in the classroom and 29 teachers (47.5\%) identified they taught writing a speech at FFA meetings, 31 advisors (50.8\%) taught the skill in special training, 39 respondents (63.9\%) taught the skill one-on-one, and one respondent (1.6\%) did not teach the skill (see Table 20). 
Table 19

Importance \& Frequency of Written Communication Skills

\begin{tabular}{|c|c|c|c|c|c|c|c|c|c|c|}
\hline & \multirow{2}{*}{\multicolumn{2}{|c|}{ Importance }} & \multicolumn{8}{|c|}{ Frequency } \\
\hline & & & \multicolumn{2}{|c|}{$\begin{array}{l}1 \text { time per } \\
\text { year }\end{array}$} & \multicolumn{2}{|c|}{$\begin{array}{l}2-3 \text { times } \\
\text { per year }\end{array}$} & \multicolumn{2}{|c|}{$\begin{array}{l}4-5 \text { times } \\
\text { per year }\end{array}$} & \multicolumn{2}{|c|}{$\begin{array}{l}6 \text { or more } \\
\text { times per } \\
\text { year }\end{array}$} \\
\hline & $M$ & $S D$ & $N$ & $\%$ & $N$ & $\%$ & $N$ & $\%$ & $N$ & $\%$ \\
\hline Writing a speech & 5.15 & .89 & 9 & 15.0 & 12 & 20.0 & 18 & 30.0 & 21 & 35.0 \\
\hline Writing thank you letters & 5.14 & 1.08 & 14 & 24.1 & 13 & 22.4 & 10 & 17.2 & 21 & 36.2 \\
\hline $\begin{array}{l}\text { Getting local newspapers } \\
\text { to publish your news } \\
\text { releases }\end{array}$ & 4.98 & 1.05 & 6 & 11.3 & 18 & 34.0 & 9 & 17.0 & 20 & 37.7 \\
\hline Writing news releases & 4.71 & 1.06 & 4 & 7.1 & 30 & 53.6 & 6 & 10.7 & 16 & 28.6 \\
\hline Writing business letters & 4.68 & 1.16 & 9 & 17.3 & 22 & 42.3 & 10 & 19.2 & 11 & 21.2 \\
\hline $\begin{array}{l}\text { Creating PowerPoint } \\
\text { presentations }\end{array}$ & 4.64 & 1.16 & 7 & 14.3 & 11 & 22.4 & 13 & 26.5 & 18 & 36.7 \\
\hline Writing meeting minutes & 4.42 & 1.27 & 12 & 20.3 & 25 & 42.4 & 4 & 6.8 & 18 & 30.5 \\
\hline $\begin{array}{l}\text { Making handouts for } \\
\text { your presentations }\end{array}$ & 4.26 & 1.41 & 7 & 12.5 & 20 & 35.7 & 11 & 19.6 & 18 & 32.1 \\
\hline $\begin{array}{l}\text { Taking great } \\
\text { photographs }\end{array}$ & 4.20 & 1.39 & 14 & 27.5 & 10 & 19.6 & 9 & 17.6 & 18 & 35.3 \\
\hline Using graphics & 4.19 & 1.27 & 11 & 24.4 & 15 & 33.3 & 7 & 15.6 & 12 & 26.7 \\
\hline $\begin{array}{l}\text { Writing committee } \\
\text { reports }\end{array}$ & 4.19 & 1.23 & 15 & 28.3 & 21 & 39.6 & 8 & 15.1 & 9 & 17.0 \\
\hline $\begin{array}{l}\text { Creating an awesome } \\
\text { scrapbook }\end{array}$ & 3.87 & 1.59 & 17 & 34.7 & 16 & 32.7 & 8 & 16.3 & 8 & 16.3 \\
\hline $\begin{array}{l}\text { Designing attractive web } \\
\text { pages }\end{array}$ & 3.78 & 1.50 & 12 & 36.4 & 11 & 33.3 & 6 & 18.2 & 4 & 12.1 \\
\hline Writing a workshop & 3.51 & 1.67 & 14 & 31.8 & 17 & 38.6 & 6 & 13.6 & 7 & 15.9 \\
\hline
\end{tabular}


Table 20

Location Written Communication Skills are Taught

\begin{tabular}{|c|c|c|c|c|}
\hline & \multicolumn{2}{|c|}{ Not Taught } & \multicolumn{2}{|c|}{ Taught } \\
\hline & $N$ & $\%$ & $N$ & $\%$ \\
\hline \multicolumn{5}{|c|}{$\begin{array}{l}\text { Making handouts for your } \\
\text { presentations }\end{array}$} \\
\hline Classroom & 19 & 32.2 & 40 & 67.8 \\
\hline FFA Meeting & 38 & 64.4 & 21 & 35.6 \\
\hline Special Training & 38 & 64.4 & 21 & 35.6 \\
\hline One-on-one & 44 & 74.6 & 15 & 25.4 \\
\hline Not at all & 54 & 91.5 & 5 & 8.5 \\
\hline \multicolumn{5}{|c|}{ Writing meeting minutes } \\
\hline Classroom & 47 & 77.0 & 14 & 23.0 \\
\hline FFA Meeting & 34 & 55.7 & 27 & 44.3 \\
\hline Special Training & 33 & 54.1 & 28 & 45.9 \\
\hline One-on-one & 36 & 59.0 & 25 & 41.0 \\
\hline Not at all & 59 & 96.7 & 2 & 3.3 \\
\hline \multicolumn{5}{|l|}{ Writing a workshop } \\
\hline Classroom & 44 & 73.3 & 16 & 26.7 \\
\hline FFA Meeting & 47 & 78.3 & 13 & 21.7 \\
\hline Special Training & 33 & 55.0 & 27 & 45.0 \\
\hline One-on-one & 44 & 73.3 & 16 & 26.7 \\
\hline Not at all & 39 & 65.0 & 21 & 35.0 \\
\hline
\end{tabular}


Table 20 (Continued)

Location Written Communication Skills are Taught

\begin{tabular}{|c|c|c|c|c|}
\hline & \multicolumn{2}{|c|}{ Not Taught } & \multicolumn{2}{|c|}{ Taught } \\
\hline & $N$ & $\%$ & $N$ & $\%$ \\
\hline \multicolumn{5}{|l|}{ Using graphics } \\
\hline Classroom & 20 & 33.9 & 39 & 66.1 \\
\hline FFA Meeting & 40 & 67.8 & 19 & 32.2 \\
\hline Special Training & 38 & 64.4 & 21 & 35.6 \\
\hline One-on-one & 46 & 78.0 & 13 & 22.0 \\
\hline Not at all & 44 & 74.6 & 15 & 25.4 \\
\hline \multicolumn{5}{|l|}{ Writing a speech } \\
\hline Classroom & 11 & 18.0 & 50 & 82.0 \\
\hline FFA Meeting & 32 & 52.5 & 29 & 47.5 \\
\hline Special Training & 30 & 49.2 & 31 & 50.8 \\
\hline One-on-one & 22 & 36.1 & 39 & 63.9 \\
\hline Not at all & 60 & 98.4 & 1 & 1.6 \\
\hline \multicolumn{5}{|c|}{ Writing thank you letters } \\
\hline Classroom & 23 & 37.7 & 38 & 62.3 \\
\hline FFA Meeting & 27 & 44.3 & 34 & 55.7 \\
\hline Special Training & 30 & 49.2 & 31 & 50.8 \\
\hline One-on-one & 23 & 37.7 & 38 & 62.3 \\
\hline Not at all & 59 & 96.7 & 2 & 3.3 \\
\hline
\end{tabular}


Table 20 (Continued)

Location Written Communication Skills are Taught

\begin{tabular}{|c|c|c|c|c|}
\hline & \multicolumn{2}{|c|}{ Not Taught } & \multicolumn{2}{|c|}{ Taught } \\
\hline & $N$ & $\%$ & $N$ & $\%$ \\
\hline \multicolumn{5}{|l|}{ Writing business letters } \\
\hline Classroom & 17 & 27.9 & 44 & 72.1 \\
\hline FFA Meeting & 49 & 80.3 & 12 & 19.7 \\
\hline Special Training & 44 & 72.1 & 17 & 27.9 \\
\hline One-on-one & 37 & 60.7 & 24 & 39.3 \\
\hline Not at all & 55 & 90.2 & 6 & 9.8 \\
\hline \multicolumn{5}{|c|}{ Taking great photographs } \\
\hline Classroom & 38 & 63.3 & 22 & 36.7 \\
\hline FFA Meeting & 35 & 58.3 & 25 & 41.7 \\
\hline Special Training & 34 & 56.7 & 26 & 43.3 \\
\hline One-on-one & 25 & 41.7 & 35 & 58.3 \\
\hline Not at all & 52 & 86.7 & 8 & 13.3 \\
\hline \multicolumn{5}{|c|}{ Creating an awesome scrapbook } \\
\hline Classroom & 49 & 80.3 & 12 & 19.7 \\
\hline FFA Meeting & 41 & 67.2 & 20 & 32.8 \\
\hline Special Training & 43 & 70.5 & 18 & 29.5 \\
\hline One-on-one & 29 & 47.5 & 32 & 52.5 \\
\hline Not at all & 48 & 78.7 & 13 & 21.3 \\
\hline
\end{tabular}


Table 20 (Continued)

Location Written Communication Skills are Taught

\begin{tabular}{|c|c|c|c|c|}
\hline & \multicolumn{2}{|c|}{ Not Taught } & \multicolumn{2}{|c|}{ Taught } \\
\hline & $N$ & $\%$ & $N$ & $\%$ \\
\hline \multicolumn{5}{|c|}{ Designing attractive web pages } \\
\hline Classroom & 43 & 71.7 & 17 & 28.3 \\
\hline FFA Meeting & 54 & 90.0 & 6 & 10.0 \\
\hline Special Training & 51 & 85.0 & 9 & 15.0 \\
\hline One-on-one & 43 & 71.7 & 17 & 28.3 \\
\hline Not at all & 28 & 46.7 & 32 & 53.3 \\
\hline \multicolumn{5}{|c|}{ Writing committee reports } \\
\hline Classroom & 42 & 68.9 & 19 & 31.1 \\
\hline FFA Meeting & 29 & 47.5 & 32 & 52.5 \\
\hline Special Training & 36 & 59.0 & 25 & 41.0 \\
\hline One-on-one & 37 & 60.7 & 24 & 39.3 \\
\hline Not at all & 50 & 82.0 & 11 & 18.0 \\
\hline \multicolumn{5}{|c|}{ Creating PowerPoint presentations } \\
\hline Classroom & 18 & 29.5 & 43 & 70.5 \\
\hline FFA Meeting & 42 & 68.9 & 19 & 31.1 \\
\hline Special Training & 41 & 67.2 & 20 & 32.8 \\
\hline One-on-one & 31 & 50.8 & 30 & 49.2 \\
\hline Not at all & 50 & 82.0 & 11 & 18.0 \\
\hline
\end{tabular}


Table 20 (Continued)

Location Written Communication Skills are Taught

\begin{tabular}{|c|c|c|c|c|}
\hline & \multicolumn{2}{|c|}{ Not Taught } & \multicolumn{2}{|c|}{ Taught } \\
\hline & $N$ & $\%$ & $N$ & $\%$ \\
\hline \multicolumn{5}{|l|}{ Writing news releases } \\
\hline Classroom & 34 & 55.7 & 27 & 44.3 \\
\hline FFA Meeting & 36 & 59.0 & 25 & 41.0 \\
\hline Special Training & 35 & 57.4 & 26 & 42.6 \\
\hline One-on-one & 26 & 42.6 & 35 & 57.4 \\
\hline Not at all & 57 & 93.4 & 4 & 6.6 \\
\hline \multicolumn{5}{|c|}{$\begin{array}{l}\text { Getting local newspapers to } \\
\text { publish your news releases }\end{array}$} \\
\hline Classroom & 40 & 66.7 & 20 & 33.3 \\
\hline FFA Meeting & 37 & 61.7 & 23 & 38.3 \\
\hline Special Training & 35 & 58.3 & 25 & 41.7 \\
\hline One-on-one & 25 & 41.7 & 35 & 58.3 \\
\hline Not at all & 54 & 90.0 & 6 & 10.0 \\
\hline
\end{tabular}

Writing thank you letters. Agricultural science teachers were asked the frequency they taught the skill and the importance they place on teaching the skill to their students. Using a scale of 1-6 with 1 being "not important” and 6 "very important" the average rating of the importance of teaching writing thank you letters was 5.14 (SD =1.08) (see Table 19). Fourteen respondents (24.1\%) taught writing thank you letters once a year. The skill was taught 2-3 times per year by 13 respondents (22.4\%), 4-5 times per year by 10 (17.2\%), and 6 or more times per year by 21 advisors (36.2\%) (see Table 19). 
Respondents were asked where they taught the skill of writing thank you letters. Thirty-eight respondents (62.3\%) taught writing thank you letters in the classroom and 34 teachers (55.7\%) identified they taught writing thank you letters at FFA meetings, 31 advisors (50.8\%) taught the skill in special training, 38 respondents (62.3\%) taught the skill one-on-one, and two respondents (3.3\%) did not teach the skill (see Table 20).

Getting local newspapers to publish your news releases. FFA advisors were asked the frequency they taught the skill and the importance they place on teaching the skill to their students. Using a scale of 1-6 with 1 being "not important" and 6 "very important" the average rating of the importance of teaching getting local newspapers to publish your news releases was $4.98(\mathrm{SD}=1.05)$ (see Table 19). Six respondents (11.3\%) taught getting local newspapers to publish your news releases once a year. The skill was taught 2-3 times per year by 18 respondents (34\%), 4-5 times per year by nine (17\%), and 6 or more times per year by 20 advisors (37.7\%) (see Table 19).

Agricultural science teachers were asked where they taught the skill of getting local newspapers to publish your news releases. Twenty respondents (33.3\%) taught getting local newspapers to publish your news releases in the classroom and 23 teachers (38.3\%) identified they taught getting local newspapers to publish your news releases at FFA meetings, 25 advisors (41.7\%) taught the skill in special training, 35 respondents (58.3\%) taught the skill one-on-one, and six respondents (10\%) did not teach the skill (see Table 20).

Writing news releases. Respondents were asked the frequency they taught the skill and the importance they place on teaching the skill to their students. Using a scale of 1-6 with 1 being "not important" and 6 "very important" the average rating of the 
importance of teaching writing news releases was $4.71(\mathrm{SD}=1.06)$ (see Table 19). Four respondents (7.1\%) taught writing news releases once a year. The skill was taught 2-3 times per year by 30 respondents (53.6\%), 4-5 times per year by six (10.7\%), and 6 or more times per year by 16 advisors (28.6\%) (see Table 19).

Agricultural science teachers were asked where they taught the skill of writing news releases. Twenty-seven respondents (44.3\%) taught writing news releases in the classroom and 25 teachers (41\%) identified they taught writing news releases at FFA meetings, 26 advisors (42.6\%) taught the skill in special training, 35 respondents (57.4\%) taught the skill one-on-one, and four respondents (6.6\%) did not teach the skill (see Table 20).

Writing business letters. Agricultural science teachers were asked the frequency they taught the skill and the importance they place on teaching the skill to their students. Using a scale of 1-6 with 1 being “not important” and 6 "very important” the average rating of the importance of teaching writing business letters was 4.68 (SD =1.16) (see Table 19). Nine respondents (17.3\%) taught writing business letters once a year. The skill was taught 2-3 times per year by 22 respondents (42.3\%), 4-5 times per year by 10 (19.2\%), and 6 or more times per year by 11 advisors (21.2\%) (see Table 19).

FFA advisors were asked where they taught the skill of writing business letters. Forty-four respondents (72.1\%) taught writing business letters in the classroom and 12 teachers (19.7\%) identified they taught writing business letters at FFA meetings, 17 advisors (27.9\%) taught the skill in special training, 24 respondents (39.3\%) taught the skill one-on-one, and six respondents (9.8\%) did not teach the skill (see Table 20). 
Creating PowerPoint presentations. Agricultural science teachers were asked the frequency they taught the skill and the importance they place on teaching the skill to their students. Using a scale of 1-6 with 1 being "not important" and 6 "very important" the average rating of the importance of teaching creating PowerPoint presentations was 4.64 (SD =1.16) (see Table 19). Seven respondents (14.3\%) taught creating PowerPoint presentations once a year. The skill was taught 2-3 times per year by 11 respondents (22.4\%), 4-5 times per year by 13 (26.5\%), and 6 or more times per year by 18 advisors (36.7\%) (see Table 19).

Respondents were asked where they taught the skill of creating PowerPoint presentations. Forty-three respondents (70.5\%) taught creating PowerPoint presentations in the classroom and 19 teachers (31.1\%) identified they taught creating PowerPoint presentations at FFA meetings, 20 advisors (32.8\%) taught the skill in special training, 30 respondents (49.2\%) taught the skill one-on-one, and 11 respondents (18\%) did not teach the skill (see Table 20).

Writing meeting minutes. FFA advisors were asked the frequency they taught the skill and the importance they place on teaching the skill to their students. Using a scale of 1-6 with 1 being "not important" and 6 "very important" the average rating of the importance of teaching writing meeting minutes was $4.42(\mathrm{SD}=1.27$ ) (see Table 19). Twelve respondents (20.3\%) taught writing meeting minutes once a year. The skill was taught 2-3 times per year by 25 respondents (42.4\%), 4-5 times per year by four (6.8\%), and 6 or more times per year by 18 advisors (30.5\%) (see Table 19 ).

Agricultural science teachers were asked where they taught the skill of writing meeting minutes. Fourteen respondents (23\%) taught writing meeting minutes in the 
classroom and 27 teachers (44.3\%) identified they taught writing meeting minutes at FFA meetings, 28 advisors (45.9\%) taught the skill in special training, 25 respondents (41\%) taught the skill one-on-one, and two respondents (3.3\%) did not teach the skill (see Table 20).

Making handouts for your presentations. Respondents were asked the frequency they taught the skill and the importance they place on teaching the skill to their students. Using a scale of 1-6 with 1 being “not important” and 6 "very important” the average rating of the importance of teaching making handouts for your presentations was 4.26 $(\mathrm{SD}=1.41)$ (see Table 19). Seven respondents (12.5\%) taught making handouts for your presentations once a year. The skill was taught 2-3 times per year by 20 respondents (35.7\%), 4-5 times per year by 11 (19.6\%), and 6 or more times per year by 18 advisors (32.1\%) (see Table 19).

FFA advisors were asked where they taught the skill of making handouts for your presentations. Forty respondents (67.8\%) taught making handouts for your presentations in the classroom and 21 teachers (35.6\%) identified they taught making handouts for your presentations both at FFA meetings and in special training, 15 respondents (25.4\%) taught the skill one-on-one, and five respondents (8.5\%) did not teach the skill (see Table 20).

Taking great photographs. FFA advisors were asked the frequency they taught the skill and the importance they place on teaching the skill to their students. Using a scale of 1-6 with 1 being "not important" and 6 "very important” the average rating of the importance of teaching taking great photographs was 4.20 (SD =1.39) (see Table 19). Fourteen respondents (27.5\%) taught taking great photographs once a year. The skill was 
taught 2-3 times per year by 10 respondents (19.6\%), 4-5 times per year by nine (17.6\%), and 6 or more times per year by 18 advisors (35.3\%) (see Table 19).

Respondents were asked where they taught the skill of taking great photographs. Twenty-two respondents (36.7\%) taught taking great photographs in the classroom and 25 teachers (41.7\%) identified they taught taking great photographs at FFA meetings, 26 advisors (43.3\%) taught the skill in special training, 35 respondents (58.3\%) taught the skill one-on-one, and eight respondents (13.3\%) did not teach the skill (see Table 20).

Using graphics. Agricultural science teachers were asked the frequency they taught the skill and the importance they place on teaching the skill to their students. Using a scale of 1-6 with 1 being "not important" and 6 "very important" the average rating of the importance of teaching using graphics was $4.19(\mathrm{SD}=1.27)$ (see Table 19). Eleven respondents (24.4\%) taught using graphics once a year. The skill was taught 2-3 times per year by 15 respondents (33.3\%), 4-5 times per year by seven (15.6\%), and 6 or more times per year by 12 advisors (26.7\%) (see Table 19).

FFA advisors were asked where they taught the skill of using graphics. Thirtynine respondents (66.1\%) taught using graphics in the classroom and 19 teachers (32.2\%) identified they taught using graphics at FFA meetings, 21 advisors (35.6\%) taught the skill in special training, 13 respondents (22\%) taught the skill one-on-one, and 15 respondents (25.4\%) did not teach the skill (see Table 20).

Writing committee reports. Agricultural science teachers were asked the frequency they taught the skill and the importance they place on teaching the skill to their students. Using a scale of 1-6 with 1 being "not important" and 6 "very important" the average rating of the importance of teaching writing committee reports was 4.19 (SD 
=1.23) (see Table 19). Fifteen respondents (28.3\%) taught writing committee reports once a year. The skill was taught 2-3 times per year by 21 respondents (39.6\%), 4-5 times per year by eight (15.1\%), and 6 or more times per year by nine advisors (17\%) (see Table 19).

Respondents were asked where they taught the skill of writing committee reports. Thirty-nine respondents (66.1\%) taught writing committee reports in the classroom and 19 teachers (32.2\%) identified they taught writing committee reports at FFA meetings, 21 advisors (35.6\%) taught the skill in special training, 13 respondents (22\%) taught the skill one-on-one, and 15 respondents (25.4\%) did not teach the skill (see Table 20).

Creating an awesome scrapbook. Respondents were asked the frequency they taught the skill and the importance they place on teaching the skill to their students. Using a scale of 1-6 with 1 being "not important" and 6 "very important" the average rating of the importance of teaching creating an awesome scrapbook was 3.87 (SD =1.59) (see Table 19). Seventeen respondents (34.7\%) taught creating an awesome scrapbook once a year. The skill was taught 2-3 times per year by 16 respondents (32.7\%), 4-5 times per year and 6 or more times per year by eight advisors (16.3\%) (see Table 19). FFA advisors were asked where they taught the skill of creating an awesome scrapbook. Twelve respondents (19.7\%) taught creating an awesome scrapbook in the classroom and 20 teachers (32.8\%) identified they taught creating an awesome scrapbook at FFA meetings, 18 advisors (29.5\%) taught the skill in special training, 32 respondents (52.5\%) taught the skill one-on-one, and 13 respondents (21.3\%) did not teach the skill (see Table 20). 
Designing attractive web pages. Agricultural science teachers were asked the frequency they taught the skill and the importance they place on teaching the skill to their students. Using a scale of 1-6 with 1 being "not important" and 6 "very important" the average rating of the importance of teaching designing attractive web pages was 3.78 (SD $=1.50$ ) (see Table 19). Twelve respondents (36.4\%) taught designing attractive web pages once a year. The skill was taught 2-3 times per year by 11 respondents (33.3\%), 45 times per year by six (18.2\%), and 6 or more times per year by four advisors (12.1\%) (see Table 19).

FFA advisors were asked where they taught the skill of designing attractive web pages. Seventeen respondents (28.3\%) taught designing attractive web pages in the classroom and six teachers (10\%) identified they taught designing attractive web pages at FFA meetings, nine advisors (15\%) taught the skill in special training, 17 respondents (28.3\%) taught the skill one-on-one, and 32 respondents (53.3\%) did not teach the skill (see Table 20).

Writing a workshop. Respondents were asked the frequency they taught the skill and the importance they place on teaching the skill to their students. Using a scale of 1-6 with 1 being "not important" and 6 "very important" the average rating of the importance of teaching writing a workshop was $3.51(\mathrm{SD}=1.67)$ (see Table 19). Fourteen respondents (31.8\%) taught writing a workshop once a year. The skill was taught 2-3 times per year by 17 respondents (38.6\%), 4-5 times per year by six (13.6\%), and 6 or more times per year by seven advisors (15.9\%) (see Table 19).

Agricultural science teachers were asked where they taught the skill of writing a workshop. Sixteen respondents (26.7\%) taught writing a workshop in the classroom and 
13 teachers (21.7\%) identified they taught writing a workshop at FFA meetings, 27 advisors (45\%) taught the skill in special training, 16 respondents (26.7\%) taught the skill one-on-one, and 21 respondents (35\%) did not teach the skill (see Table 20). Sources of Leadership Training Assistance

Agricultural science teachers were asked to identify who assists them in their leadership training. Fifty-three FFA advisors (85.0\%) utilize the help of Chapter FFA officers in leadership training (see Table 21). Forty-one respondents (66.1\%) have assistance from state FFA officers, while 31 FFA advisors (50.0\%) use the help of past chapter officers. Thirty agricultural science teachers (48.4\%) utilize assistance from chapter alumni, 23 FFA advisors (37.1\%) from regional FFA officers, and 17 respondents (27.4\%) from their advisory committee. Agricultural science teachers in the survey also had the option of selecting other to identify areas they receive assistance that were not included in the survey. Sixteen teachers (25.8\%) obtained assistance from another area. Three respondents (4.8\%) were aided by university faculty and two teachers (3.3\%) identified they received leadership training assistance from each of the following areas; other agriculture science teachers, parents, and state staff. Three agricultural science teachers (4.8\%) said they used no assistance in leadership training. 
Table 21

Sources of Leadership Training Assistance

\begin{tabular}{|c|c|c|c|c|}
\hline & \multicolumn{2}{|c|}{ No } & \multicolumn{2}{|c|}{ Yes } \\
\hline & $N$ & $\%$ & $N$ & $\%$ \\
\hline Chapter FFA Officers & 9 & 14.5 & 53 & 85.5 \\
\hline State FFA Officers & 21 & 33.9 & 41 & 66.1 \\
\hline Past Chapter FFA Officers & 31 & 50.0 & 31 & 50.0 \\
\hline Chapter Alumni & 32 & 51.6 & 30 & 48.4 \\
\hline Regional FFA Officers & 39 & 62.9 & 23 & 37.1 \\
\hline Advisory Committee & 45 & 72.6 & 17 & 27.4 \\
\hline Other & 46 & 74.4 & 16 & 25.8 \\
\hline University Faculty & 59 & 95.2 & 3 & 4.8 \\
\hline Other Ag Teachers & 60 & 96.7 & 2 & 3.3 \\
\hline Parents & 60 & 96.7 & 2 & 3.3 \\
\hline State Staff & 60 & 96.7 & 2 & 3.3 \\
\hline No Assistance & 59 & 95.2 & 3 & 4.8 \\
\hline
\end{tabular}




\section{CHAPTER V}

\section{Summary, Conclusions, and Recommendations}

\section{Purpose of Study}

The purpose of this study was to determine the importance of different leadership skills taught to agriculture students and FFA members at the chapter level, where students and members receive leadership training, the frequency of training, and the instructors that provide leadership training.

\section{Objectives of the Study}

The objectives of this study were to determine types, frequencies, importance, and location of leadership training or education provided at the chapter FFA level. As a means of developing this study answers to the following questions were sought:

1. In what contexts do agricultural science instructors provide leadership training?

2. What leadership skills do agricultural science instructors consider most important for agriculture students to receive training or instruction?

3. How often agriculture students are provided training for specific skills?

4. Who assists agricultural science instructors in providing leadership training at the chapter level?

\section{Summary of Findings}

The sample population for this study was 233 agricultural science teachers who served as FFA advisors of chapters that were recognized in the National Chapter Award Program at the $78^{\text {th }}$ National FFA Convention. On average the agriculture of programs represented in this study had a high school enrollment of 820 students, approximately 160 
students enrolled in the high school agriculture program with an FFA membership of 136. These agriculture programs typically have two teachers.

Skills that were identified as appearance qualities where predominately taught 2-3 times per year, professional dress was the topic identified as being taught most frequently at 6 or more times per year. Four of the five skills (professional dress, personal hygiene and attire, utilizing proper travel etiquette, and using proper dining etiquette) were identified as being important, with tying a tie being somewhat important. These skills were also most likely to be taught one-on-one with the exception of professional dress. Three/fourths of the respondents taught professional dress in the classroom and at FFA meetings.

Creating executive meetings that your fellow officers will not want to miss was rated important with the other five creative thinking skills (banquet ideas that work, great meeting activities — mixers, icebreakers, \& energizers, enhancing your creativity, generating great ideas for skits, meeting activities, \& presentations, and creating super slide shows) being somewhat important. Creative thinking skills were predominately taught 2-3 times per year. About two-third of the respondents taught creating executive meetings that your fellow officer will not want to miss at FFA meetings. The same number also identified they taught great meeting activities -mixers, icebreakers, \& energizers at FFA meetings and special training, enhancing your creativity in the classroom, and banquet ideas that work in the classroom.

One of the seven educational material skills, opportunities in the FFA, was ranked very important. The other six were split with three rated important (agriculture issues, organizational structure, and agricultural education issues) and three rated somewhat 
important (leadership levels, leadership styles, and learning styles). Educational material skills were most likely to be taught 2-3 times per year. Over two-third of the agriculture teachers responding taught each of the seven educational material skills in the classroom and three of the skills (opportunities in FFA, organizational structure, and leadership levels) were taught in FFA meetings by over half of the respondents.

Thirteen of the fifteen leadership ability scores (being a role model in your chapter, motivating members, practicing proper parliamentary procedure, creating partnerships with community and industry leaders, running an effective meeting, encouraging others, delegating so that the work gets done, leading an activity, expressing your opinion so that others listen, facilitating a meeting or discussion, characteristics of an effective team player, utilizing situational leadership, and qualities of an influential leader) were identified as being important with the remaining two (dealing with difficult members at your meetings and types and uses of power) rated as somewhat important. Almost all of the leadership ability skills were taught 6 or more times per year by the respondents. Three skills in this category (running an effective meeting, motivating members, and qualities of an influential leader) were identified as being taught by every agriculture science teacher in the study. All but one skill, dealing with difficult members at your meetings, was taught in the classroom by over $60 \%$ of the FFA advisors in the study. All but three of the skills (dealing with difficult members at your meetings, types and uses of power, and qualities of an influential leader) were taught in an FFA meeting or special training by over half of the respondents.

Of the eleven skills in the oral communication skills category seven were rated important (delivering a speech, giving clear directions, presenting powerful ceremonies, 
developing and delivering powerful key messages, utilizing effective telephone etiquette, using audio-visual equipment in your presentations, and establishing and maintaining conversations) and the remaining four (introducing a speaker, presenting awards, creating welcoming remarks, and using a microphone effectively) were found to be important. Delivering a speech and presenting powerful ceremonies were most frequently reported as taught 6 or more times per year. The other nine skills were predominately taught 2-3 times per year. Delivering a speech was taught by all agriculture science teachers in the study. Giving clear directions, delivering a speech, utilizing effective telephone etiquette, and using audio-visual equipment in your presentations were taught in the classroom by over two-thirds of the respondents.

Thirteen out of sixteen personal skills (being responsible, effective listening, improving self confidence, managing your time effectively, creating a great first impression, relationship building, managing your life, accepting constructive criticism, keys to personal success, clarifying personal value, networking, using the internet, and managing stress) were rated as important and the remaining three (shaking hands the proper way, communicating without words (non-verbal), and remembering names) were somewhat important. Personal skills are predominately taught 6 or more times per year. Improving self confidence was taught by all of the respondents. All of the skills were taught in the classroom by at least half of the agriculture science teachers in the study. Effective listening, communicating without words (non-verbal), clarifying personal value, managing your time effectively, being responsible, creating a great first impression, and keys to personal success are taught in the classroom by over threefourths of the respondents. 
Of the eleven planning and teamwork skills, teamwork was the only one rated very important; this skill also received the highest importance rating in the study. Eight of the eleven planning and teamwork skills (setting personal or team goals, solving problems, setting priorities, resolving conflict on your team or in your chapter, how to build a powerful team, planning an activity, developing a program of work, and creating a budget) were rated important and the remaining two (group dynamics and writing team or individual mission statements) were found to be somewhat important. Teamwork, setting personal or team goals, solving problems, setting priorities, and planning an activity were most likely to be taught 6 or more times per year, the other skills 2-3 times per year. Planning an activity was taught by all teachers in the study, approximately three-fourths taught the skill in the classroom and at an FFA meeting and half of the respondents taught the skill at a special training and one-on-one. Over two-thirds of the respondents taught teamwork in the classroom, at an FFA meeting, during special training, and one-on-one. Six planning and teamwork skills (planning an activity, setting priorities, solving problems, setting personal or team goals, creating a budget, and group dynamics) were taught in the classroom by two-third of the agriculture science teachers in the study.

All 14 of the leadership quality skills were rated important, with commitment rated the highest. These skills are predominately taught 6 or more times per year. Seven of the skills (maintaining a positive attitude, cooperation, commitment, integrity, risktaking, lifelong learning, and acceptance of others) were taught in the classroom by over $80 \%$ of the respondents. Two-thirds of the respondents indicated they taught leadership quality skills in the classroom. At least $40 \%$ of the agriculture teachers in the study 
taught every leadership quality skill in all locations; classroom, FFA meeting, special training, and one-on-one.

Six of the fourteen written communication skills (writing a speech, writing thank you letters, getting local newspapers to publish your news releases, writing news releases, writing business letters, and creating PowerPoint presentations) were rated as important by the respondents, the other eight (writing meeting minutes, making handouts for your presentations, taking great photographs, using graphics, writing committee reports, creating an awesome scrapbook, designing attractive web pages, and writing a workshop) were found to be somewhat important. The skills were split on the frequency of instruction with some being mostly 2-3 times per year and five (writing a speech, writing thank you letters, getting local newspapers to publish your news releases, creating PowerPoint presentations, and taking great photographs) being taught 6 or more times per year. At least two-third of the teachers taught making handouts for you presentations, using graphics, writing a speech, writing business letters, and creating PowerPoint presentations in the classroom. At least half of all respondents taught writing thank you letters in all areas; classroom, FFA meeting, special training, and one-on-one.

Half of the respondents in the study had assistance from chapter FFA officers, state FFA officers, and past chapter FFA officers for leadership training within their agriculture program. Chapter FFA officers provided assistance to 85\% of the FFA advisors in the study. Only three agriculture science teachers indicated they had no assistance in leadership training. 


\section{Conclusions}

Based upon the results of this study, the following conclusions were drawn:

1. All of the skills in MPower received a mean average of important or higher.

2. Teamwork had the highest importance rating as identified by agriculture science teachers.

3. The 10 most important skills identified by agriculture science teachers are (in order of importance); teamwork, opportunities in FFA, being responsible, setting personal or team goals, commitment, being a role model in your chapter, cooperation, ethical leadership, solving problems, and effective listening.

4. Over half of the skills in the study were taught 2-3 times per year.

5. Less than half of the skills are taught 6 or more times per year.

6. Running an effective meeting, motivating members, qualities of an influential leader, delivering a speech, and planning an activity were taught by all agricultural science teachers in the study.

7. Classroom instruction is the most common place for leadership skills to be taught, followed by FFA meetings.

8. Chapter FFA officers assist $85 \%$ of the agriculture teachers in leadership training.

9. Two-thirds of the agriculture teachers have assistance in leadership training from state FFA officers. 


\section{Recommendations}

Based on the results of the study the following recommendations are proposed by the researcher:

1. Further research should be conducted to determine the importance of leadership skills, frequency leadership skills are taught, and location leadership skills are taught at the chapter level.

2. This study should be replicated with additional agriculture science teachers across the country.

3. Research should be conducted on the effectiveness of the classroom as a location for leadership skills to be taught.

4. Research should be conducted to determine the effectiveness of using chapter FFA officers to assist in leadership training.

5. Research should be undertaken to investigate teaching strategies used in leadership training.

6. Agriculture science teachers should use the top 10 leadership skills identified through this study as a foundation for leadership training in their program.

7. Agriculture science teachers should acquire MPower and utilize it for teaching leadership within their agriculture science programs.

8. Teacher educators should utilize MPower in training student teachers.

9. National FFA should conduct research to provide validity to the content of their publications. 


\section{REFERENCES}

Bernthal, P.R. \& Wellins, R.S. (2003). Executive summary. Leadership forecast 2003: A benchmark study. Pittsburgh, PA: Development Dimensions International.

Birkenholz, R. J., \& Schumacher, L. G. (1994). Leadership Skills of College of Agriculture Graduates. Journal of Agricultural Education, 35 (4), 1-8.

Cook, G. C., (1947). Handbook on teaching vocational agriculture. Interstate Printing Co., Danville, Ill.

Dormody, T. J., \& Seevers, B. S. (1994). Participation of FFA Members in Leadership Development Activities: A Tri-State Study. Journal of Agricultural Education, 35(4), 42-48.

Florida FFA Association. (n.d.). Retrieved February 3, 2006 from http://www.flaffa.org/leadershipevents.html

Gartin, S. A. (1991). Time to teach leadership. The Agricultural Education Journal, 64(5), $4 \& 6$.

Hamlin, H. M. (1949). Agricultural education in community schools. Interstate Printing Co., Danville, Ill.

Krejcie, R., \& Morgan, D. (1970). Determining sample size for research activities. Educational and Psychological Measurement, 30, 607-610.

Maryland FFA Association. (n.d.). Retrieved September 27, 2005 from http://216.37.219.29/mdffa/SFL/index.htm.

Maxwell, J. C. (1999). The 21 Indispensable Qualities of a Leader. Thomas Nelson Publishers. Nashville, Tennessee.

McKinley, B., Birkenholz, R., \& Stewart, B. (1993). Characteristics and experiences related to the leadership skills of agriculture students in college. Journal of Agricultural Education, 34(3), 76-83.

Merriam Webster. (1996). Merriam Webster's Collegiate Dictionary $10^{\text {th }}$ Edition. Merriam-Webster, Incorporated. Springfield, Massachusetts.

Michigan FFA Association. (n.d.). Retrieved February 3, 2006 from http://www.michiganffa.com/association/conferences/index.shtml.

National FFA Organization. (2005). 2005-2006 Official FFA Manual, Indianapolis, Indiana. 
National FFA Organization. (n.d., A). Quick Facts. Retrieved September 27, 2005 from http://www.ffa.org/about_ffa/index.html.

National FFA Organization. (n.d., B). FFA Statistics. Retrieved March 16, 2006 from http://www.ffa.org/about_ffa/html/ffa_statistics.htm.

National FFA Organization. (n.d., C). Washington Leadership Conference. Retrieved March 16, 2006 from http://www.ffa.org/programs/conferences/html/conf_wlc.htm.

National FFA Organization. (n.d., D). National FFA Organization Conferences. Retrieved September 27, 2005 from http://www.ffa.org/programs/conferences/index.html.

National Vocational Education (Smith-Hughes) Act. (n.d.) Retrieved March 23, 2006 from http://www.cals.ncsu.edu/agexed/sae/smithugh.html.

Pennsylvania FFA Association. (n.d.). Retrieved September 26, 2005 from http://www.paffa.state.pa.us/conf.htm.

Phipps, L. J., \& Cook, G. C. (1952). A handbook on teaching vocational agriculture. Interstate Printing Co., Danville, Ill.

Phipps, L. J., \& Osborne, E. W. (1988). Handbook on agricultural education in public schools, $5^{\text {th }}$ edition. Interstate Printers \& Publishers, Danville, Ill.

Ricketts, J. C. \& Rudd, R. D. (2004). Leadership development factors contributing to the success of former Florida State FFA officers. Journal of Southern Agricultural Education Research, 54(1).

Ricketts, S. C., \& Newcomb, L. H. (1984). Leadership and personal development abilities possessed by high school seniors who are members in superior and non-superior FFA chapters, and by seniors who were never enrolled in vocational agriculture. The Journal of the American Association of Teacher Educators in Agriculture, 25(2), 51-59.

Robinson, J. P., Shaver, P. R., \& Wrightsman, L. S. (1991). Criteria for scale selection and evaluation. In J. P. Robinson, P. R. Shaver, \& L. S. Wrightsman (Eds.). Measures of personality and social psychological attitudes (pp. 1-16) New York: Academic Press.

Rutherford, T. A., Townsend, C. D., Briers, G. E., Cummins, R., \& Conrad, C.R. (2002). Leadership self-perceptions of WLC participants. Journal of Agricultural Education, 43(2) 22-33. 
Scheer, S. D. (1997). Youth leadership and community service: A perfect combination. Leadership Link. (Winter, 1997). Columbus, OH: The Ohio State University Leadership Center.

Skinner, R. R., \& Apling, R. N. (2005). The Carl D. Perkins vocational and technical education act of 1998: background and implementation. CRS Report for Congress. Retrieved March 23, 2006 from http://www.ccsso.org/content/pdfs/Perkins_CRS_Report.pdf

Stodgill, R. M. (1974). Handbook of leadership; a survey of theory and research. New York: The Free Press.

Tennessee FFA Association. (n.d.). Retrieved February 3, 2006 from http://www.tnffa.org/association/camp/index.php

Texas FFA Association. (n.d.). Retrieved February 3, 2006 from http://www.texasffa.org/Calendar/tabid/684/Default.aspx

Townsend, C., \& Carter, R. (1983). The relationship of participation in FFA activities and leadership, citizenship, and cooperation. Journal of the American Association of Teacher Educators in Agriculture, 24(1), 20-25.

Townsend, J. D., \& Carter, R. I. (1982). Experimental evaluation of an instructional packet on leadership and FFA for beginning vocational agriculture students in Iowa. Journal of the American Association of Teacher Educators in Agriculture, 23(3), 19-26.

Vandeever, R. C., and Menefee, M. L. (2006). Human Behavior in Organizations. Pearson Education, Inc., Upper Saddle River, New Jersey.

West Virginia FFA Association. (n.d.). Retrieved September 26, 2005 from http://www.wvffa.org/2004\%20Calendar/January2005.htm.

Wingenbach, G. J., \& Kahler, A. A. (1997). Self-perceived youth leadership and life skills of Iowa FFA members. Journal of Agricultural Education, 38(3). 


\section{APPENDICES}


APPENDIX A

Questionnaire 


\title{
Leadership Development: Which Skills are Important, How Often and Where are They Taught?
}

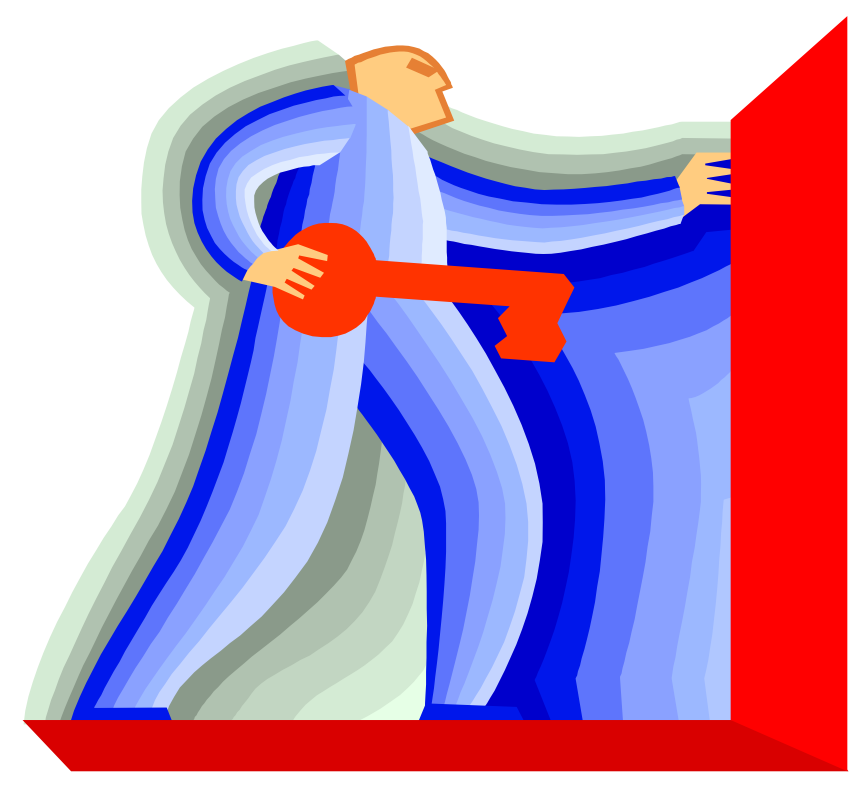

\author{
Nathan Taylor \\ Graduate Student \\ Agricultural and Environmental Education \\ Davis College of Agriculture, Forestry, and Consumer Sciences \\ West Virginia University \\ Morgantown, WV 26506
}




\section{Leadership Development:}

Which Skills are Important, How Often and Where are They Taught?

Instructions: Using the following scales please circle where you teach the following skills, the importance of teaching the skill and the frequency of instruction. (Note: For where, please circle all that apply.)

\begin{tabular}{|c|c|c|c|c|c|c|c|c|c|c|c|c|c|c|}
\hline \multirow[t]{2}{*}{ Skill } & \multicolumn{5}{|c|}{$\begin{array}{l}\text { Where } \\
\text { Where do you } \\
\text { teach the skill? }\end{array}$} & \multicolumn{6}{|c|}{$\begin{array}{l}\text { Importance } \\
\text { How important is it to } \\
\text { teach this skill? }\end{array}$} & \multicolumn{3}{|c|}{$\begin{array}{c}\text { Frequency } \\
\text { How often do } \\
\text { you teach the } \\
\text { skill? }\end{array}$} \\
\hline & $\begin{array}{l}\Xi \\
0 \\
0 \\
5 \\
0 \\
0 \\
0\end{array}$ & 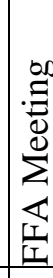 & 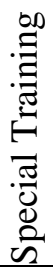 & $\begin{array}{l}\tilde{z} \\
\tilde{0} \\
\tilde{0} \\
\ddot{\sigma} \\
\tilde{\sigma}\end{array}$ & 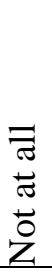 & 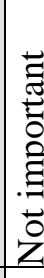 & & & & & 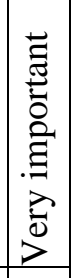 & 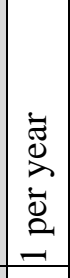 & 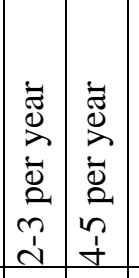 & 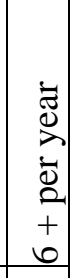 \\
\hline Tying a tie & 1 & 2 & 3 & 4 & 5 & 1 & 2 & 3 & 4 & 5 & 6 & 1 & $2-34-5$ & $6+$ \\
\hline $\begin{array}{l}\text { Making handouts for your } \\
\text { presentations }\end{array}$ & 1 & 2 & 3 & 4 & 5 & 1 & 2 & 3 & 4 & 5 & 6 & 1 & $2-34-5$ & $6+$ \\
\hline $\begin{array}{l}\text { Resolving conflict on your team } \\
\text { or in your chapter }\end{array}$ & 1 & 2 & 3 & 4 & 5 & 1 & 2 & 3 & 4 & 5 & 6 & 1 & $2-3 \mid 4-5$ & $6+$ \\
\hline Writing meeting minutes & 1 & 2 & 3 & 4 & 5 & 1 & 2 & 3 & 4 & 5 & 6 & 1 & $2-34-5$ & $6+$ \\
\hline $\begin{array}{l}\text { Generating great ideas for skits, } \\
\text { meeting activities, and } \\
\text { presentations }\end{array}$ & 1 & 2 & 3 & 4 & 5 & 1 & 2 & 3 & 4 & 5 & 6 & 1 & $2-3|4-5|$ & $6+$ \\
\hline Effective listening & 1 & 2 & 3 & 4 & 5 & 1 & 2 & 3 & 4 & 5 & 6 & 1 & $2-34-5$ & $6+$ \\
\hline Planning an activity & 1 & 2 & 3 & 4 & 5 & 1 & 2 & 3 & 4 & 5 & 6 & 1 & $2-34-5$ & $6+$ \\
\hline $\begin{array}{l}\text { Communicating without words } \\
\text { (non-verbal) }\end{array}$ & 1 & 2 & 3 & 4 & 5 & 1 & 2 & 3 & 4 & 5 & 6 & 1 & $2-34-5$ & $6+$ \\
\hline Introducing a speaker & 1 & 2 & 3 & 4 & 5 & 1 & 2 & 3 & 4 & 5 & 6 & 1 & $2-34-5$ & \\
\hline Giving clear directions & 1 & 2 & 3 & 4 & 5 & 1 & 2 & 3 & 4 & 5 & 6 & 1 & & $6+$ \\
\hline Presenting awards & 1 & 2 & 3 & 4 & 5 & 1 & 2 & 3 & 4 & 5 & 6 & 1 & $2-34-5$ & \\
\hline Leading an activity & 1 & 2 & 3 & 4 & 5 & 1 & 2 & 3 & 4 & 5 & 6 & 1 & $2-34-5$ & \\
\hline Setting priorities & 1 & 2 & 3 & 4 & 5 & 1 & 2 & 3 & 4 & 5 & 6 & 1 & $2-34-5$ & $6+$ \\
\hline Professional dress & 1 & 2 & 3 & 4 & 5 & 1 & 2 & 3 & 4 & 5 & 6 & 1 & $2-34-5$ & $6+$ \\
\hline Solving problems & 1 & 2 & 3 & 4 & 5 & 1 & 2 & 3 & 4 & 5 & 6 & 1 & \begin{tabular}{|l|l|}
$2-3$ & $4-5$ \\
\end{tabular} & $6+$ \\
\hline
\end{tabular}




\begin{tabular}{|c|c|c|c|c|c|c|c|c|c|c|c|c|c|c|c|}
\hline \multirow[t]{2}{*}{ Skill } & \multicolumn{5}{|c|}{$\begin{array}{c}\text { Where } \\
\text { Where do you } \\
\text { teach the skill? } \\
\text { (Circle all that apply) }\end{array}$} & \multicolumn{6}{|c|}{$\begin{array}{l}\text { Importance } \\
\text { How important is it to } \\
\text { teach this skill? }\end{array}$} & \multicolumn{4}{|c|}{$\begin{array}{l}\text { Frequency } \\
\text { How often do } \\
\text { you teach the } \\
\text { skill? }\end{array}$} \\
\hline & \begin{tabular}{c|}
$E$ \\
0 \\
0 \\
0 \\
0 \\
$\mathbb{0}$ \\
\end{tabular} & 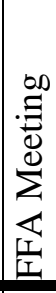 & 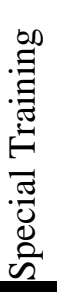 & $\begin{array}{l} \\
\mathscr{\Xi} \\
\tilde{\Xi} \\
\tilde{0} \\
\tilde{\Xi} \\
\tilde{\Xi}\end{array}$ & 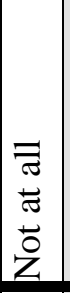 & 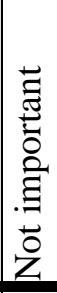 & & & & & 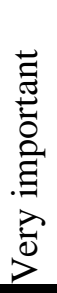 & 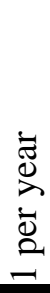 & 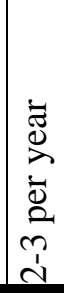 & 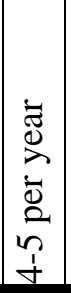 & 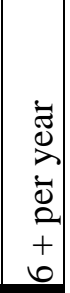 \\
\hline Clarifying personal value & 1 & 2 & 3 & 4 & 5 & 1 & 2 & 3 & 4 & 5 & 6 & 1 & $2-3$ & $4-5$ & $6+$ \\
\hline $\begin{array}{l}\text { Facilitating a meeting or } \\
\text { discussion }\end{array}$ & 1 & 2 & 3 & 4 & 5 & 1 & 2 & 3 & 4 & 5 & 6 & 1 & $2-3$ & $4-5$ & $6+$ \\
\hline Utilizing situational leadership & 1 & 2 & 3 & 4 & 5 & 1 & 2 & 3 & 4 & 5 & 6 & 1 & $2-3$ & $4-5$ & $6+$ \\
\hline Setting personal or team goals & 1 & 2 & 3 & 4 & 5 & 1 & 2 & 3 & 4 & 5 & 6 & 1 & $2-3$ & $4-5$ & $6+$ \\
\hline Writing a workshop & 1 & 2 & 3 & 4 & 5 & 1 & 2 & 3 & 4 & 5 & 6 & 1 & $2-3$ & $4-5$ & $6+$ \\
\hline Developing a program of work & 1 & 2 & 3 & 4 & 5 & 1 & 2 & 3 & 4 & 5 & 6 & 1 & $2-3$ & $4-5$ & $6+$ \\
\hline Relationship building & 1 & 2 & 3 & 4 & 5 & 1 & 2 & 3 & 4 & 5 & 6 & 1 & $2-3$ & $4-5$ & $6+$ \\
\hline Shaking hands the proper way & 1 & 2 & 3 & 4 & 5 & 1 & 2 & 3 & 4 & 5 & 6 & 1 & $2-3$ & $4-5$ & $6+$ \\
\hline Remembering names & 1 & 2 & 3 & 4 & 5 & 1 & 2 & 3 & 4 & 5 & 6 & 1 & $2-3$ & $4-5$ & $6+$ \\
\hline Using graphics & 1 & 2 & 3 & 4 & 5 & 1 & 2 & 3 & 4 & 5 & 6 & 1 & $2-3$ & $4-5$ & $6+$ \\
\hline Managing stress & 1 & 2 & 3 & 4 & 5 & 1 & 2 & 3 & 4 & 5 & 6 & 1 & $2-3$ & $4-5$ & $6+$ \\
\hline $\begin{array}{l}\text { Establishing and maintaining } \\
\text { conversations }\end{array}$ & 1 & 2 & 3 & 4 & 5 & 1 & 2 & 3 & 4 & 5 & 6 & 1 & $2-3$ & $4-5$ & $6+$ \\
\hline Encouraging others & 1 & 2 & 3 & 4 & 5 & 1 & 2 & 3 & 4 & 5 & 6 & 1 & $2-3$ & $4-5$ & $6+$ \\
\hline Using a microphone effectively & 1 & 2 & 3 & 4 & 5 & 1 & 2 & 3 & 4 & 5 & 6 & 1 & $2-3$ & $4-5$ & $6+$ \\
\hline Accepting constructive criticism & 1 & 2 & 3 & 4 & 5 & 1 & 2 & 3 & 4 & 5 & 6 & 1 & $2-3$ & $4-5$ & $6+$ \\
\hline Utilizing proper travel etiquette & 1 & 2 & 3 & 4 & 5 & 1 & 2 & 3 & 4 & 5 & 6 & 1 & $2-3$ & $4-5$ & $6+$ \\
\hline Using proper dining etiquette & 1 & 2 & 3 & 4 & 5 & 1 & 2 & 3 & 4 & 5 & 6 & 1 & $2-3$ & $4-5$ & $6+$ \\
\hline Delivering a speech & 1 & 2 & 3 & 4 & 5 & 1 & 2 & 3 & 4 & 5 & 6 & 1 & $2-3$ & $4-5$ & $6+$ \\
\hline Creating welcoming remarks & 1 & 2 & 3 & 4 & 5 & 1 & 2 & 3 & 4 & 5 & 6 & 1 & $2-3$ & $4-5$ & $6+$ \\
\hline Writing a speech & 1 & 2 & 3 & 4 & 5 & 1 & 2 & 3 & 4 & 5 & 6 & 1 & $2-3$ & $4-5$ & $6+$ \\
\hline Writing thank you letters & 1 & 2 & 3 & 4 & 5 & 1 & 2 & 3 & 4 & 5 & 6 & 1 & $2-3$ & $4-5$ & $6+$ \\
\hline $\begin{array}{l}\text { Practicing proper parliamentary } \\
\text { procedure }\end{array}$ & 1 & 2 & 3 & 4 & 5 & 1 & 2 & 3 & 4 & 5 & 6 & 1 & & & $6+$ \\
\hline
\end{tabular}




\begin{tabular}{|c|c|c|c|c|c|c|c|c|c|c|c|c|c|c|c|}
\hline \multirow[t]{2}{*}{ Skill } & \multicolumn{5}{|c|}{$\begin{array}{c}\text { Where } \\
\text { Where do you } \\
\text { teach the skill? } \\
\text { (Circle all that apply) }\end{array}$} & \multicolumn{6}{|c|}{$\begin{array}{l}\text { Importance } \\
\text { How important is it to } \\
\text { teach this skill? }\end{array}$} & \multicolumn{4}{|c|}{$\begin{array}{l}\text { Frequency } \\
\text { How often do } \\
\text { you teach the } \\
\text { skill? }\end{array}$} \\
\hline & 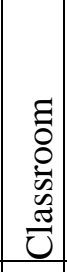 & 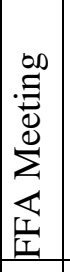 & 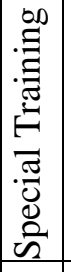 & $\begin{array}{l}\tilde{\Xi} \\
\tilde{\Xi} \\
\tilde{0} \\
\ddot{\Xi} \\
\tilde{\Xi}\end{array}$ & 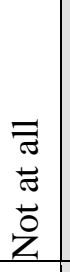 & 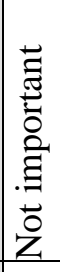 & & & & & 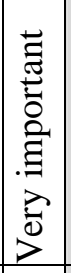 & 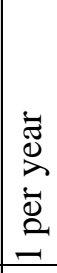 & 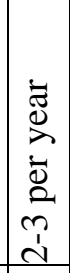 & 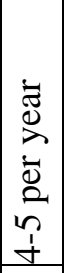 & 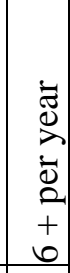 \\
\hline Running an effective meeting & 1 & 2 & 3 & 4 & 5 & 1 & 2 & 3 & 4 & 5 & 6 & 1 & $2-3$ & $4-5$ & $6+$ \\
\hline Writing business letters & 1 & 2 & 3 & 4 & 5 & 1 & 2 & 3 & 4 & 5 & 6 & 1 & $2-3$ & $4-5$ & $6+$ \\
\hline $\begin{array}{l}\text { Utilizing effective telephone } \\
\text { etiquette }\end{array}$ & 1 & 2 & 3 & 4 & 5 & 1 & 2 & 3 & 4 & 5 & 6 & 1 & $2-3$ & $4-5$ & $6+$ \\
\hline $\begin{array}{l}\text { Delegating so that the work gets } \\
\text { done }\end{array}$ & 1 & 2 & 3 & 4 & 5 & 1 & 2 & 3 & 4 & 5 & 6 & 1 & $2-3$ & $4-5$ & $6+$ \\
\hline Managing your life & 1 & 2 & 3 & 4 & 5 & 1 & 2 & 3 & 4 & 5 & 6 & 1 & $2-3$ & $4-5$ & $6+$ \\
\hline Using the internet & 1 & 2 & 3 & 4 & 5 & 1 & 2 & 3 & 4 & 5 & 6 & 1 & $2-3$ & $4-5$ & $6+$ \\
\hline $\begin{array}{l}\text { Using audio-visual equipment in } \\
\text { your presentations }\end{array}$ & 1 & 2 & 3 & 4 & 5 & 1 & 2 & 3 & 4 & 5 & 6 & 1 & $2-3$ & $4-5$ & $6+$ \\
\hline Taking great photographs & 1 & 2 & 3 & 4 & 5 & 1 & 2 & 3 & 4 & 5 & 6 & 1 & $2-3$ & $4-5$ & $6+$ \\
\hline Creating an awesome scrapbook & 1 & 2 & 3 & 4 & 5 & 1 & 2 & 3 & 4 & 5 & 6 & 1 & $2-3$ & $4-5$ & $6+$ \\
\hline $\begin{array}{l}\text { Developing and delivering } \\
\text { powerful key messages for your } \\
\text { chapter and department }\end{array}$ & 1 & 2 & 3 & 4 & 5 & 1 & 2 & 3 & 4 & 5 & 6 & 1 & $2-3$ & $4-5$ & $6+$ \\
\hline Designing attractive web pages & 1 & 2 & 3 & 4 & 5 & 1 & 2 & 3 & 4 & 5 & 6 & 1 & $2-3$ & $4-5$ & $6+$ \\
\hline $\begin{array}{l}\text { Creating partnerships with } \\
\text { community and industry leaders }\end{array}$ & 1 & 2 & 3 & 4 & 5 & 1 & 2 & 3 & 4 & 5 & 6 & 1 & $2-3$ & $4-5$ & $6+$ \\
\hline Creating a budget & 1 & 2 & 3 & 4 & 5 & 1 & 2 & 3 & 4 & 5 & 6 & 1 & $2-3$ & $4-5$ & $6+$ \\
\hline Networking & 1 & 2 & 3 & 4 & 5 & 1 & 2 & 3 & 4 & 5 & 6 & 1 & $2-3$ & $4-5$ & $6+$ \\
\hline How to build a powerful team & 1 & 2 & 3 & 4 & 5 & 1 & 2 & 3 & 4 & 5 & 6 & 1 & $2-3$ & $4-5$ & $6+$ \\
\hline Writing committee reports & 1 & 2 & 3 & 4 & 5 & 1 & 2 & 3 & 4 & 5 & 6 & 1 & $2-3$ & $4-5$ & $6+$ \\
\hline Managing your time effectively & 1 & 2 & 3 & 4 & 5 & 1 & 2 & 3 & 4 & 5 & 6 & 1 & $2-3$ & $4-5$ & $6+$ \\
\hline $\begin{array}{l}\text { Creating PowerPoint } \\
\text { presentations }\end{array}$ & 1 & 2 & 3 & 4 & 5 & 1 & 2 & 3 & 4 & 5 & 6 & 1 & $2-3$ & $4-5$ & $6+$ \\
\hline Running an effective meeting & 1 & 2 & 3 & 4 & 5 & 1 & 2 & 3 & 4 & 5 & 6 & 1 & $2-3$ & $4-5$ & $6+$ \\
\hline
\end{tabular}




\begin{tabular}{|c|c|c|c|c|c|c|c|c|c|c|c|c|c|c|c|}
\hline \multirow[t]{2}{*}{ Skill } & \multicolumn{5}{|c|}{$\begin{array}{c}\text { Where } \\
\text { Where do you } \\
\text { teach the skill? } \\
\text { (Circle all that apply) }\end{array}$} & \multicolumn{6}{|c|}{$\begin{array}{l}\text { Importance } \\
\text { How important is it to } \\
\text { teach this skill? }\end{array}$} & \multicolumn{4}{|c|}{$\begin{array}{l}\text { Frequency } \\
\text { How often do } \\
\text { you teach the } \\
\text { skill? }\end{array}$} \\
\hline & 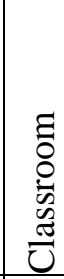 & 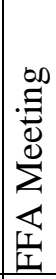 & 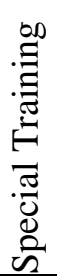 & $\begin{array}{l}\mathscr{0} \\
\tilde{0} \\
\tilde{0} \\
\tilde{0} \\
\tilde{\Xi} \\
0\end{array}$ & 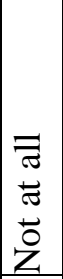 & 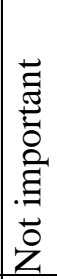 & & & & & 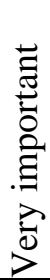 & 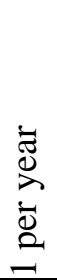 & 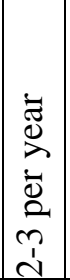 & 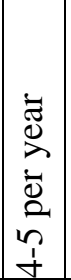 & 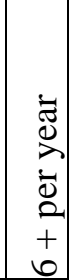 \\
\hline $\begin{array}{l}\text { Creating executive meetings that } \\
\text { your fellow officers will not } \\
\text { want to miss }\end{array}$ & 1 & 2 & 3 & 4 & 5 & 1 & 2 & 3 & 4 & 5 & 6 & 1 & $2-3$ & $4-5$ & $6+$ \\
\hline Being responsible & 1 & 2 & 3 & 4 & 5 & 1 & 2 & 3 & 4 & 5 & 6 & 1 & $2-3$ & $4-5$ & $6+$ \\
\hline Motivating members & 1 & 2 & 3 & 4 & 5 & 1 & 2 & 3 & 4 & 5 & 6 & 1 & $2-3$ & $4-5$ & $6+$ \\
\hline $\begin{array}{l}\text { Writing team or individual } \\
\text { mission statements }\end{array}$ & 1 & 2 & 3 & 4 & 5 & 1 & 2 & 3 & 4 & 5 & 6 & 1 & $2-3$ & $4-5$ & $6+$ \\
\hline $\begin{array}{l}\text { Dealing with difficult members } \\
\text { at your meetings }\end{array}$ & 1 & 2 & 3 & 4 & 5 & 1 & 2 & 3 & 4 & 5 & 6 & 1 & $2-3$ & $4-5$ & $6+$ \\
\hline Improving self confidence & 1 & 2 & 3 & 4 & 5 & 1 & 2 & 3 & 4 & 5 & 6 & 1 & $2-3$ & $4-5$ & $6+$ \\
\hline Creating a great first impression & 1 & 2 & 3 & 4 & 5 & 1 & 2 & 3 & 4 & 5 & 6 & 1 & $2-3$ & $4-5$ & $6+$ \\
\hline Presenting powerful ceremonies & 1 & 2 & 3 & 4 & 5 & 1 & 2 & 3 & 4 & 5 & 6 & 1 & $2-3$ & $4-5$ & $6+$ \\
\hline $\begin{array}{l}\text { Expressing your opinion so that } \\
\text { others listen }\end{array}$ & 1 & 2 & 3 & 4 & 5 & 1 & 2 & 3 & 4 & 5 & 6 & 1 & $2-3$ & $4-5$ & $6+$ \\
\hline Creating super slide shows & 1 & 2 & 3 & 4 & 5 & 1 & 2 & 3 & 4 & 5 & 6 & 1 & $2-3$ & $4-5$ & $6+$ \\
\hline Writing news releases & 1 & 2 & 3 & 4 & 5 & 1 & 2 & 3 & 4 & 5 & 6 & 1 & $2-3$ & $4-5$ & $6+$ \\
\hline $\begin{array}{l}\text { Getting local newspapers to } \\
\text { publish your news releases }\end{array}$ & 1 & 2 & 3 & 4 & 5 & 1 & 2 & 3 & 4 & 5 & 6 & 1 & $2-3$ & $4-5$ & $6+$ \\
\hline $\begin{array}{l}\text { Being a role model in your } \\
\text { chapter }\end{array}$ & 1 & 2 & 3 & 4 & 5 & 1 & 2 & 3 & 4 & 5 & 6 & 1 & $2-3$ & $4-5$ & $6+$ \\
\hline Opportunities in the FFA & 1 & 2 & 3 & 4 & 5 & 1 & 2 & 3 & 4 & 5 & 6 & 1 & $2-3$ & $4-5$ & $6+$ \\
\hline Organizational structure & 1 & 2 & 3 & 4 & 5 & 1 & 2 & 3 & 4 & 5 & 6 & 1 & $2-3$ & $4-5$ & $6+$ \\
\hline $\begin{array}{l}\text { Characteristics of an effective } \\
\text { team player }\end{array}$ & 1 & 2 & 3 & 4 & 5 & 1 & 2 & 3 & 4 & 5 & 6 & 1 & $2-3$ & $4-5$ & $6+$ \\
\hline Types and uses of power & 1 & 2 & 3 & 4 & 5 & 1 & 2 & 3 & 4 & 5 & 6 & 1 & $2-3$ & $4-5$ & $6+$ \\
\hline Leadership levels & 1 & 2 & 3 & 4 & 5 & 1 & 2 & 3 & 4 & 5 & 6 & 1 & $2-3$ & & $6+$ \\
\hline
\end{tabular}




\begin{tabular}{|c|c|c|c|c|c|c|c|c|c|c|c|c|c|c|c|}
\hline \multirow[t]{2}{*}{ Skill } & \multicolumn{5}{|c|}{\begin{tabular}{|c} 
Where \\
Where do you \\
teach the skill? \\
(Circle all that apply)
\end{tabular}} & \multicolumn{6}{|c|}{$\begin{array}{l}\text { Importance } \\
\text { How important is it to } \\
\text { teach this skill? }\end{array}$} & \multicolumn{4}{|c|}{$\begin{array}{l}\text { Frequency } \\
\text { How often do } \\
\text { you teach the } \\
\text { skill? }\end{array}$} \\
\hline & 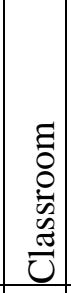 & 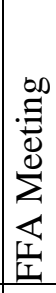 & 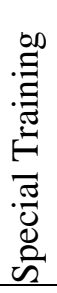 & $\begin{array}{l} \\
\mathscr{\Xi} \\
\tilde{\sigma} \\
\tilde{0} \\
\tilde{y} \\
\tilde{\Xi}\end{array}$ & 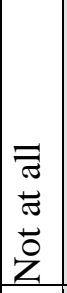 & 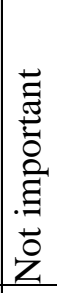 & & & & & 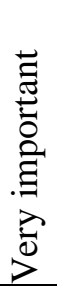 & 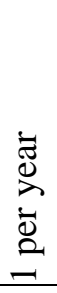 & 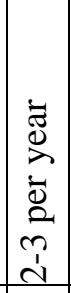 & 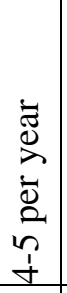 & 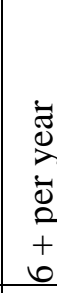 \\
\hline Leadership styles & 1 & 2 & 3 & 4 & 5 & 1 & 2 & 3 & 4 & 5 & 6 & 1 & $2-3$ & $4-5$ & $6+$ \\
\hline Qualities of an influential leader & 1 & 2 & 3 & 4 & 5 & 1 & 2 & 3 & 4 & 5 & 6 & 1 & $2-3$ & $4-5$ & $6+$ \\
\hline Learning styles & 1 & 2 & 3 & 4 & 5 & 1 & 2 & 3 & 4 & 5 & 6 & 1 & $2-3$ & $4-5$ & $6+$ \\
\hline Ag issues & 1 & 2 & 3 & 4 & 5 & 1 & 2 & 3 & 4 & 5 & 6 & 1 & $2-3$ & $4-5$ & $6+$ \\
\hline Ag Ed Issues & 1 & 2 & 3 & 4 & 5 & 1 & 2 & 3 & 4 & 5 & 6 & 1 & $2-3$ & $4-5$ & $6+$ \\
\hline $\begin{array}{l}\text { Great meeting activities-mixers, } \\
\text { icebreakers, energizers, etc. }\end{array}$ & 1 & 2 & 3 & 4 & 5 & 1 & 2 & 3 & 4 & 5 & 6 & 1 & $2-3$ & $4-5$ & $6+$ \\
\hline Group dynamics & 1 & 2 & 3 & 4 & 5 & 1 & 2 & 3 & 4 & 5 & 6 & 1 & $2-3$ & $4-5$ & $6+$ \\
\hline Enhancing your creativity & 1 & 2 & 3 & 4 & 5 & 1 & 2 & 3 & 4 & 5 & 6 & 1 & $2-3$ & $4-5$ & $6+$ \\
\hline Keys to personal success & 1 & 2 & 3 & 4 & 5 & 1 & 2 & 3 & 4 & 5 & 6 & 1 & $2-3$ & $4-5$ & $6+$ \\
\hline Banquet ideas that work & 1 & 2 & 3 & 4 & 5 & 1 & 2 & 3 & 4 & 5 & 6 & 1 & $2-3$ & $4-5$ & $6+$ \\
\hline Personal hygiene and attire & 1 & 2 & 3 & 4 & 5 & 1 & 2 & 3 & 4 & 5 & 6 & 1 & $2-3$ & $4-5$ & $6+$ \\
\hline Maintaining a positive attitude & 1 & 2 & 3 & 4 & 5 & 1 & 2 & 3 & 4 & 5 & 6 & 1 & $2-3$ & $4-5$ & $6+$ \\
\hline Humility & 1 & 2 & 3 & 4 & 5 & 1 & 2 & 3 & 4 & 5 & 6 & 1 & $2-3$ & $4-5$ & $6+$ \\
\hline Cooperation & 1 & 2 & 3 & 4 & 5 & 1 & 2 & 3 & 4 & 5 & 6 & 1 & $2-3$ & $4-5$ & $6+$ \\
\hline Flexibility & 1 & 2 & 3 & 4 & 5 & 1 & 2 & 3 & 4 & 5 & 6 & 1 & $2-3$ & $4-5$ & $6+$ \\
\hline Commitment & 1 & 2 & 3 & 4 & 5 & 1 & 2 & 3 & 4 & 5 & 6 & 1 & $2-3$ & $4-5$ & $6+$ \\
\hline Integrity & 1 & 2 & 3 & 4 & 5 & 1 & 2 & 3 & 4 & 5 & 6 & 1 & $2-3$ & $4-5$ & $6+$ \\
\hline Risk-taking & 1 & 2 & 3 & 4 & 5 & 1 & 2 & 3 & 4 & 5 & 6 & 1 & $2-3$ & $4-5$ & $6+$ \\
\hline Passion & 1 & 2 & 3 & 4 & 5 & 1 & 2 & 3 & 4 & 5 & 6 & 1 & $2-3$ & $4-5$ & $6+$ \\
\hline Lifelong learning & 1 & 2 & 3 & 4 & 5 & 1 & 2 & 3 & 4 & 5 & 6 & 1 & $2-3$ & $4-5$ & $6+$ \\
\hline Wisdom & 1 & 2 & 3 & 4 & 5 & 1 & 2 & 3 & 4 & 5 & 6 & 1 & $2-3$ & $4-5$ & $6+$ \\
\hline Ethical leadership & 1 & 2 & 3 & 4 & 5 & 1 & 2 & 3 & 4 & 5 & 6 & 1 & $2-3$ & $4-5$ & $6+$ \\
\hline Forgiveness & 1 & 2 & 3 & 4 & 5 & 1 & 2 & 3 & 4 & 5 & 6 & 1 & $2-3$ & $4-5$ & $6+$ \\
\hline Gratitude & 1 & 2 & 3 & 4 & 5 & 1 & 2 & 3 & 4 & 5 & 6 & 1 & $2-3$ & $4-5$ & $6+$ \\
\hline Acceptance of others & 1 & 2 & 3 & 4 & 5 & 1 & 2 & 3 & 4 & 5 & 6 & 1 & $2-3$ & $4-5$ & $6+$ \\
\hline Teamwork & 1 & 2 & 3 & 4 & 5 & 1 & 2 & 3 & 4 & 5 & 6 & 1 & $2-3$ & $4-5$ & $6+$ \\
\hline
\end{tabular}


Please answer the following questions by writing your response in the appropriate blank.

1. What is the student enrollment of your high school?

2. What is the student enrollment in your agricultural science program?

3. What is the FFA membership of your chapter?

4. How many agricultural science teachers/FFA advisors are in your program?

5. How many years teaching experience do you have?

6. If you teach in a multiple teacher department please indicate the number of years teaching experience of each teacher.

Teacher 1

Teacher 2

Teacher 3

Teacher 4

Teacher 5

Teacher 6

Please list additional teachers in the space to the right.

7. Who assists you in providing leadership training? (Check all that apply)

No assistance

Chapter FFA Officer(s)

Past Chapter FFA Officer(s)

Regional/District FFA Officer(s)

State FFA Officer(s)

Advisory Committee Member(s)

Chapter Alumni

Other (please specify) 


\section{Comments:}

If you have questions about the survey, please contact me at: ntaylor7@mix.wvu.edu call (304 293-4832 x 4482

Please return survey in enclosed postage paid envelope or send to: Nathan Taylor

Agricultural Education

P.O. Box 6108

Morgantown, WV 26506

Thank you for taking the time to camplete

this surwey. 
APPENDIX B

Cover Letter 
January 24, 2006

«Sal»

«School» «FFA_Chapter»

«add»

«city», «State1» «zip»

Dear Agricultural Educator:

The agricultural education profession takes pride in its ability to develop leadership skills in its members. The variety of experiences available to FFA members is countless. Activities available at the chapter, state, and national levels provides opportunities for members to develop new skills and abilities as leaders.

The purpose of this research study is to determine where leadership skills are taught, the importance of various topics, and the frequency with which topics are taught. The results of this study will be used to prepare a thesis to partially fulfill the requirements for a Master of Science Degree in Agricultural Education. By determining where skills are taught and what topics are important in leadership development agricultural science teachers and FFA advisors could better prepare their students to become future leaders.

Participation in this research study is completely voluntary and all information you provide will be held as confidential as possible. Your response to the survey will be critical to the success of the study and will only take a few minutes of your time to complete. You may skip any question you are not comfortable answering. You will notice a code number at the top left of the return envelope. This code will be used to identify non-respondents for follow-up and will be destroyed before the data are analyzed. Survey results will be reported in a summary format and individual responses will not be identifiable.

Place the completed questionnaire in the enclosed postage-paid self-addressed return envelope and drop it in the mail. Please return your completed questionnaire before February 8, 2006. Thank you in advance for your assistance with this research effort. We sincerely appreciate your time and effort .

Sincerely,

Nathan Taylor

Graduate Student
Deborah A. Boone, Ph.D. Assistant Professor 
APPENDIX C

Follow-Up Cover Letter 
February 14, 2006

«Sal»

«School» «FFA_Chapter»

«add»

«city», «State1» «zip»

Dear Agricultural Educator:

At the $78^{\text {th }}$ National FFA Convention your chapter was recognized through the National Chapter Award Program as being one of the outstanding chapters in the country. This award reflects your hard work as an agricultural educator in fulfilling the FFA Mission of developing your students' potential for "Premier Leadership, Personal Growth, and Career Success.”

Because of the recognition that you and your chapter have earned we are asking you to help us in determining leadership skills that are vital to developing "Premier Leadership" in local chapters. Your chapter was randomly selected from over 650 chapters that were recognized through the National Chapter Award Program. Your responses not only reflect your chapter but many others in this distinguished group. Your response is vital to the success of this project.

On January 20, we sent you a questionnaire about leadership development. As of today, we have not received your reply. We have enclosed a second copy of the survey and hope you will take the time to complete and return. If you have already returned the first survey there is no need to complete this one, we sincerely appreciate your participation.

The purpose of this research study is to determine where leadership skills are taught, the importance of various topics, and the frequency with which topics are taught. The results of this study will be used to prepare a thesis to partially fulfill the requirements for a Master of Science Degree in Agricultural Education. By determining where skills are taught and what topics are important in leadership development agricultural science teachers and FFA advisors could better prepare their students to become future leaders.

Participation in this research study is completely voluntary and all information you provide will be held as confidential as possible. Your response to the survey will be critical to the success of the study, and will only take a few minutes of your time to complete. You may skip any question you are not comfortable answering. You will notice a code number at the top left of the return envelope. This code will be used to identify non-respondents for follow-up and will be destroyed before the data are analyzed. Survey results will be reported in a summary format and individual responses will not be identifiable.

Place the completed questionnaire in the enclosed postage-paid self-addressed return envelope and drop in the mail. Please return your completed questionnaire before February 28, 2006. Thank you in advance for your assistance with this research effort. We sincerely appreciate your time and effort.

Sincerely,

Nathan Taylor

Graduate Student
Deborah A. Boone, Ph.D.

Assistant Professor 


\section{VITA}

\section{Nathan Taylor}

July 2001-July 2002

President

West Virginia FFA Association

October 2003

American FFA Degree

May 2005

Bachelor of Science

Agricultural \& Environmental Education

West Virginia University

Morgantown, WV

May 2006

Master of Science

Agricultural \& Environmental Education

West Virginia University

Morgantown, WV 